\title{
A ReVIEW OF NON-RENEWABLE ENERGY OPTIONS IN ILLINOIS
}

\author{
by \\ L.Barnie Agyarko and G.Ali Mansoori* \\ University of Illinois at Chicago, Chicago, IL 60607, USA
}

\section{BIOGRAPHICAL NOTES:}

L. Barnie Agyarko received his BSc and MSc degrees, both, in chemical engineering from the University of Illinois at Chicago. During his undergraduate studies and prior to his master's degree, he interned at the Argonne National Laboratory, in Argonne, Illinois while developing novel materials for high energy density batteries for specialty and commercial applications. As part of his MSc degree in engineering training, he worked for the Gas Technology Institute in Des Plaines, Illinois working on natural gas processing. He has publications on both fuels processing and renewable energy utilization.

G. Ali Mansoori is a professor of chemical and bio engineering at UIC. He has published extensively in the areas of energy sources, fossil fuels, nanobiotechnology, statistical mechanics, and thermodynamics. He is the author of eight books including "C7+ Fraction Characterization", "Diamondoid Molecules", "Principles of Nanotechnology" and over 500 referred papers. He has been a consultant and lecturer to several energy-related organizations. He has served as editor and in editorial boards of several energy- and nanotechnology related journals. Dr. Mansoori has organized and chaired numerous energy- and nanotechnology related conferences and symposia, both on national and international arena. For his research and educational achievements, Dr. Mansoori has received numerous recognitions and awards.

ABSTRACT: The State of Illinois has the largest non-renewable (fossil) energy reserves among all the states in the United States. We report our studies on coal, oil and gas energy resources, conversions, consumptions and carbon dioxide sequestration advances in Illinois from the point of view of sustainability in energy and environmental. This includes reserves and characteristics of coal, oil and gas in the Illinois Basin, enhanced oil recovery possibilities, coalbed-methane recovery, underground coal gasification possibilities, and natural gas production potential from the New Albany Shale through hydraulic fracturing, as well as the benefits and technological problems which may be encountered. We also analyze the present underground gas storage facilities and the benefits and potential for underground carbon dioxide storage options in Illinois. Considering that the major end-use version of energy in Illinois is electricity, we 
investigate the role of "Clean Air Act" on the future of "clean coal technology" fossil-fueled power plants in Illinois.

\section{KEYWORDS:}

Clean Air Act; clean coal technology; coal; fossil-fueled power plant, Illinois Basin, natural gas; New Albany Shale, petroleum; shale gas; underground coal gasification; hydraulic fracturing; carbon dioxide capture and sequestration.

*Corresponding author: $\underline{\text { mansoori@uic.edu }}$

\section{INTRODUCTION}

Here we report on coal, oil and gas energy resources and technologies available for Illinois to achieve its goal of non-renewable (fossil) energy sufficiency and cleaner environment. In 2009, Illinois having the $5^{\text {th }}$ largest population among the states in the United States also ranked $5^{\text {th }}$ state in total energy consumption with about $10^{18}$ calories, behind New York, Florida, California and Texas. Also, in the same year Illinois ranked $33^{\text {rd }}$ state in the United States in energy consumption per real dollar of GDP, estimated as 171,360 calories per US dollar (based on 2005 US dollar adjusted for inflation) which is about one half that of Indiana, Kentucky and West Virginia (US-EIA 2011). Presently Illinois depends mostly on non-renewable and nuclear energies to meet its energy needs, with most of the energy derived from coal and nuclear (USEIA 2011).

Non-renewable energy sources include coal, petroleum and natural gas which are natural resources that cannot be reproduced once depleted. The principal author of this report has a long history of educational and research experiences with non-renewable energy sources and related downstream processing's (Mansoori 1993; Mansoori 1998; Mansoori and Moradi 2000; Suwono, and Mansoori 1994, 1997, 2000, 2003, 2006; Lopes Barros de Araujo et al. 2012). In contrast, energy sources such as solar, wind, and biomass are considered renewable resources.

For over a century, coal has become the bedrock of Illinois energy source, feeding its electric power plants to generate electricity. Illinois has the largest overall as well as the largest strippable bituminous coal reserves in the United States. However, the state cannot use much of 
its coal because of unfavorable geologic condition and surface development, coupled with the high sulfur content of Illinois coal that its emissions wreaks havoc on the environment (US-EIA 1994). This situation has caused a decline in the state's annual coal production which current estimate is 30 million metric tons per year. In 2009, Illinois expenditure on coal was about 1.74 billion dollars and ranked $8^{\text {th }}$ in coal production in the nation, behind Texas, Indiana, Montana, Pennsylvania, Kentucky, West Virginia and Wyoming (US-EIA 2011). For this reason, the state is searching for clean coal technologies that will maximize the use of indigenous coal to halt these imports, while restoring the level of employment opportunities that used to be in the coal industry.

One method to curb emissions from coal-fired power plants is through a demandresponse program, which requires consumers to use less energy, and hence construction of fewer coal-fired power plants. Demand-response means consumers' ability to reduce electricity usage at their places, as a result of high wholesale prices of electricity or the reliability of the electric grid being in jeopardy during peak load periods (US-DOE 2006). An alternative approach to reduce emissions from coal-fired power plants is through increased energy efficiency and conservation programs. This means judicious use of energy for equipment, buildings or products without altering the quality of their services. Among the various options being considered for emission control in Illinois, energy efficiency offers the lowest cost per energy savings ( $\$ 0$ to $\$ 50.00$ per megawatt hour) (Wernau 2011). Additionally, Illinois policy makers could implement the newly unveiled US Environmental Protection Agency (US-EPA) measures to force some of the older coal-fired power plants to retire and curb the emissions.

Illinois is not a major producer, but consumes a lot of petroleum and natural gas. As a result, the state imports crude oil from Canada, while natural gas is purchased from overseas through the U.S. Gulf Coast, the U.S midcontinent regions, Western Canada, Colorado and Wyoming. In 2009, Illinois consumed about 240 million barrels of crude oil at a cost of about 20.5 billion dollars, representing $50.6 \%$ of the total energy expenditure by the state (US-EIA 2011). In the same year, Illinois consumption of natural gas totaled $26.79 \times 10^{9}$ standard cubic meters at the cost of 7.62 billion dollars (US-EIA 2011). Illinois is a major transportation hub for crude oil and natural gas distribution throughout North America, due to its central location and pipeline infrastructure. The 2010 energy industry economic output from the pipeline transportation sector was approximately 662.6 million dollars (Lewis and Bergeron 2010). This 
revenue was based on services offered by the oil and gas transportation hubs, employment, as well as taxes paid by the pipeline companies to the state.

To reduce its oil and natural gas imports, Illinois legislators are debating on how to tap into the vast resource of shale gas located in the Illinois Basin. With abundance of cheap natural gas in the state, Illinois could replace some of its coal-fired power plants with natural gas-fired power plants to reduce emissions. Additionally, Illinois is planning the infrastructure for carbon dioxide capture and sequestration from its new generation coal-fired power plants. The carbon dioxide could be used for enhanced oil and coal-bed gas recovery in the Illinois Basin to boost the state's petroleum and natural gas production.

In Table 1 we summarize the consumption and production of fossil fuels in Illinois. The rest of this paper consists of five sections. The first three sections are devoted to coal, oil and gas resources, in Illinois, respectively. The fourth section is on carbon dioxide capture and sequestration in Illinois. In the final concluding section we analyze the non-renewable energy options for Illinois with the goal of sustainability in energy and environment.

Table 1. Illinois non-renewable energy profile in 2009 as compared with the other states while standing the $5^{\text {th }}$ in population among all the states in the United States (US-EIA 2011)

\begin{tabular}{|l|l|c|}
\hline Subject & Amount & US Rank \\
\hline Total energy consumption & $10^{18}$ Calories & 5 \\
\hline Coal consumption & $51.93 \times 10^{6}$ metric tons & 5 \\
\hline Coal production & $30.86 \times 10^{6}$ metric tons & 8 \\
\hline Petroleum consumption & 240 million barrels & 7 \\
\hline Petroleum production & 9.10 million barrels & 14 \\
\hline Natural gas consumption & $26.79 \times 10^{9}$ std. $\mathrm{m}^{3}$ & 6 \\
\hline Natural gas production & $40.90 \times 10^{6}$ std. $\mathrm{m}^{3}$ & 27 \\
\hline
\end{tabular}

\section{COAL}

The abundance of coal in Illinois makes it one of the cheapest sources of fuel for base load electric energy generation and possibly other uses in the state. In the U.S, Illinois has the largest overall, as well as the largest strippable bituminous coal reserves. As we mentioned in the 
introductory section, Illinois currently produces roughly 30 million tons of coal annually (IDCEO 2008). The total recoverable reserve (i.e. quantity of coal that can be recovered from existing coal reserves at reporting mines) is about 1.24 billion tons (IDCEO 2008). The total demonstrated Illinois reserve base is 104.2 billion tons (IDCEO 2010). This includes publicly available data on coal beds mapped and located underground with thicknesses considered technologically minable at the time of determinations. The reported total estimated recoverable reserve is 37.9 billion tons (IDCEO 2010). These include the coal in the demonstrated reserve base considered recoverable, excluding coal estimated to be unavailable due to land use restrictions or currently economically unattractive for mining after applying the recovery rate assumptions. Out of these estimated recoverable reserves, about 28 billion tons are exploitable by underground mining methods, and about 10 billion tons are exploitable through surface mining methods (IDCEO 2010).

But Illinois cannot use much of its indigenous coal, partly due to unfavorable geologic conditions and surface developments and partly due to the high sulfur content of the coal. This situation has forced several coal mines in the state to shutdown, affecting coal production after mid-1990 as shown in Figure 1. Currently power plant companies prefer using low sulfur content coal from other states to reduce gas clean-up cost and meet the minimum environmental regulations (U.S. EIA 1994). In 2008, Illinois imported $94 \%$ of the coal burned in its power plants at the cost of $\$ 1.49$ billion from states like Wyoming (Union of Concerned Scientist 2010). Most of this expenditure was offset by selling electricity to other states and by shipping about $\$ 800$ million worth of high sulfur content Illinois coal to states with less stringent environmental regulations, such as Indiana, Tennessee, Florida and Missouri. 


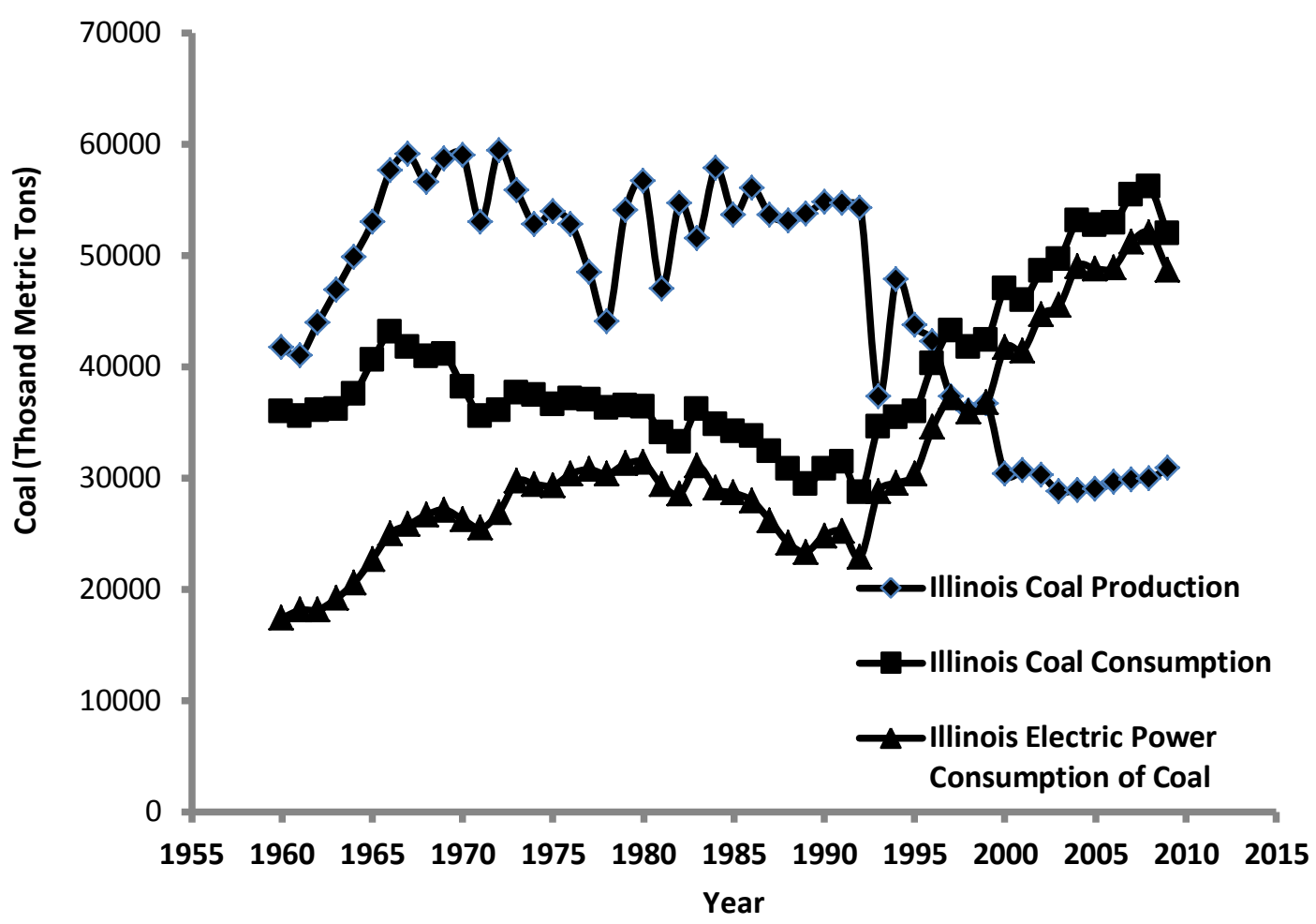

Figure 1. Profiles of coal production and consumption in Illinois (Data from U.S. IEA 2011)

In 2008, there were 21 coal-fired power plants in Illinois operated by eight utility companies, generating a total of $16,240 \mathrm{~mW}$ of electricity (IDCEO 2008). These included Midwest Generation EME, LLC (six plants), Dynegy Midwest Generation (five plants), AmerenEnergy Generating (four plants), Dominion Energy Services Company (one plant), AmerenEnergy Resources (two plants), Electric Energy, Inc (one plant), Springfield City Water, Light and Power Company (one plant) and Southern Illinois Power Cooperative (one plant) (IDCEO 2008).

Demand for electric energy usage can be categorized as base load, intermediate load and peak load. Base load electric energy demand in Illinois is met mostly by coal and nuclear power plants, with coal power representing $46 \%$ of electricity production in the state and nuclear 49.5\%. Base load power plants are typically larger (over $600 \mathrm{~mW}$ ) than intermediate and peak load power plants, comparatively more efficient and reliable, and can continuously produce lowcost electric energy (Cordaro 2008). On the other hand, intermediate and peak load power plants are designed to be smaller and quickly brought online to respond to electric power demand 
during peak periods. These plants usually require natural gas as the fuel or a combination of fuels to meet the various load demands.

Coal-fired plants generate electricity by burning pulverized coal mixed with very hot air to produce steam. The high pressure steam turns a turbine that drives an electric generator to produce electricity. But despite coal being the cheapest source of fuel, the State of Illinois faces a dilemma about its use, due to environmental concerns for air and water quality. These environmental concerns associated with the use of coal include, the release of significant levels of nitrogen oxides $(\mathrm{NO} x)$, sulfur oxides $(\mathrm{SO} x)$, particulate matter, carbon dioxide $\left(\mathrm{CO}_{2}\right)$ and mercury.

In 2009, the Illinois electric power industry ranked $8^{\text {th }}$ in both sulfur and nitrogen oxides (SOx and NOx) emissions in U.S., estimated to be 237,000 and 78,000 tons, respectively (U.S. EIA 2011). Currently, Illinois carbon dioxide footprint from the electric power industry ranks $6^{\text {th }}$ in the nation and is estimated at more than 90 million tons per year (see section 5). The Illinois Environmental Protection Agency (Illinois-EPA) estimated that the state's coal-fired power plants emit 3.5 tons of mercury every year (IDCEO 2008). The 2010 estimated emission of particulate matter (PM 10) in Illinois was 30,931 tons (IEPA 2011).

There are environmental concerns about green house effect due to carbon dioxide emissions, as well as health hazards posed by mercury, SOx, NOx, particulate matter, and contamination of aquifers by coal mine slurry injections. As a result, policymakers have passed a legislation that could curtail these pollutants with minimal financial burden on consumers. In this legislation, coal-fired power plant companies will have the option to decide between paying extra money for more efficient scrubbers and pollution control devices or have some of their plants closed as a means to reduce emissions (Wernau 2011). The implication of such a policy is that consumers could face more expensive energy supply. For this reason, policymakers are introducing some measures for energy usage and exploring other alternative energy sources that are cheaper and cleaner. These include the use of energy efficiency programs, demand-response, more natural gas plants, clean coal technologies, addition of generating capacity to ramp up underutilized generating plants, as well as biofuel, wind and solar energy utilization.

\subsection{The characteristics of Illinois Coal}


According to the Illinois State Museum (www.museum.state.il.us) Illinois coal occurs in seams (layers). These seams vary from less than 2 centimeters (.75 in.) to more than 4.5 meters (about $15 \mathrm{ft}$.) thick. Dozens of coal seams underlie Illinois. The major seams have been given names to identify them. The largest is the Herrin Coal, named for a Southern Illinois town in Williamson County. In 1868, geologists numbered the coal seams by age. Number one is the oldest. Springfield Coal is number 5 and Herrin Coal is number 6. The Springfield Coal seam averages 1.5 meters (about 5 feet) in thickness, while Herrin Coal seam averages 1.8 meters (about 6 feet). Because of the gradual down-warping of the basement rock, Illinois coal is near the surface in some areas and buried as deep as 365 meters in others (that's about 1,200 feet deep). Illinois coal has a high heating value, ranging from $6,111 \mathrm{kCal} / \mathrm{kg}$ in the northwestern part of the state to about $8,333 \mathrm{kCal} / \mathrm{kg}$ in the southeastern part of the state (IDCEO 2010). The ash content of Illinois coal may vary from place to place with an average ash content of about $10 \%$.

In Table 2, the characteristics of Illinois coal are reported. According to IDCEO (2010), the high sulfur content of Illinois coal beds is attributed to the character of the strata lying underneath the coal. Usually the coals overlain by marine strata have a sulfur content ranging from three to five percent. In certain non-marine areas when gray shale exceeds 20 feet in thickness above the coal, the sulfur content is less than $2.5 \%$, commonly averaging $1.5 \%$. In Illinois coal, as in other coals, sulfur exists in two forms: organic and pyritic. The organic sulfur content of Illinois coals varies from a minimum of about $0.4 \%$ to a maximum of about $5 \%$. Pyritic sulfur varies from nearly zero to as high as $5 \%$. Also the mean moisture content of Illinois coal is $10.5 \%$, while the mean fixed carbon content is $43.4 \%$ (Affolter and Hatch 2002).

Table 2. Characteristics of Illinois coal

\begin{tabular}{|l|l|}
\hline Organic sulfur $^{\text {a }}$ & $0.4-5 \%$ \\
\hline Pyritic sulfur $^{\text {a }}$ & $0-5 \%$ \\
\hline Mean moisture $^{\mathrm{a}}$ & $10.5 \%$ \\
\hline Mean fixed $^{\mathrm{a}}$ & $43.4 \%$ \\
\hline Average ash $^{\mathrm{b}}$ & $10 \%$ \\
\hline Heating value $^{\mathrm{b}}$ & $6,111 \mathrm{kCal} / \mathrm{kg}$ \\
\hline
\end{tabular}

Almost all the coal mined in Illinois is subject to cleaning at preparation plants, in order to reduce the sulfur content of the final product by as much as one-third. For detailed analysis 
and data on characterization of the quality of coals from the Illinois Basin see (Affolter and Hatch 2002).

\section{2. "Clean Air Act" and its impact on coal-fired power plants in Illinois}

The "Clean Air Act" of 1970 authorized the US Environmental Protection Agency (US-EPA) to set limits on how much of a pollutant can be released into the environment in the United States. The law permits individual states to have stronger, rather than weaker pollution control regulations. Under Phase I of the "Clean Air Act", power plants built after August 17, 1971 were subjected to New Source Performance Standards (air pollution emission standards), which allowed a maximum emission rate of $2.16 \mathrm{~kg} \mathrm{SO}_{2}$ per million $\mathrm{kCal}$ (IDCEO 2008). Also the Phase II of the "Clean Air Act" of 1970 required New Source Performance Standards to remove a certain percentage of $\mathrm{SO}_{2}$ from flue-gases by January 2000.

The 1970 "Clean Air Act” was later extended by amendments in 1977 and later in 1990. It authorized US-EPA to establish standards for a number of atmospheric pollutants, including sulfur dioxide $\left(\mathrm{SO}_{2}\right)$. The 1990 "Clean Air Act" Amendments encouraged the use of marketbased principles and other innovative approaches, such as emission banking and trading and performance-based standards. Furthermore, the 1990 Act provided a framework from which alternative clean fuels would be used by setting standards in the fleet and a California pilot program that could be met by the most cost-effective combination of fuels and technology. Additionally, the 1990 Act encouraged use of the following:

(i). Use of clean low-sulfur coal and natural gas, including innovative technologies to clean high-sulfur coal to reduce the acid rain.

(ii). Reduce energy waste and create sufficient market for clean fuels derived from agriculture and natural gas to cut reliance on oil imports by one million barrels per day.

(iii). Use innovative approaches and market-based principles, such as performance-based standards and emission banking and trading (IDCEO 2008) to reduce pollution.

As regards to the Clean Air Mercury Rule, Illinois opted for a more stringent one than the US-EPA's limit because it wanted to cut emissions from coal-fired power plants by an average of $90 \%$ by 2009 . For example, the Illinois mercury rule is expected to achieve over $90 \%$ of 
mercury reductions by 2015 , while federal rules only require a $78 \%$ by 2018 . Again, the Illinois mercury rule is expected to achieve between $65-80 \%$ reduction in sulfur dioxide by 2019 , on the other hand, the federal rule only requires 34\% reduction by 2019 (IDCEO 2008). These additional rules for reduction of pollutants by Illinois power plants have made the state a leader of power plants pollution control in the United States.

The "Clean Air Act" and its subsequent amendments in 1990 brought innovations into the energy industry in Illinois. In 2006, the Illinois' second largest utility company, Ameren Corporation, reached an agreement with the state to curb emissions of the three most harmful power plant pollutants: mercury, sulfur dioxide and nitrogen oxides (Environmental News Service 2006). To reach this goal, Ameren Corporation agreed to install $\$ 1.6$ billion in technology upgrades at seven of its power plants in central and Southern Illinois. This also was intended to enable the company to use more Illinois coal, which has higher sulfur content than coal from other regions.

In April 2007, the U.S. Supreme Court authorized the US-EPA to regulate carbon dioxide as a pollutant. According to the ruling of the U.S Supreme Court, US-EPA's reason for not regulating carbon dioxide was inadequate (IDCEO 2008). The result of this ruling has had tremendous repercussions on the power plant industry, including those in Illinois, because utility companies need to spend more money to meet the new regulations.

In 2008, the US government proposed the "Clean Air Interstate Rule" which was purported to cut pollution that spreads hundreds of miles and has enormous negative impacts on millions of Americans (Hawthorne 2010). However, the U.S. Court of Appeals for the District of Columbia ordered the US-EPA to revise the rule, after deciding that the agency had overstepped its authority. This court ruling allowed many utility companies to withdraw their investments in pollution control. However, in 2010, the US government revisited the "Clean Air Interstate Rule" by urging the US-EPA to reduce pollution in areas around coal-fired power plants and in states downwind, where air quality is degraded by sulfur dioxide and nitrogen oxide emissions.

On May 24, 2011, the US-EPA for the first time held a national debate in Chicago, on its proposed standards for setting federal new limits for mercury, arsenic, lead, hydrochloric acid and other hazardous air pollutants (Learner \& Rowe 2011). Among the two key safety rules the 
US-EPA proposed under the Clean Air Act to protect public health and the environment were the Toxics Rule and the Clean Air Transport Rule.

On December 21, 2011, the US-EPA unveiled its final rule on the new Toxic rules. There were no changes to the original proposals. However, there was a presidential memorandum attached to the new rules. This memorandum authorized the US-EPA to use the law to give energy companies more time beyond the three-year deadline for equipment installation or shut down old plants if they refuse (Drajem 2011). The US-EPA rule on powerplant emissions for sulfur dioxide and nitrogen oxides that crosses state borders was set to take effect in 2012; however the rule is being challenged by energy companies in court and is likely to face challenges in the U.S Congress as well (Drajem 2011).

In January 2012, The U.S. Court of Appeals in the District of Columbia suspended the Cross-State Air Pollution Rule some days before it could be implemented, a decision that gave impetus to the claims of a group of power plant companies and states that the new rule is too austere and illegal. In April 2012, the court began a hearing on those challenges leveled against the U.S. Environmental Protection Agency regulations. According to legal fillings at the court, the challengers raised at least ten questions about the legality of the new US-EPA rule. Among the key questions was the argument by the electric power companies that the US-EPA failed to justify the pollution limits of the new rules. Also a group of 15 upwind states questioned as to whether US-EPA did not violate the law by not allowing them to develop their own plans for reducing emissions before the new rule was implemented. But not all power plant companies opposed the new rule, especially the owners of nuclear and natural gas power plants. These electric power companies which include Exelon Corporation and Calpine Corporation have linked up with nine downwind states in filing briefs in support of the new rule. Additionally, several environmental and public health groups are supporting the agency (Dow Jones Newswires 2012).

This current turnaround of events is forcing several utility companies in Illinois to shutdown and phase out some of their aging power plants. For example, some utility companies that own coal-fired electric power plants in the Chicago area are facing federal lawsuits, alleging that the companies failed to install pollution control devices, while keeping the plants operating far beyond the time they needed to be closed. The 1970 "Clean Air Act" exempted these older power plants under the assumption that they would soon be retired (Thorner 2011). However, 
the utility companies continued to operate these power plants without retiring them or installing emission controls.

With the new US-EPA standards requiring that operators of aging coal-fired power plants either install costly new retrofits or shut down the plants, most Illinois utility companies are reviewing these new rules to decide the fate of their plants before 2018. The new standard for sulfur dioxide emission in Illinois is 75 ppb measured over one hour (Pekin Times 2011). Most sulfur dioxide emissions in the state are from coal-fired electric power plants and ethanol production facilities. The area around the City of Pekin, the county seat of Tazewell County in Illinois has the highest level of sulfur dioxide air pollution in the state (235 ppb over one hour), according to US-EPA, a level that now exceeds tightened Federal standards (Pekin Times 2011).

It was estimated that compliance with the new clean air standards will bring over 122,000 capital investment jobs in Illinois. In addition, Illinois will benefit from approximately 1,500 permanent jobs in operating and maintaining the new air pollution control equipment (Learner and Rowe 2011). On the other hand, any delay to implement the new US-EPA's transport rule will mean about $\$ 450$ million in lost revenue to Illinois every year. These losses are attributed to reduced productivity from air pollution caused to Illinois from other states.

In Figure 2 we report the profile of electric power industry emissions estimates in Illinois for the period of 1990-2009. This diagram is produced using the data reported by the U.S. Energy Information Agency (US-EIA 2011). According to this figure, carbon dioxide emission from electric power plants increased in the past decade while sulfur dioxide and nitrogen oxide emissions decreased. 




Figure 2. Profile of electric power industry emissions estimates, 1990-2009, Illinois (Data from US-EIA 2011)

The new state and government rulings in regard to pollution reduction has brought about new activities towards using clean coal technology for electric power generation in Illinois which are discussed in the next section.

\subsection{Illinois electric power plant projects using clean coal technology}

The clean coal technology (CCT) program which began in 1986 was the most ambitious government-industry initiative ever engaged to develop environmental solutions for U.S abundant coal resources. The U.S Department of Energy (DOE) generally defines clean coal technology (CCT) as a state-of-the-art technology which when implemented improves the environmental performance and efficiency of coal-fired power plants, relative to current coalfired electric power plants. Clean coal technology is commonly referred to all the technologies being developed to reduce environmental impact of energy generation relative to older methods of burning coal (Buchan \& Cao 2004). However, when a technology is proven, it is no longer classified as CCT; but instead, it is considered as best available control technology or best available retrofit technology that can be used commercially. Several clean coal technology 
options are currently available, but the economic viability of some of them remains questionable due to high energy taxes. There are many clean coal technology projects currently being undertaken in Illinois to make the state a leader in clean and efficient use of coal in the foreseeable future. Four important Illinois clean coal technology projects, which are Prairie State Energy Campus (PSEC) project, FutureGen 2.0 project, coal-to-gas IGCC power plants projects, and Taylorville Energy Center, are discussed briefly here:

2.3.1. PSEC project: A major clean coal technology project in Illinois is the Prairie State Energy Campus (PSEC) and its adjacent Lively Grove New Coal Mine in Washington County (IDCEO 2010). The Prairie State Energy Campus (PSEC) belongs to Peabody Energy (the nation's biggest coal company) and eight not-for-profit public power companies. The projected total cost for the development and construction of the twin- $810 \mathrm{~mW}$ electric unit power station is nearly \$4 billion (IDCEO 2009). The project will generate sufficient electricity to serve approximately 2.5 million families. This new power station will use the technology of pulverized coal producing supercritical steam (see Section 2.3.5.1.) and up-to-date equipment for postcombustion flue-gas clean-up.

The plant will use 6.3 million tons of coal per year from the adjacent newly constructed Lively Grove underground mine. The estimated carbon emissions will be $15 \%$ lower than the typical U.S. coal-fired power plant. The partial startup date for the 1,600 $\mathrm{mW}$ power plant was December 2011 (Coal age 2011). The unit 2 of the twin power plant was scheduled to go on line not later than the summer of 2012. The adjacent Lively Grove New Coal Mine current coal reserve is 200 million tons and is projected to last for nearly 30 years (Coal Age 2011). The plant is estimated to add about $\$ 785$ million annually to Illinois economy (Coal age 2011). Furthermore, nearly 450 full-time employments are estimated to be created by the project, which out of this number about three-fourths would be at the coal mine.

2.3.2. FutureGen 2.0 project: The FutureGen 2.0 project is a private partnership between the U.S. DOE and the FutureGen Alliance, a consortium of companies including Babcock \& Wilcox, Air Liquide Process \& Construction and Ameren Energy Resources. The project is a revised version of the FutureGen Project which was cancelled by the DOE in January 2008, due to 
escalating cost. However, in September 2010, DOE reached an agreement with the Alliance for the construction of FutureGen 2.0, a full-scale advanced oxy-combustion technology on an existing Ameren 200-mW coal-fired power plant in Meredosia, Illinois (McDonald et al. 2011; U.S. DOE 2009). The FutureGen 2.0 Project consists of retrofitting the shuttered coal-fired power plant to demonstrate the advanced oxy-combustion technology, and transportation of carbon dioxide for underground storage (Lee 2011). Principles behind oxy-combustion technology are presented in Section 2.3.5.2. The project will demonstrate a large scale feasibility of the technology in meeting emission standards, confirm the cost basis for retrofitting and repowering existing coal-fired units, provide the information and experience that will reduce the cost for larger plants in future and establish operating and maintenance experience for future commercial plants. Furthermore, the project will confirm the technical and economic feasibility of efficiently producing low-cost electricity from coal, while nearly eliminating emissions. The cost of the new project is estimated to be $\$ 1.3$ billion and is supposed to generate $200 \mathrm{~mW}$ of gross electricity (140 $\mathrm{mW}$ of net electricity), capture 1.3 million tons per year of $\mathrm{CO}_{2}$, and have near-zero emission of $\mathrm{NO} x, \mathrm{SO} x$, mercury, particulates and other hazardous air pollutants (McDonald et al. 2011). A 32-mile pipeline will be constructed to pump the plant's carbon dioxide emissions into a 4,500 feet deep underground geologic formation with estimated capacity of over 1.3 million tons per year, located at Morgan County in Illinois.

2.3.3. IGCC power plants: In July 2011, the Governor of Illinois signed a bill that could begin the construction of two coal-to-gas IGCC power plants to produce synthesis gas (syngas) in 2012 (Wernau \& Karp 2011; Wells 2011). The principles behind IGCC technology is described in Section 2.3.5.3.

One of the plants will be constructed by Chicago-based Power Holdings, LLC near Waltonville in the Jefferson County of Southern Illinois and would cost approximately \$2.3 billion. The plant will use nearly four million tons of Southern Illinois coal per year and create around 1,000 construction jobs, 300 permanent mining jobs and 250 permanent plant positions while providing gas to 500,000 homes (Wells 2011).

The other plant will be constructed by New York - based Leucadia National Corp at the Southeast Side of Chicago at the cost of nearly $\$ 3$ billion (Wernau \& Karp 2011). This modern coal gasification plant will produce synthesis gas (syngas) and will be developed on a brownfield 
site within the Chicago-Calumet industrial corridor. The plant will use about 1 million tons of Illinois coal per year, together with petroleum coke to produce synthetic gas. The proposed Illinois coal-fueled facility will use General Electric quench gasifier to produce substitute natural gas and electricity from the waste stream. About $85 \%$ of the carbon dioxide from the plant will be captured and sequestered.

These projects are expected to create thousands of jobs, spur economic growth in the communities, replace the 1950s coal-fired power plants and demonstrate clean use of Illinois coal. Additionally, a new pricing formula with ten years guarantee would be introduced by law to protect consumers from price volatility.

2.3.4. Taylorville Energy Center project: A proposed project waiting for approval from the Illinois General Assembly is the construction of the Taylorville Energy Center at Christian County in Southern Illinois. The project is a joint venture between Tenaska Inc., an energy company based in Omaha, Nebraska, and MDL Holding Co. of Louisville, Kentucky. The project would use Hybrid Integrated Gasification Combined Cycle (HIGCC) technology to convert Illinois coal into pipeline-quality synthetic gas to generate wholesale electricity (Flores et al. 2010). However, the full scale $602 \mathrm{~mW}$ Hybrid IGCC electric power plant at a projected cost of $\$ 3.5$ billion was opposed by the Illinois Senate, despite being earlier approved by the Illinois House of Representatives. The Illinois Commerce Commission (ICC) has also expressed concerns about the exorbitant cost relative to the cost of other energy generation technologies and "uncertain future benefits" of the project (Flores et al. 2010). For example the cost per $\mathrm{mWh}$ electricity by traditional coal-fired power plants is $\$ 141.08$ - $\$ 153.03$, for nuclear power plants is \$101.45 - \$128.03, while for Taylorville Hybrid IGCC is \$212.73.

The proposed Taylorville HIGCC power plant is expected to capture more than $50 \%$ of carbon dioxide (about 1.9 million tons per year) that will be transported via pipelines for storage. The project is expected to generate enough electricity to power about 600,000 homes in the Taylorville area and create more jobs. The Illinois Senate Bill (SB 1987), created the Clean Coal Portfolio Standard, requiring utility companies to purchase $5 \%$ of the electricity from coal-fired plants that capture at least half of the carbon dioxide. But the law limited the rate impact from the Taylorville project to $2 \%$ for residential customers. By 2017, all new coal-fired power plants built in Illinois will be required by law to store at least $90 \%$ of total carbon dioxide emissions. 
Opponents of the Taylorville project claim that the technology is too expensive and not proven. Besides, there are claims that capturing $90 \%$ of the emissions from this HIGCC power plant could increase the total cost of electricity because the processes involved in capturing the emissions is energy intensive.

In late November 2011, the Illinois Senate finally passed a bill (SB 678), granting permission for the construction of the $\$ 3.6$ billion Taylorville coal-to-gas electric generating plant. The bill would make the Taylorville plant eligible for a tax credit estimated at $\$ 8.7$ billion over 30 years period and includes provisions that require the major state utility companies to purchase electricity from the plant for 20-30 years (Yeagle 2011).

In Table 3, we compare the compiled characteristics of the three new energy generation projects (power plants) reported by various sources as referenced.

Table 3. Comparison of new energy generation projects in Illinois.

\begin{tabular}{|c|c|c|c|}
\hline Issue & Prairie State Energy & FutureGen 2.0 & Taylorville \\
\hline Type of power plant & Supercritical $^{(1)}$ & Oxy-combustion $^{(8)}$ & $\mathrm{HIGCC}^{(4)}$ \\
\hline Gross plant capacity & $1600 \mathrm{~mW}^{(1)}$ & $200 \mathrm{~mW}^{(2)}$ & $716 \mathrm{~mW}^{(4)}$ \\
\hline Product & Electricity $^{(1)}$ & Electricity $^{(2)}$ & Electricity $+\mathrm{SNG}^{(4)}$ \\
\hline Projected cost $\left(\$ 10^{y}\right)$ & $4-5^{(1,7)}$ & $\sim 1.3^{(3)}$ & $\sim 3.6^{(4)}$ \\
\hline Cost of electricity per mWh & $\begin{array}{l}\$ 58-63.45 \text { for plants first } \\
\text { operation }{ }^{(7)}\end{array}$ & NA & $\$ 212.73^{(4)}$ \\
\hline Annual coal consumption & $6.3 \times 10^{6}$ tons $^{(1)}$ & NA & $(1.5-2.4) \times 10^{6}$ tons \\
\hline $\mathrm{CO}_{2}$ emission & $\begin{array}{l}15 \% \text { less than typical US } \\
\text { coal-fired power plants }^{(1)}\end{array}$ & $>90 \%$ captured $^{(2)}$ & $\begin{array}{l}\text { Capture: }>50 \% \text { captured } \\
\text { facility-wide and }>90 \% \\
\text { captured from gasification }^{(6)} \\
\text { island }^{(6)}\end{array}$ \\
\hline $\begin{array}{l}\text { Estimated annual economic } \\
\text { Impact }\end{array}$ & $\$ 785 \times 10^{6(1)}$ & NA & $>\$ 350 \times 10^{6(9)}$ \\
\hline Estimated no. of Jobs creation & $450^{(1)}$ & $\begin{array}{l}900 \text { construction or } \\
\text { direct jobs and } 1000 \\
\text { indirect jobs }{ }^{(5)}\end{array}$ & $\begin{array}{l}16,000 \text { direct / indirect } \\
\text { construction -related jobs }{ }^{(6)}\end{array}$ \\
\hline Projected customers & $2.5 \times 10^{6}$ families $^{(1)}$ & NA & $6 \times 10^{5}$ homes $^{(4)}$ \\
\hline Proposed completion date & $2013^{(I)}$ & April $2016^{(8)}$ & $2017^{(9)}$ \\
\hline
\end{tabular}

(1) Coal Age 2011; (2) McDonald et al. 2011; (3) US-DOE 2009; (4) Flores et al. 2010; (5) U-DOE 2010;

(6) Lundy and Salmi 2012; (7) Lydersen 2012; (8) McDonald and Sturm 2012; (9) Jana Martin of Tenaska, Inc.

(Private communication); NA=not available.

In Table 4 we compare the cost per megawatt-hour $(\mathrm{mWh})$ of electricity generation of the new energy generation projects (power plants) (as also reported in Table 3) with traditional coal-fired power plants, a nuclear power plants, IGCC power plants and wind energy power plants. Obviously the reported data for the Prairie State Energy Campus does not seem to be reasonably 
accurate in general. This low cost per megawatt-hour electricity is the Average Costs to Participants of the project. This cost is far less than the wholesale electricity price because the 68 member participants of the project are locked in to a contract for several years.

Table 4 - Comparison of the Cost per mWh electricity generation by various power plants

\begin{tabular}{|c|c|}
\hline Kind of Power Plant & Cost per mWh electricity \\
\hline Prairie State Energy Campus & $\begin{array}{l}\$ 58.18-68.01 \\
\text { (Average Costs to Participants) }\end{array}$ \\
\hline The FutureGen 2.0 project & NA \\
\hline Taylorville HIGCC $^{(1)}$ & $\$ 212.73$ \\
\hline Traditional coal-fired $^{(1)}$ & $\$ 141.08-153.03$ \\
\hline Nuclear ${ }^{(1)}$ & $\$ 101.45-128.03$ \\
\hline 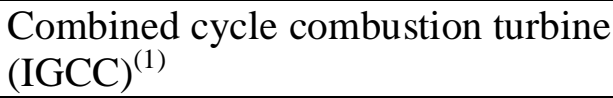 & $\$ 154.05-160.78$ \\
\hline Wind $^{(1)}$ & $\$ 88.80-121.97$ \\
\hline
\end{tabular}

(1). Flores et al. 2010

2.3.5. Science and engineering basis of Illinois electric power plant projects using clean coal technology: In this section we briefly report on the basic technologies of the new Illinois electric power plant projects.

\subsubsection{Supercritical and ultra-supercritical steam cycle}

2.3.5.1.A. Supercritical steam cycle: The technology of pulverized coal producing supercritical steam uses higher boiler design pressures to raise the water boiling temperature and the average temperature of the heat input. For bituminous coal (such as Illinois coal), about $70-75 \%$ of the fine coal particles size is below $75 \mu \mathrm{m}$, while less than $2 \%$ of the particles are over $300 \mu \mathrm{m}$ (IEA 2011). This finely powdered pulverized coal is blown with a portion of the combustion air into the furnace through a series of burner nozzles. The combustion process is enhanced by the use of secondary and tertiary air injection into the combustion chamber. Depending on the rank of coal, combustion would occur at temperatures ranging from $1300-1700^{\circ} \mathrm{C}$, with typical residence time of particles ranging from 2-5 seconds (CIAB 2010). 
There are two types of boiler designs used in supercritical steam generation which include the traditional two-pass layout boiler and the tower type boiler. The two-pass layout boiler type consists of a furnace chamber, topped by heat transfer tubings, which recovers the flue-gas heat content and, as a result, it further reduces the flue-gas exit temperature. In the tower boiler nearly all the heat transfer sections is mounted vertically above each other over the combustion chamber (CIAB 2010). This system allows the increase of water pressure and temperature above its critical point values ( $221 \mathrm{bar}$ and $374{ }^{\circ} \mathrm{C}$, respectively) which is known as the supercritical condition (CIAB 2010; Park et al. 1987; Mansoori 1989).

This results in a corresponding increase of the average temperature of the steam entering the turbines. Higher temperature steam contributes to an increase of the thermal (Rankin) cycle efficiency of the power plant by almost $2 \%$, which results in less fuel usage and less greenhouse gas production (IEA 2011). Boilers operating at supercritical conditions do not require hot reservoirs or steam drums because supercritical steam is highly dry and there is no need to separate water and steam (CIAB 2010). The advantages of supercritical steam coal-fired electric power plants include higher net efficiency and lower greenhouse gas emissions compared to those of conventional sub-critical steam coal-fired electric power plants (see Table 5). On the negative side, supercritical-steam coal-fired electric power plants are often perceived as unproven and costly technology unsuitable for local coal, especially coal with high ash content (Burnard and Bhattacharya 2011). Figure 3 shows the schematic diagram of the supercriticalsteam coal-fired electric power plant technology. 


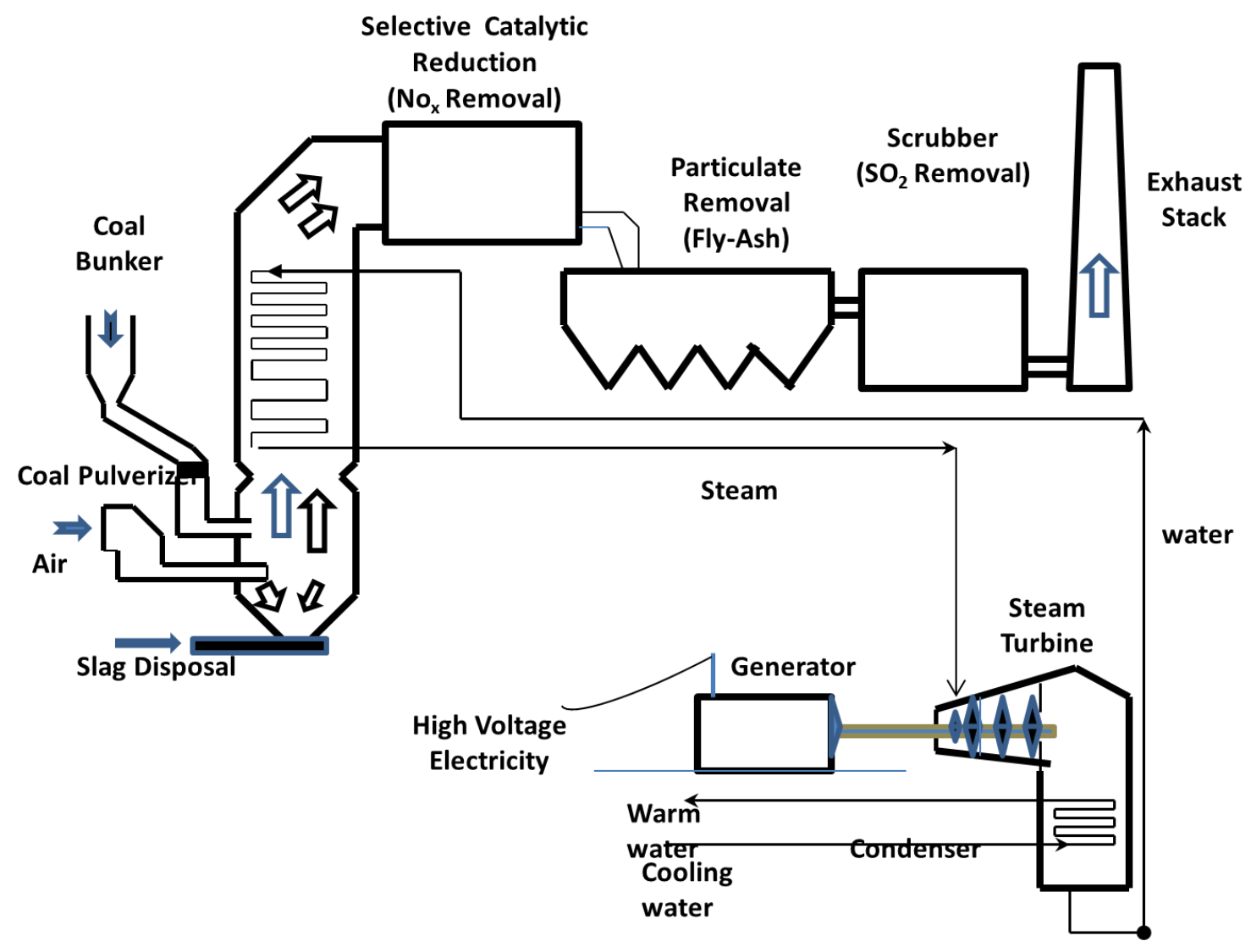

Figure 3. Typical supercritical and ultra-supercritical coal-fired plant (Environmental Engineering Solutions 2008)

2.3.5.1.B. Ultra-supercritical steam cycle: Boilers operating at supercritical pressure above 240 bars and supercritical temperature above $593^{\circ} \mathrm{C}$ are classified as ultra-supercritical boilers (CIAB 2010). Increasing the temperature and pressure of steam to ultra-supercritical conditions will further increase the Rankin cycle efficiency of the power plant that use steam as the working fluid with improved environmental performance. The ultra-supercritical steam cycle is a cleancoal technology that can be considered by Illinois as an alternative solution to reduce power plant emissions. Figure 3 shows the schematic diagram of the ultra-supercritical-steam coal-fired electric power plant technology.

The ultra-supercritical-steam coal-fired electric power plant technology is currently the most efficient technology for electricity production using pulverized coal, with efficiencies hovering around 42\% (IEA 2008; Purget et al., 2011). Supercritical- and specially ultrasupercritical-steam is highly reactive with inorganic materials including many metals (Touba and 
Mansoori, 1998; Touba et al. 1998). The world's first ultra-supercritical electric power plant (Philo Unit 6) in Ohio, built by American Electric Power (AEP) could not operate at ultrasupercritical conditions constantly, due to failure of the material of construction when subjected to prolonged high pressures and temperatures and especially in contact with ultra-supercritical steam (Sigmon 2008). Consequently, the power plant was finally operated at supercritical conditions until it was decommissioned. But with recent metallurgical advancements in the design of high pressures and temperature materials with higher creep-strength-enhanced ferritic steels, advanced austenitic alloys, and nickel-based alloys, ultra-supercritical power plant has become practical (Purget et al. 2010).

Lately, almost two dozen ultra-supercritical coal-fired power plants have been commissioned globally. Among those is the Waigaoqiao III ultrasupercritical power plant in Shanghai, China, which reportedly has been saving some 900,000 tons of raw coal and reducing carbon dioxide output by 1.9 million tons since start-up in 2008 (Patel 2010a). Also, among the ultrasupercritical power plants currently under construction is the state-of-the-art $€ 1.4$ billion, $800 \mathrm{~mW}$ Lünen plant located at the outskirt of Lünen in Germany (Probasco \& Ruhlman, 2011). The net efficiency of this plant is around $45.6 \%$ and the boiler outlet steam conditions are 280 bars pressure and temperature range of 600 to $610^{\circ} \mathrm{C}$. Late in the year 2012 was defined as the expected date of service of this plant using low-sulfur bituminous coal. In the U.S., America Electric Power is building a $600-\mathrm{mW}$ ultra-supercritical plant in Arkansas. The boiler outlet steam conditions for this plant are 250 bars and 602 to $610^{\circ} \mathrm{C}$. This $\$ 1.5$ billion project scheduled for completion in late 2012 is the only ultra-supercritical power plant in this country (Purget et al., 2011). The latest ultra-supercritical steam generators can operate at supercritical pressures above 241 bars and at advanced steam temperatures around $593^{\circ} \mathrm{C}$. These operating pressure and temperature of ultra-supercritical steam cycle allow less consumption of coal, fewer emissions and more efficient operation of the turbine cycle. Furthermore, the new construction materials can sustain high temperatures for extended periods of time. Besides improved environmental performance, ultra-supercritical plants are equipped with state-of-the-art emission control technologies, such as dry flue-gas desulfurization system (Hamad 2006) for $\mathrm{SO}_{2}$ reduction and baghouse technology for particulate removal and selective catalytic reduction system for NOx reduction. Currently, the U.S. DOE, in collaboration with Ohio Coal Development Office (OCDO) and other institutions, is researching advanced materials for ultra- 
supercritical coal-fired boilers that can operate at a temperature of $760^{\circ} \mathrm{C}$ and an unspecified pressure (Purget et al., 2011). Also ultra-supercritical steam cycle capable of operating at steam temperatures of $700^{\circ} \mathrm{C}(\mathrm{AD} 700)$ and a pressure of 300 bars are in the research and development stage. The advantages of ultra-supercritical steam coal-fired electric power plants include lower fuel consumption, higher net efficiency and lower greenhouse gas emissions relative to those of supercritical and conventional subcritical steam coal-fired electric power plants (see Table 5). On the negative side, like supercritical power plants, ultra-supercritical steam coal-fired electric power plants are often perceived as unproven and costly technologies that are unsuitable for local coal, especially coal with high ash content (Burnard and Bhattacharya 2011).

Table 5 shows the performance of pulverized fuel power plants using hard coal (anthracite). The net specific $\mathrm{CO}_{2}$ emission in tons per megawatt hour-net (ton/mWh-net) is defined as the amount of carbon produced by a facility per net amount of energy produced by the facility. The net (\%) efficiency is the net electric energy output as a percentage of the fuel energy input of a thermal power plant.

Table 5. Summary of performance of pulverized coal power plants using anthracite / hard coal (Data from IEA 2008)

\begin{tabular}{|l|l|l|l|l|}
\hline Steam cycle & Subcritical & Supercritical & \multicolumn{2}{|c|}{ Ultra-Supercritical } \\
\cline { 4 - 5 } & & & $($ Best available $)$ & $(\mathrm{AD} 700)^{(\mathrm{a})}$ \\
\hline Steam conditions & $180 \mathrm{bar}\left(540^{\circ} \mathrm{C}\right)$ & $250 \mathrm{bar}\left(560^{\circ} \mathrm{C}\right)$ & $300 \mathrm{bar}\left(620^{\circ} \mathrm{C}\right)$ & $350 \mathrm{bar}\left(700^{\circ} \mathrm{C}\right)$ \\
\hline Net output $[\mathrm{mW}]$ & 458 & 458 & 456 & 457 \\
\hline Net efficiency [\%] & 40.2 & 42.0 & 43.4 & 45.6 \\
\hline $\mathbf{C O}_{2}$ emission [ton/mWh-net] & 0.83 & 0.80 & 0.77 & 0.73 \\
\hline
\end{tabular}

(a) $\mathrm{AD} 700=$ Advanced $\left(700^{\circ}\right)$ PF Power Plant-A joint European project: Clean Coal Technology. Industry-focused technology program initiated in 1990 to develop advanced materials which could allow increasing the main and reheat steam temperatures in pulverized fuel (PF) boilers up to $700{ }^{\circ} \mathrm{C}$ or higher.

Because of the negative perceptions about supercritical and ultra-supercritical coal-fired electric power technologies as mentioned earlier in this section, neither of these technologies dominates in the State of Illinois. Although supercritical and ultra-supercritical coal-fired electric power technologies have demonstrated to be commercially viable and competitive, the utility companies prefer using the conventional subcritical technology because they are more familiar with (Burnard and Bhattacharya 2011). 
2.3.5.2. Oxy-combustion technology: Figure 4 shows the oxy-combustion technology used for the FutureGen 2.0 project in Illinois (WNA 2011). The oxy-combustion plant consists of a conventional coal-fired power plant, air separator and gas clean-up equipment.

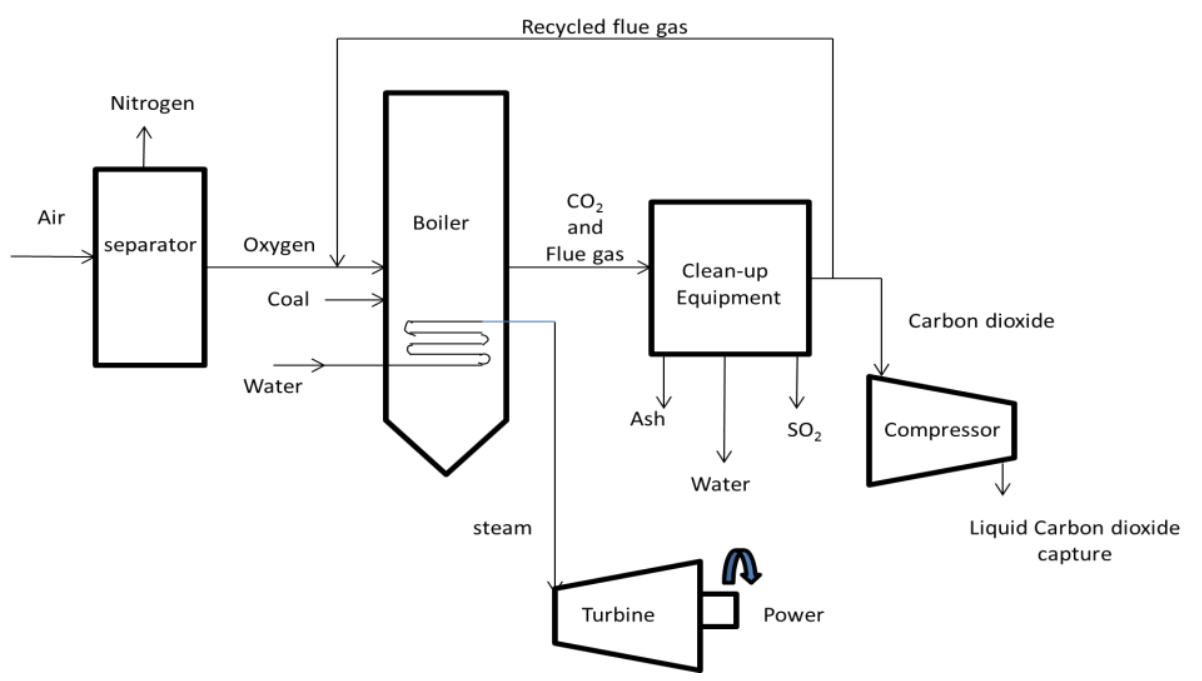

Figure 4. Schematic diagram of the oxy-combustion process (McDonald et al. 2011)

The oxy-combustion separates oxygen from air and combines it with coal for the combustion to proceed in a mixture of carbon dioxide and oxygen medium (Phillips and Maxson 2011). The resulting flue-gas then has about 70 to $90 \%$ (dry basis) carbon dioxide. The high purity of carbon dioxide facilitates its easy collection, transportation and storage. Oxy-combustion plants are constructed to be highly reliable because of their proven commercial components. They are also attractive to the utility industry because their operation is very similar to pulverized coalfired power plants. In addition, their operating scheme is developed to maximize revenue during times of dramatic price fluctuations. They also have design flexibility for partial capturing of carbon dioxide whenever $\mathrm{CO}_{2}$ regulations start below $90 \%$, or full capturing when it is above 90\%. Also, the primary component for the removal of NOx and nitrogen in flue-gas is eliminated using air separating unit. The variable operation and maintenance (O\&M) cost for an oxy-combustion supercritical technology with carbon capture is $\$ 6.15 / \mathrm{mWh}$. On the other hand, the variable O\&M cost for an oxy-combustion ultra-supercritical technology with carbon capture is $\$ 5.69 / \mathrm{mWh}$. The major advantage of the latter technology is that it facilitates carbon dioxide capturing by producing high concentration of carbon dioxide in the flue gas, and by providing 
additional flue gas purification, dehumidification and pressurization (Global CCS Institute. 2009).

2.3.5.3. Integrated Gasification Combined Cycle (IGCC): Figure 5 shows the block diagram of the IGCC plant. The basic principle of the IGCC technology is to convert coal into synthesis gases (syngas) at high temperature and pressure, clean-up the gas, then combust it in a two-stage process to produce steam for electricity generation. The pollutants from the process are converted into reusable products to reduce emissions. It is estimated that the levelized-cost of energy using the IGCC and carbon capture and sequestration technology will be between \$126 and $\$ 152$ per megawatt hour (Wernau 2011). Additionally, the plant can reduce emission levels to $1.0 \%$ of that of traditional coal-fired power plants. By creating the Illinois Clean Coal Portfolio Standard Law (SB 1987), Illinois law makers hope that the use of IGCC power plants in the state would curtail greenhouse gas emissions, while making the high sulfur content coal in Illinois attractive for the state's electric power plants. Consequently, in July 2011, the Governor of Illinois signed into law two coal-to-gas bills to pave the way for the construction of two IGCC plants in Illinois (Wernau \& Kalp 2011; Well 2011).

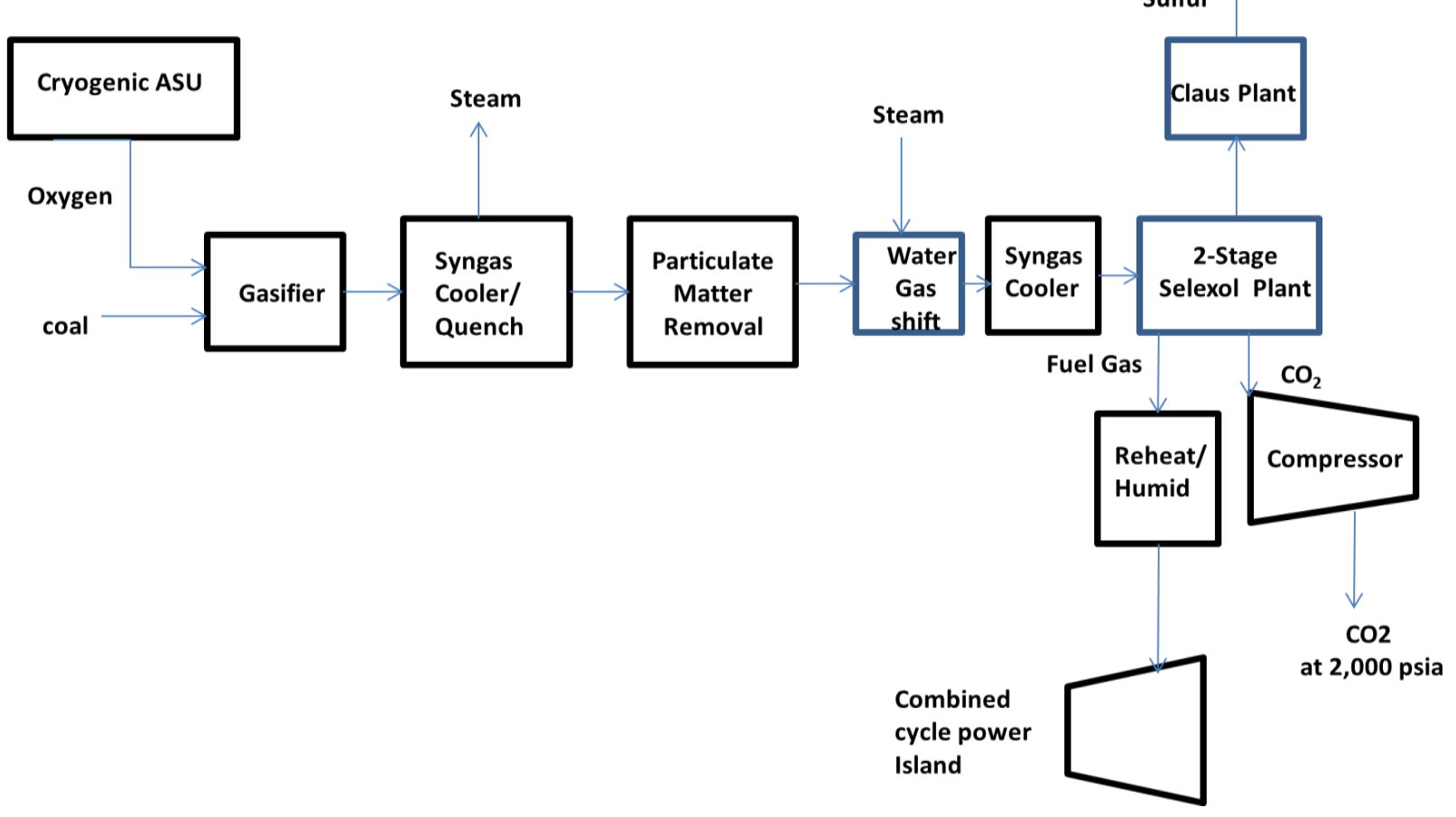


Figure 5. IGCC (Integrated Gasification Combined Cycle) with carbon capture and sequestration plant configuration [US-EIA 2010]

The first step in gasification process is pyrolysis, which occurs at a temperature of over $400^{\circ} \mathrm{C}$ and in the absence of oxygen/air. In this step, the hydrogen-rich volatile organic gases are driven out of the coal in the absence of oxygen to reduce it to carbon-rich char. In the second step, the char is gasified, using appropriate amounts of pure oxygen (as produced in a cryogenic air distillation process (see Chiu and Newton 1980) and steam to produce $\mathrm{CO}$ and $\mathrm{H}_{2}$ gases at a temperature of over $700^{\circ} \mathrm{C}$, leaving behind ash as by-product. The overall reactions for this step are (WNA 2011).

$$
2 \mathrm{C}(\mathrm{s})+\mathrm{O}_{2}(\mathrm{~g}) \rightarrow 2 \mathrm{CO}(\mathrm{g})
$$

$\mathrm{C}(\mathrm{s})+\mathrm{H}_{2} \mathrm{O}(\mathrm{g}) \rightarrow \mathrm{CO}(\mathrm{g})+\mathrm{H}_{2}(\mathrm{~g})$

The resulting synthesis gas (syngas) which is essentially hydrogen and carbon monoxide is cleaned up before combustion in the gas turbine. The hot gases exiting the gas turbine are used to produce steam to generate more electricity. A typical IGCC power plant based on this system of reactions has a thermal efficiency of about $45 \%$. Consequently, current research work on the IGCC technology is focused on adding a water-gas shift reactor to oxidize $\mathrm{CO}$ with water, such that the exiting gas stream will be essentially hydrogen and carbon dioxide, with a small quantity of nitrogen and other impurities such as hydrogen sulfide and mercury (WNA 2011).

Water-gas shift reaction: $\quad \mathrm{CO}(\mathrm{g})+\mathrm{H}_{2} \mathrm{O}(\mathrm{g}) \rightarrow \mathrm{CO}_{2}(\mathrm{~g})+\mathrm{H}_{2}(\mathrm{~g})$

After carbon dioxide and other impurities are removed from the reaction product, then hydrogen becomes the only fuel for energy generation. The heating value of the hydrogen produced is about $28,900 \mathrm{kcal} / \mathrm{kg}$ (i.e. five times higher than coal in terms of energy density). By using hydrogen in a gas turbine for mechanical energy generation, the overall system efficiency in the long-term is expected to be about $60 \%$ (WNA 2011). 
Approximately $85 \%$ of the carbon dioxide is captured for sequestration, while the hydrogen sulfide is reduced to elemental sulfur using the Claus process. However, the energy requirement for the air separation plant used to produce oxygen for partial combustion of coal leading to the water-gas shift reaction consumes about $20 \%$ of the gross power generated by the plant. For this reason, there is currently no commercial-scale IGCC power plant using hydrogen fuel. One way to reduce this power loss, with corresponding reduction in capital cost of the IGCC plant is to replace the cryogenic air distillation unit with ion-transport membrane oxygen technology (WNA 2011). This technology uses a ceramic membrane - a complex metal oxide which, under pressure and temperature, ionizes and separates oxygen molecules from air (Dyer, et al. 2000). The technology does not require external source of electrical energy. Therefore, compared to traditional cryogenic air separation units, ion transport membrane technology could reduce the IGCC power plant internal power requirement by as much as $30 \%$, while reducing the capital cost by almost 30\% when installed with either oxy-combustion or IGCC power plants. However, these membranes need frequent replacements which will increase the operating cost of the IGCC power plant.

\subsubsection{Hybrid Integrated Gasification Combined Cycle (HIGCC): The HIGCC technology} as mentioned in section 2.3.4 is an IGCC technology with a methanation unit added to the process for converting the syngas into pipeline-quality substitute-natural-gas (SNG) or methane. Part of the SNG produced in this process can be used for electric power generation, while the balance can be used for household use. Hence, this technology is called 'hybrid', since it can supply both chemical and electrical energy simultaneously. Figure 6 shows the block diagram of the HIGCC technology process. The syngas produced from the gasification process is cleaned in the particulate scrubber, prior to conversion into SNG in the methanation unit as shown by the equation below.

$\mathrm{CO}+3 \mathrm{H}_{2} \rightarrow \mathrm{CH}_{4}+\mathrm{H}_{2} \mathrm{O}$

The higher energy density of the SNG, relative to that of syngas improves the efficiency of the power generation (Flores et al. 2010). 


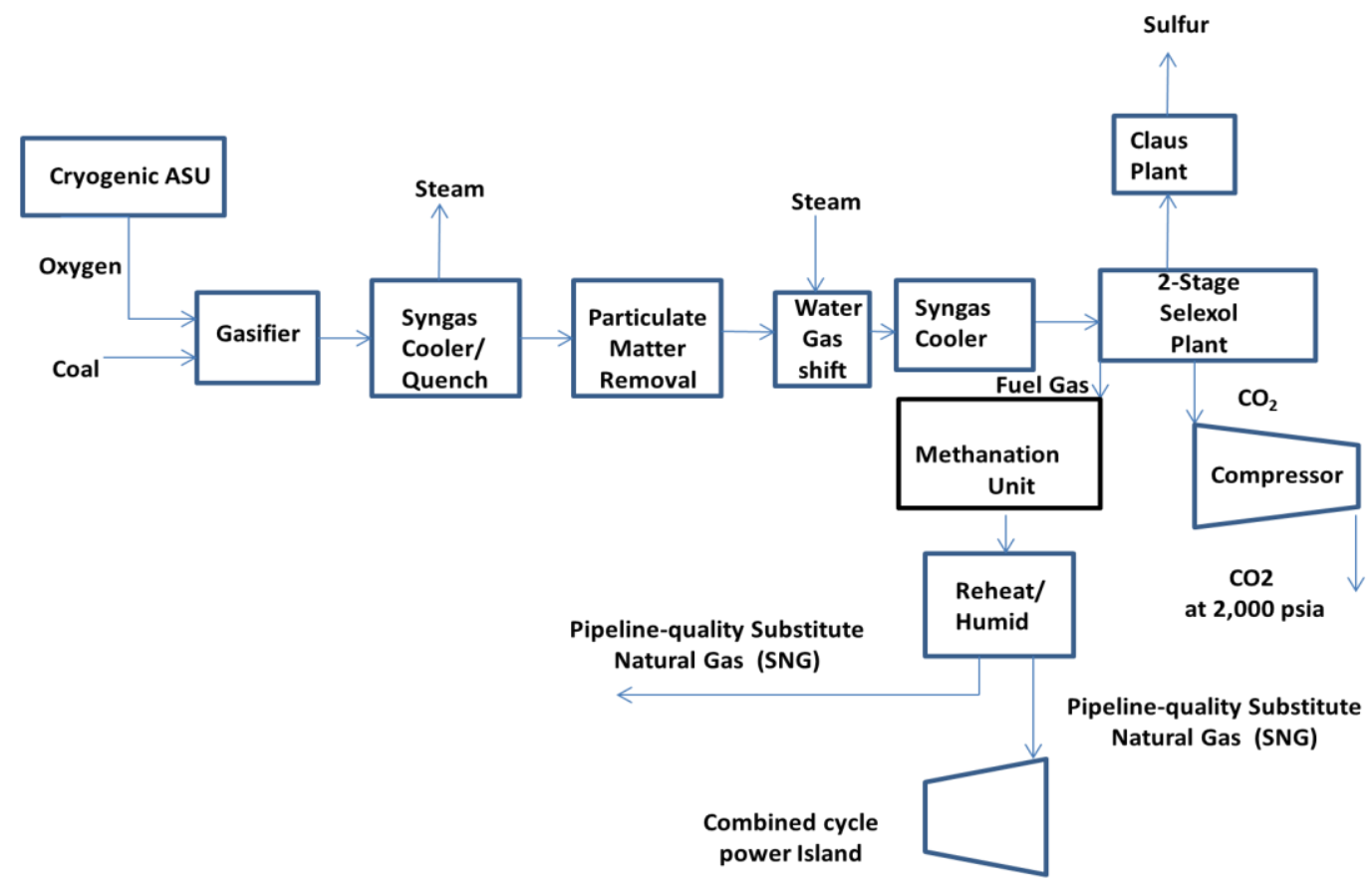

Figure 6. HIGCC (Hybrid Integrated Gasification Combined Cycle) plant configuration [Flores et al.2010].

\subsection{Underground coal gasification (UCG) potential in Illinois}

The unminable coal seams in Illinois have long been recognized as good targets for underground coal gasification (UCG) as shown in Figure 7. The early efforts of pre-commercial scale application of UCG technology foundered on several requirements. These requirements included the proximity of the UCG mine to population areas in need of the products of gasification and the availability of dedicated surface facilities that could process and use the large volume of gas and energy produced from the UCG. 


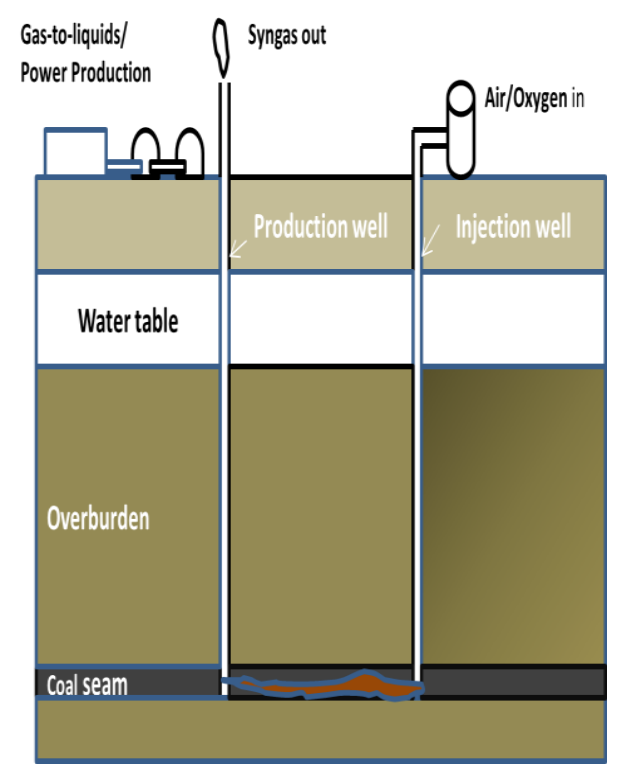

Figure 7. Underground gasification of coal (Patel 2010b)

In 1981 DOE funded Hammesfahr, Winter \& Associates, Inc. to determine the existence of adequate surface infrastructure in any US states with UCG amenable coal reserves. These infrastructures would provide an industrial application, as well as revenues for the synthesis gases produced from the pre-commercialization project, using a multi-well field test. Illinois was selected among five states for the project because of its important coal reserves and its proximity to major markets. New Mexico, Washington state, and Wyoming were included on the list based on their broad data base on western coals, while Texas was selected because of its local interest in UCG. Since the objective of the project was to reduce the construction of new surface facilities, the selection criteria was focused on three major fuel consumers: The utility industry, the refinery industry, and natural gas processors. However, an exception was granted to states with facilities which could produce transportation grade methanol for local use, using UCG products. The estimated rate of production for the pre-commercialization test was $1.21 \times 0^{12} \mathrm{Cal}$ per day, an equivalent of the energy required for 20 megawatts of power production (Hammesfahr and Winter 1983). Table 6 shows the number of potential users of the UGC products by State. According to Table 6 within the 50 miles radius, Illinois has 12, the highest number of potential users. 
Table 6. Number of potential users of UGC products by State in 50-mile radius around the coal resource (Hammesfahr and Winter 1983)

\begin{tabular}{|l|c|}
\hline States & No. of users \\
\hline Illinois & 12 \\
\hline New Mexico & 7 \\
\hline Texas & 3 \\
\hline Washington & 11 \\
\hline Wyoming & 9 \\
\hline
\end{tabular}

In 1982, Williams Brothers Engineering Company conducted a study on UCG amenable bituminous coal resources in US states. Illinois, Kentucky, and Ohio were evaluated as having the required potential test sites for continued research and development in bituminous coal (Martin et al. 1983).

In 1983, Morgantown Energy Technology Center of the U.S. Department of Energy proposed a research and development project for an underground coal gasification technology that could lead to the extraction of energy from the eastern US bituminous coal which included Illinois coal. The overall goal of this project was to establish a data base for the recovery of energy from deep, thin seam, swelling, high sulfur bituminous coals that were less economical to mine. In this proposal, again Illinois, Kentucky, and Ohio were recommended as in Williams Brothers Engineering Company study, as having the best potential sites for the project. The selection criteria for the UCG deep bituminous coal seam site(s) was based on factors, such as coal seam greater than 1.22 meters (4 feet) in thickness, location within a commercially viable quantity of coal, target coal seam of at least 91.44 meters (300 feet) below the water-table, a competent roof and floor structure for the targeted coal seam, and initial coal properties amenable to UCG testing (Martin et al. 1983).

In 1986 a series of laboratory experiments were conducted by Western Research Institute in Laramie, Wyoming to simulate the underground gasification of Herrin bituminous coal from Illinois (Illinois coal \# 6). The test program was conducted under a cooperative agreement with the U.S. Department of Energy. The coal samples were provided by Peabody Coal Company from its River King 3 mine near New Athens in Illinois. The purpose of this test was to address some specific concerns, regarding the use of UCG technology for eastern bituminous coals. These concerns included low permeability, swelling tendency, tar production, coal reactivity and 
geologic setting. The conclusions drawn from these performance tests indicated that the weakly swearing eastern bituminous coal could readily produce 1,680 kCal per standard cubic meter gas in a bore hole link system with good lateral growth. Besides, the swelling tendency of the eastern bituminous coal (with free swelling index of 4 - a value to indicate the coking of coal) does not adversely affect the UCG process and that a sustained gasification is achievable when the coa1 is gasified under ash slagging conditions. Also noted during the performance test was that sidewall reactions and gas flow patterns appeared to control the rate and shape of cavity growth, and therefore lateral cavity growth in thin eastern coal seams may be greater than originally expected (Glasser et al. 1986).

Despite the potential in Illinois for UCG, there has never been any UCG project taking place in the state (Bradshaw \& Dance, 2005). The reason is that most of the UCG projects in the U.S. which began in the early 1960's, were terminated by mid-1980s, due to decline of oil prices around the world. Nevertheless, from 1974 to 1989, there was a surge in research and development of UCG in the United States, with 33 UCG pilot projects located in West Virginia, Wyoming, Alabama, Texas and Washington State. Out of these projects, the most successful one was the Rocky Mountain 1 project, conducted in the 1980s in Carbon County, Wyoming and organized by the U.S. DOE, the Electric Power Research Institute (ERPI), Amoco Production Company, Union Pacific Resources and the Gas Research Institute (GRI) which was based in Illinois.

In 2009 a research report on the potential for underground coal gasification (UCG) cited two coal fields in the Illinois Basin that would meet the important criteria (coal thickness, depth and other characteristics, such as moisture content and heating value for these two coals) for UCG. The coal fields are the Springfield and Seelyville coal beds in southwest of Indiana, located in the Illinois Basin. The report recommended initiating activities on the possibility of locating an UCG pilot project in those coal fields in the future (Peckham 2009). The total capital cost of the future UGC project in Indiana, based on capital expenditures (in \$2009) of an airfired UCG was estimated as $\$ 130.6$ million. This estimate included the cost of drilling, air compression, piping, accessories, gas-cleaning, site facilities, land acquisition, salaries during plant construction, permitting and legal fees, and working capital (SPEA 2011).

Currently, there are no UCG facilities operating in the United States and there are no major U.S. private companies committed to UCG process. However, there is a host of 
institutions in the country involved in various research and development activities in promoting UCG's potential (Friedmann 2009). It is argued that the potential impact of UCG application in the US is to drive down the price of oil, a situation similar to the effect of shale gas utilization on the natural gas price. That is because a large portion of the UCG products may be converted into gasoline and other petroleum products using the Fischer-Tropsch / gas-to-liquid processes.

\subsection{Environmental Concerns about Coal and Clean Coal Technology}

Since coal, petroleum and gas reservoirs are found in the same locations in the Illinois Basin, it appears that the simultaneous exploitation of these resources can be very problematic. As we will discuss in Section 3 on petroleum production and consumption in Illinois, there are many oil and gas wells already drilled in the Illinois basin during the past many years. The large number of oil and gas wells drilled through or near coal mines may penetrate the mines, leading to explosions during mining of coal and possible deaths (Rice et al. 1913). As a result, there are huge amounts of coal left around the oil wells that could not be mined due to explosion hazard. In the past years, the methods for protecting coal mines from gas and oil wells leakages have included open workings and pillars or coal that may be left as pillars. But the use of coal pillars for separation of coal mines from oil and gas leaks results in the loss of coal. These problems would exasperate with a dramatic increase in mining of Illinois coal which is envisioned for application in clean coal technology to produce electricity.

There is a major concern about the health of coal miners and that of the residents of coal mining areas. Underground coal miners frequently suffer from diseases, such as pneumoconiosis (black lung disease) caused by breathing of coal dust. The effects of this disease include shortness of breath, as well as the risk of having emphysema, bronchitis and fibrosis diseases. According to the National Institute for Occupational Safety and Health (NIOSH), from the year 2005 to $2006,9 \%$ of miners with 25 or more years of mining experience tested positive for the black lung disease, as opposed to only $4 \%$ in the late 1990 s.

Apart from coal miners' health problems, the pollutants from coal mining are associated with chronic illnesses among the residents of coal mining communities. In 2008, a study conducted indicated that the residents of coal mining communities have $70 \%$ increased risk of having kidney disease, 64\% increased risk for developing chronic obstructive pulmonary 
diseases (COPD) and 30\% more likely to have high blood pressure (hypertension). Also the same study indicated that human mortality rates are higher in coal mining communities compared to other areas in US (Energy Justice Network 2012). It is envisioned that such problems will be more severe with mining of high sulfur coal.

Furthermore, there are concerns about public safety and the environment, since the public are against coal mining at mountaintops (mountaintop removal mining), a process which entails the removal of up to 305 meters $(1,000$ feet) of soil at the top of mountains, in order to gain access to the underlying coal seams (Jasmine 2009). Such a process has serious repercussions on the ecological balance of the environment because it degrades the natural landscape. An example of such a scene is in the Appalachian Mountains, where an estimated one million acres of forests have been destroyed in coal mining. According to the U.S. Environmental Protection Agency, an estimated 1,931 kilometers of rivers and streams in US have already been buried permanently, as a result of mountaintop removal of soil for coal (Palmer et al. 2010). Also coal mining at mountaintops produces slurries that contain heavy metals and carcinogens which are discharged into open lagoons. The pollutants from these lagoons can contaminate underground drinking waters. In 1972, a flood from a waste pond at Buffalo Creek in Logan County, West Virginia killed 125 people, injured 1,000 others, and left 4,000 people homeless. Also in 2000, a waste pond in Inez, Kentucky spilled over 300 million gallons of pollutants into local waterways (Reece 2006; Palmer et al. 2010). Additionally, mountaintop removal of soil in coal mining threatens the livelihood of many people. For example, there are claims that some families living close to the Appalachian Mountains were threatened by the mining companies who wanted to dislocate them in order to facilitate their mining activities (Jasmine 2009).

There is a concern that the carbon dioxide capture and sequestration (CCS) technology may significantly contribute the onslaught of climate change which is fast approaching. It is estimated that the earliest possible time for commercial-scale deployment of the CCS technology would be after 2030 (Jasmine 2009). Furthermore, other studies have indicated that there are potential problems associated with the integrity of $\mathrm{CO}_{2}$ storage reservoirs, due to chemical reactions from the $\mathrm{CO}_{2}$ injection. For example, the injected $\mathrm{CO}_{2}$ has the tendency to acidify the fluids in the reservoir, which can dissolve minerals such as calcium carbonate to cause formation damage by increasing the permeability of the underground rock, the repair of which would be highly expensive (Paktinat and Mansoori 1993). Enhanced rock permeability can cause the 
escape of $\mathrm{CO}_{2}$-rich fluids from the reservoir through different pathways, which may pollute underground drinking waters. Besides, since $\mathrm{CO}_{2}$ is heavier than air, it could cause affixation in case of any leakage into enclosed living areas of humans and livestock. In 1986, a large quantity of $\mathrm{CO}_{2}$ emissions from a volcanic crater in Lake Nyos in Cameroon, West Africa killed 1,700 people (Kling et. al. 2005). Also there are concerns about transportation of $\mathrm{CO}_{2}$ in pipelines, especially in populated areas, because it has similar environmental risks as a result of accidental leakage (Folger 2009).

The major problems confronting the development of clean coal technologies are mounting costs of projects, marginal improvements in technology efficiencies due to high cost of environmental cleanup of pollutants, and carbon dioxide sequestration difficulties and cost. Also the high capital cost of clean-coal technologies make it difficult for it to compete with other alternative fuels for electricity generation. In addition to high capital cost, clean-coal technologies require improvements in their efficiency and ability to achieve widespread deployment. But this efficiency improvement is often hampered by factors such as high combustion temperatures, which have the tendency to breakdown the combustion turbines, resulting in frequent plant downtime and loss of revenue (SRI Consulting 2012).

\section{Petroleum}

\subsection{Petroleum production in Illinois}

In Southeastern Illinois there are numerous natural underground petroleum reservoirs. Illinois oil production reached its peak around 1941, when several major oil and gas companies were operating in the Illinois Basin (Leetaru et al. 2009). Until 1970, Illinois was one of the major oil-producing states in the United States. Currently, Illinois is a minor oil producer, ranking a distant $14^{\text {th }}$ among states in the United States, with an 2009 production estimate of 9.1 million barrels of crude oil. Illinois' high quality, light sweet southern crude oil (with the API gravity of about 36.8) is attractive to refiners, despite having a lower gasoline yield of $27.50 \mathrm{wt} \%$ or $2 \%$ less gasoline per unit volume than West-Texas-intermediate crude oil (with the API gravity of about 39.6) benchmark crude oil (IOGA 2009). Until now, approximately 16,000 oil wells have been drilled in the Illinois Basin, representing about $3 \%$ of all the U.S wells in oil production 
(Lewis and Bergeron 2010). Out of the 16,000 oil wells, over $90 \%$ are marginal wells, each producing a mere 1-2 barrels a day (Lewis and Bergeron 2010).

In 2009, the United States Energy Information Administration (US-EIA) reported Illinois recoverable proven crude oil reserves as 66 million barrels (US-EIA 2011). Oil exploration activities in the Illinois Basin in the 1970's led to the discovery of a more mature resource base (i.e. subsurface regions with organic matter which has undergone complete thermal transformation) rich in hydrocarbon deposits, with presumably $60 \%$ of the original-oil-in-place (assessed in 2009) still unrecovered (Leetaru et al. 2009). However, the relatively shallow depths of the reservoirs of most of these oil reserves in the Illinois Basin makes the long term prospects of oil production unlikely (IOGA 2011). The current Illinois oil resource will require more advanced technology than what was required during the first one hundred years of oil production in the state. For this reason, the major oil companies abandoned the mature oil fields in the Illinois Basin, while prospecting for oil fields in the US Gulf Coast or Texas and in Alaska which are less expensive to develop. Since then, oil prospecting in the Illinois Basin was mostly undertaken by small local companies (IOGA 2011). However, activities in the Illinois basin have started to change recently because of advanced technology. Since 2011, there has been continuous influx of larger oil companies into Southern Illinois, in the Illinois Basin, buying mineral rights for oil prospecting, a situation which is reminiscent of what happened in the early 1900s regarding coal rights (Tyrpak and Livingston 2012). In April 2012, Imperial Petroleum Inc. announced that it had formed a lease pool with a private group to begin acquisition of acreage on certain oil and natural gas drilling prospects in the Illinois Basin (Wilson 2012).

As we show in Table 7 there are 602 oil fields in Illinois with estimated 2.4 billion barrels of cumulative production potential (Leetaru et al. 2006). These 602 oil fields include the 43 largest oil fields in the state located in the coal-rich areas of the Illinois Basin. Because many of these fields may be reaching the end of their economic life and have depths of about 600-1500 meters, they may require new methods to boost their production rates. Among the options being considered to boost oil production in Illinois is horizontal drilling, as well as enhanced oil recovery (EOR) technology using carbon dioxide, nitrogen or surfactant plus polymer flooding of the reservoirs. 
Table 7. Illinois petroleum resources profile

\begin{tabular}{|c|c|}
\hline API Gravity & 36.8 \\
\hline Gasoline yield $^{\text {(a) }}$ & $27.50 \mathrm{wt} \%$ \\
\hline Estimated number of oil wells ${ }^{(b)}$ & 16,000 \\
\hline Estimated number of marginal wells ${ }^{(\mathrm{b})}$ & $90 \%$ of total oil wells \\
\hline Estimated number of oil fields ${ }^{(c)}$ & $\sim 602$ \\
\hline Unrecovered movable crude oil $^{(\mathrm{d})}$ & $4.1 \times 10^{9}$ barrels \\
\hline Recoverable proven crude oil reserves ${ }^{(\mathrm{e})}$ & $66 \times 10^{6}$ barrels \\
\hline Estimated enhanced oil recovery (EOR) potential ${ }^{(\mathrm{f})}$ & $(632-979) \times 10^{6}$ barrels \\
\hline Estimated cumulative production potential $^{(\mathrm{c})}$ & $2.4 \times 10^{9}$ barrels \\
\hline 2009 oil production ${ }^{(\mathrm{e})}$ & $9.1 \times 10^{6}$ barrels \\
\hline
\end{tabular}

(a) Data from M. F. Scott, Illinois Geological Survey (private communication); (b) Lewis and

Bergeron 2010; (c) Leetaru et al. 2009; (d) IOGA 2011; (e) US-EIA 2011; (f) Finley et. al. 2010.

Of course application of artificial intelligence and expert systems (Gharbi et al. 2005) would be also necessary for a more efficient petroleum exploration and production. Some limited test results from the oil fields using carbon dioxide injection for bringing the reservoir to minimum miscibility condition (Benmekki and Mansoori 1986) for 31-41 days, indicated an improvement in oil recovery from 3 to 60 barrels of oil per day in a single well. Another oil well at the Manttoon field in Illinois showed a similar progress in oil recovery from 9 to 45 barrels a day. Out of the 602 individual oil fields identified in Illinois, 43 contained at least one reservoir that satisfies minimum criteria for carbon dioxide miscible flooding (Leetaru et al. 2006). The overall estimated enhanced oil recovery (EOR) potential for Illinois is estimated at 632 - 979 million barrels (Finley et. al. 2010). Currently, the safest approach for commercial scale exploitation of oil in the Illinois Basin, without compromising the integrity of the coal mines is through the use of horizontal and directional drilling. The horizontal and directional drilling technologies results in drilling of fewer wells in the oil fields, while reducing the risk of penetrating a coal mine.

Below we report recent enhanced oil recovery projects at some of the oil fields in Illinois. These include Loudon Oil Field in Fayette County, Markham City North Oil Field in Jefferson and Wayne Counties and Lawrence oil Field in Lawrence County.

Since its discovery in 1937, the Loudon oil field in Illinois has an estimated cumulative production of 400 million barrels of oil (ARI 2006). In March 2007, Midwest Geological 
Sequestration Consortium led by the Illinois State Geological Survey (ISGS), together with the Indiana and Kentucky Geological Surveys and industry partners, including Petco Petroleum Corp., conducted the first enhanced oil recovery pilot study in Loudon Field, in Fayette County in Illinois (Finley 2007a). The pilot formation was the Cypress Sandstone with average permeability of $31 \mathrm{mD}$ and average porosity of $16 \%$. The Loudon field test involved the injection of 40 metric tons of $\mathrm{CO}_{2}$ in gaseous state into a producing well, at a depth of approximately 475 meters. The $\mathrm{CO}_{2}$ injection continued for 3-5 days at the rate of 5-10 metric tons per day (MGSC 2011). The gas was allowed to mix and dissolve in the oil for approximately one week, before placing the well back on production to measure the amount of petroleum fluids produced. After the 1-week soaking period, daily oil production initially increased from 2 to $8 \mathrm{bbls}$ oil/day (or fourfold) for a few days, but subsequently decreased to 5-6 bbl/day with sustained oil rate of 1-2 bbls oil/day (Finley 2007b). Although the initial injection volume target was just 40 metric tons of $\mathrm{CO}_{2}$, it was a critical first step in testing geological sequestration and EOR in the Illinois Basin (Finley 2007a).

In February 2012, Strategic American Oil Corporation (SAOC) made an announcement that it had begun water injection at its V. People No. 1 well located at Markham City North Oil Field in Jefferson and Wayne Counties in Illinois. The location of this pilot project is near the center of the potential water flood area which is surrounded by additional leasehold held by SAOC and its partner. From 1943-2009, the Markham City North Oil Field produced an estimated 1,381,300 barrels of oil during the primary phase of production. However, it is believed that a significant amount of oil still remains in the reservoir which a portion is recoverable using water flooding. For several years, similar water-flood projects close to the location of this pilot project have performed well, with some reporting secondary to primary recovery ratio of 1 to 1 . Hence, there is anticipation that this project may yield potential gross recoverable reserves in excess of one million barrels of oil. The results from this pilot phase may be used to determine if further water flood development plans for the entire field would be productive (Schor and Foy, 2012).

Oil production at the Lawrence oil field in Illinois started in 1906. Since then over 410 million barrels of oil have been produced by several companies in this field. In April 2012, DOE reported that enhanced oil recovery was successfully used to boost oil production in excess of its peak (by more than 300\%) from a well located in Lawrence oil field in Illinois. The Lawrence 
oil field well production was increased from 16 barrels per day to between $65-75$ barrels per day, using an innovative alkaline surfactant polymer (ASP) flooding technique. According to the DOE, the ASP flooding raised the overall oil cut in the 15-acre project area from $1 \%$ to $12 \%$. The DOE sponsored project was operated by Rex Energy Corporation headquartered in State College, in Pennsylvania. The project was an integral part of a larger effort in progress at the ISGS supported by DOE's Fossil Energy Office. Because of the oil potential in this field, Rex Energy may expand testing to cover another 58-acre portion of the field. The company apparently plans to invest in ASP flooding technology on 351 acres of the field just south of the current operations in 2013. Currently, ISGS is characterizing the Mississippian Cypress sandstone reservoirs, as well as the Pennsylvanian Bridgeport sandstone underlying Lawrence field. This project aims to define the remaining oil reserves, with the view to projecting how additional oil could be economically recovered. While the two formations are the most prolific ones in Illinois, they are structurally complicated. As a result, ISGS is expecting that the ASP flooding technique could be used to recover the extra 130 million barrels of oil estimated to be technically recoverable at the Lawrence oil Field. The original oil in place in the reservoirs of Lawrence oil Field was estimated at one billion barrels. The success of the ASP technology could be extended to similar oil fields in US (Snow 2012; Jikich 2012).

\subsection{Petroleum transportation and refining in Illinois}

The world's first and largest multinational corporation (Standard Oil of Ohio) became established in Ohio in 1862. In 1890, the company set up an oil-marketing organization (Standard Oil of Illinois) in Chicago, and later owned the majority shares of P.C. Hanford Oil Co., an Illinois company established in 1861 dealing in standard illuminating and lubricating oils, axel grease, white lead and various varnishes (Andrea 1886; US-DOJ 1909). Standard Oil of Illinois was subsequently purchased by Standard Oil of Indiana. But following an anti-trust law suit in 1911, Standard Oil was forced to splinter into several subsidiaries. The refined oil from Standard Oil of Indiana refinery located outside Whiting in Indiana along the border with Chicago was transported to Chicago and other Midwestern cities through two pipelines originating in Lima, Ohio. Also, oil from Standard Oil of Indiana was transported by land using the railroad terminal belonging to the Chicago \& Calumet Terminal Railroad. In 1985, the 
Standard Oil Company in Indiana changed its name to Amoco Corporation with headquarters in Chicago. But in 1998, the company merged with British Petroleum and was renamed as BPAmoco plc, a name which was maintained till May 2008, when company changed the name to BP plc (Grant 2007).

Currently, Illinois leads the Midwest in crude oil refining capacity with four refineries combining to produce 915,000 barrels per day (US-EIA 2011). Two of these refineries are ExxonMobil in Joliet and Citgo in Lemont all near Chicago; one is from ConocoPhillips in the Illinois suburb of St. Louis, and the other is from Marathon Petroleum Company in Robinson near the Indiana border with Chicago. However, none of these refineries process any meaningful amount of Illinois petroleum. Instead, approximately $67 \%$ of the crude oil produced in Illinois is processed at CountryMark Refinery in Mt. Vernon, Indiana, while the balance is refined in Michigan and Ohio (IOGA 2009).

Illinois is a key transportation hub for crude oil and natural gas for North America because it is centrally located and has well-developed pipeline infrastructure. Illinois refineries rely on crude oil from Canada and the U.S. Gulf Coast, with much of the oil transported from Canada. Much of the Canadian heavy crude oil imported to Illinois is refined and consumed in the state, especially in transportation and industrial sectors, or transported to other states after being refined. Illinois imports more Canadian crude oil than any other state in the U.S (Grossman 2011). In 2007, Illinois petroleum import from Canada totaled $\$ 12$ billion of crude oil and \$91 million of refined products (Grossman 2011).

\subsection{Petroleum products consumption in Illinois}

Figure 8 shows the profiles of crude oil production and consumption in Illinois. In 2007, Illinois consumed about 261 million barrels of petroleum at the cost of $\$ 26.43$ billion, representing $55.5 \%$ of the total energy expenditure by the state. These included 49.29 million barrels of distillate fuel oils, 29.57 million barrels of jet fuel, 21.1 million barrels of liquefied petroleum gas (LPG), 124.28 million barrels of motor gasoline (includes fuel ethanol blended into motor gasoline), 133,000 barrels of residual fuel oil and others (Includes asphalt and road oil, aviation gasoline, kerosene, lubricants) (U.S EIA 2011). 


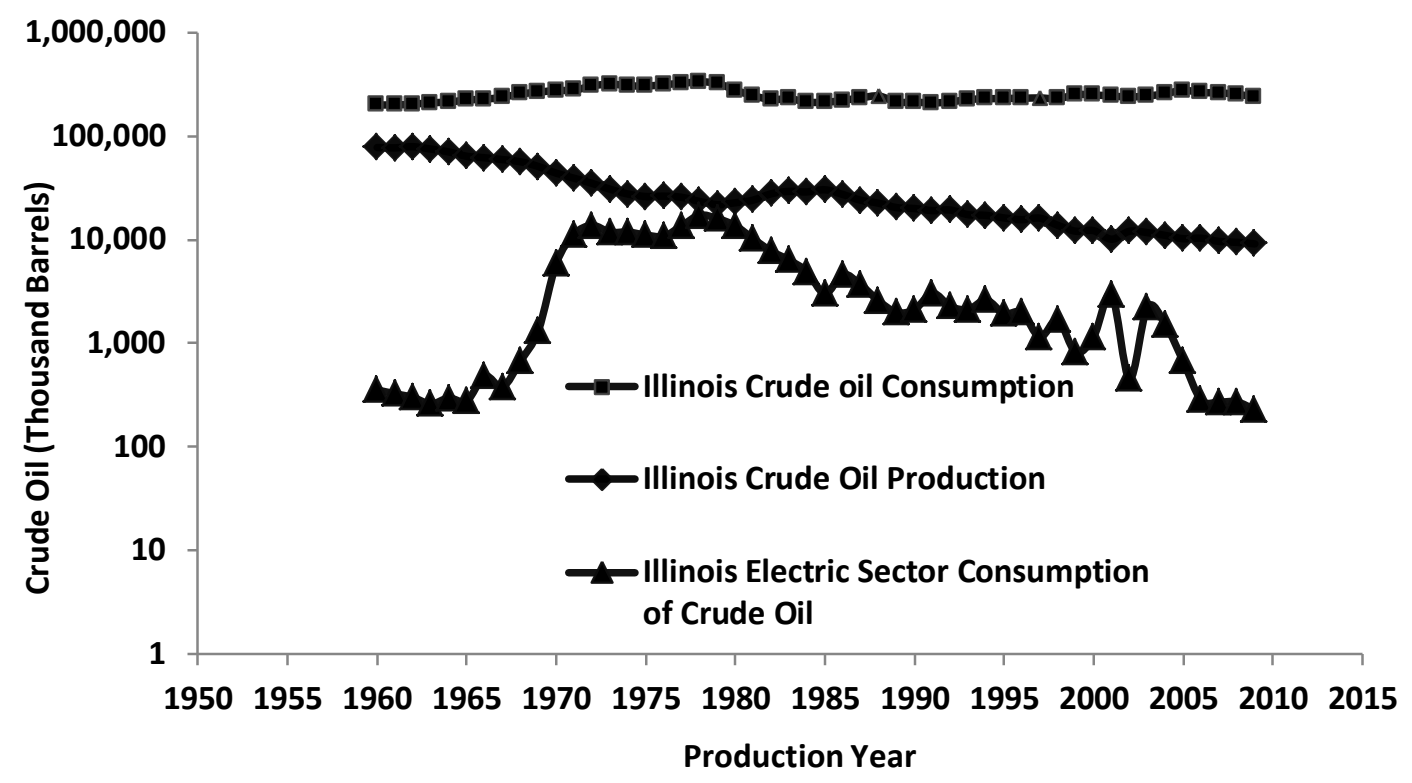

Figure 8. Profiles of petroleum fuel production and consumption in Illinois (Data from US-EIA 2011)

According to Figure 8, consumption of petroleum in Illinois has increased appreciably while petroleum production in Illinois has decreased even with bigger rate in the period of 1960-2009. The use of petroleum for electric power generation in Illinois has been a function of the price of petroleum as compared with gas and coal. As can be seen in Figure 8, in recent years the amount of petroleum fuel used for electricity generation in Illinois is not significant. For example, in 2007 the Illinois electric energy sector consumed only 272,000 barrels of petroleum in the form of residual fuels, distillate fuel oils and petroleum coke (U.S EIA 2011).

In Table 8, we report the consumption of various petroleum products in Illinois in commercial, industrial, transportation, and residential sectors in 2007.

Table 8. Consumption of various petroleum products (in million barrels) in Illinois in commercial, industrial, transportation, and residential sectors in 2007 (Data from US-EIA 2011)

\begin{tabular}{|c|c|c|c|c|c|c|}
\hline Sector & $\begin{array}{l}\text { Distillate } \\
\text { fuel oils }\end{array}$ & Jet fuel & LPG & $\begin{array}{l}\text { Motor } \\
\text { gasoline }\end{array}$ & Kerosene & $\begin{array}{l}\text { Residual } \\
\text { fuel oils }\end{array}$ \\
\hline Commercial & 0.744 & 0 & 0.699 & 0.240 & 0.036 & 0 \\
\hline Industrial & 8.65 & 0 & 14.74 & 1.79 & 0 & 0.085 \\
\hline Transportation (a) & 39.48 & 29.57 & 0.340 & 122.24 & 0 & 0.037 \\
\hline Residential & 0.155 & 0 & 5.33 & 0 & 0.052 & 0 \\
\hline
\end{tabular}

(a) The Illinois transportation sector also consumed 78,000 barrels of aviation gasoline (used in cylinder-pistonengine aircraft) in addition to distillate fuel oil. 
According to Table 8, the Illinois transportation sector in 2007 consumed most of the petroleum fuels with 39.48 million barrels of distillate fuels, 29.57 million barrels of jet fuels and 122.24 million barrels of motor gasoline. The transportation sector also consumed 78,000 barrels of aviation gasoline in addition to jet fuel and motor gasoline in 2007. The industrial sector in Illinois is the major consumer of LPG and residual fuel oils and the commercial sector is the least consumer of petroleum products.

In Table 9, we compare the total annual and per capita consumption of petroleum products in Illinois, California, New York and Texas in 2007.

Table 9. Comparison of petroleum products consumption (in million barrels) and barrels per capita (in parenthesis) in Illinois with the three other major states in the United States (California, New York and Texas) in 2007 (Data from US-EIA 2011 and the U.S. Census Bureau)

\begin{tabular}{|l|l|l|l|l|l|l|}
\hline State & $\begin{array}{l}\text { Distillate } \\
\text { fuel oils }\end{array}$ & Jet fuel & LPG & $\begin{array}{l}\text { Motor } \\
\text { gasoline }\end{array}$ & Kerosene & $\begin{array}{l}\text { Residual } \\
\text { fuel oils }\end{array}$ \\
\hline Illinois & 49.29 & 29.57 & 21.10 & 124.28 & 0.088 & 0.133 \\
& $(3.83)$ & $(2.30)$ & $(1.64)$ & $(9.66)$ & $(0.007)$ & $(0.010)$ \\
\hline California & 99.02 & 110.79 & 11.51 & 380.78 & 1.562 & 39.68 \\
& $(2.62)$ & $(2.94)$ & $(0.305)$ & $(10.10)$ & $(0.005)$ & $(1.06)$ \\
\hline New & 78.85 & 19.98 & 7.35 & 139.14 & 0.183 & 28.98 \\
York & $(4.05)$ & $(1.03)$ & $(0.378)$ & $(7.15)$ & $(0.080)$ & $(1.49)$ \\
\hline Texas & 144.54 & 75.41 & 433.29 & 290.61 & 0.052 & 32.67 \\
& $(5.63)$ & $(2.94)$ & $(16.88)$ & $(11.32)$ & $(0.002)$ & $(1.27)$ \\
\hline
\end{tabular}

According to Table 9, Illinois is a major consumer of petroleum products in most categories and in per capita consumption except for residual fuel oil.

\section{NATURAL GAS}

\subsection{Natural gas production in Illinois}

Presently, Illinois is not a major producer of natural gas as shown in Figure 9. The 2009 production estimate of dry natural gas from the Illinois Basin was $40.83 \times 10^{6}$ standard cubic meters (U.S. IEA 2011). 


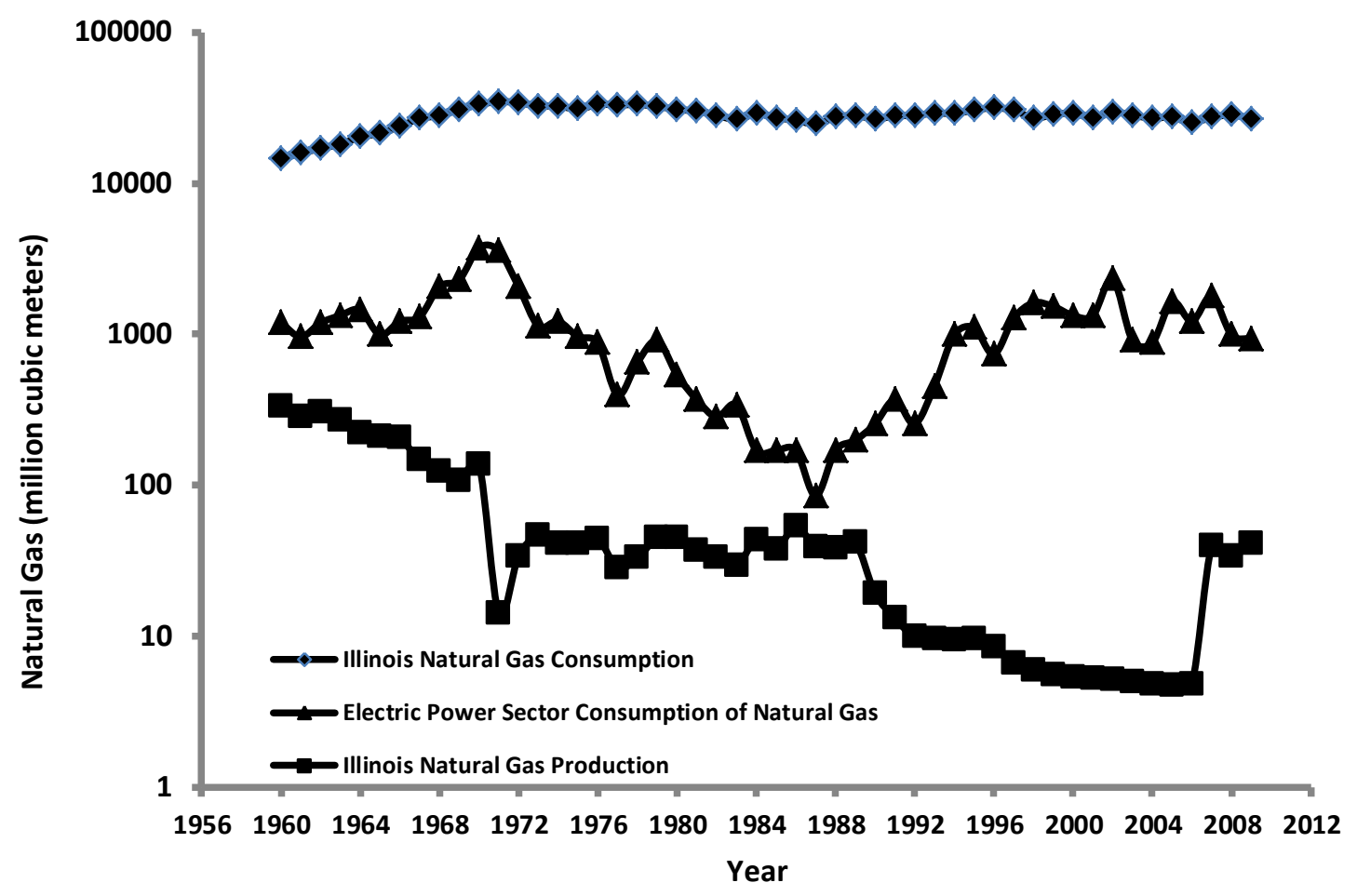

Figure 9. Illinois natural gas production and the electric power sector consumption (Data from U.S IEA 2011)

As a result, the natural gas for household use and electric power generation in Illinois is purchased from the U.S. Gulf Coast, U.S. midcontinent regions, Western Canada, Colorado and Wyoming. From these locations the gas is transported through major pipelines to the Illinois natural gas market centers (Chicago Hub and ANR Joliet Hub). These centers also serve as major hubs for natural gas distribution in North America.

In 2009, the electric power sector in Illinois consumed $934 \times 10^{6}$ standard cubic meters of natural gas (see Figure 9). The residential sector consumes most of the natural gas $\left(12.46 \times 10^{9}\right.$ standard cubic meters in the year 2009) imported to Illinois, with more than $80 \%$ of Illinois households relying on the fuel as their primary energy source for home heating, etc.. To meet the winter peak demand, Illinois stores natural gas in underground natural gas storage facilities as described below.

In Figure 10, we show the Illinois natural gas electric power price estimates for the period 1984-2011. 


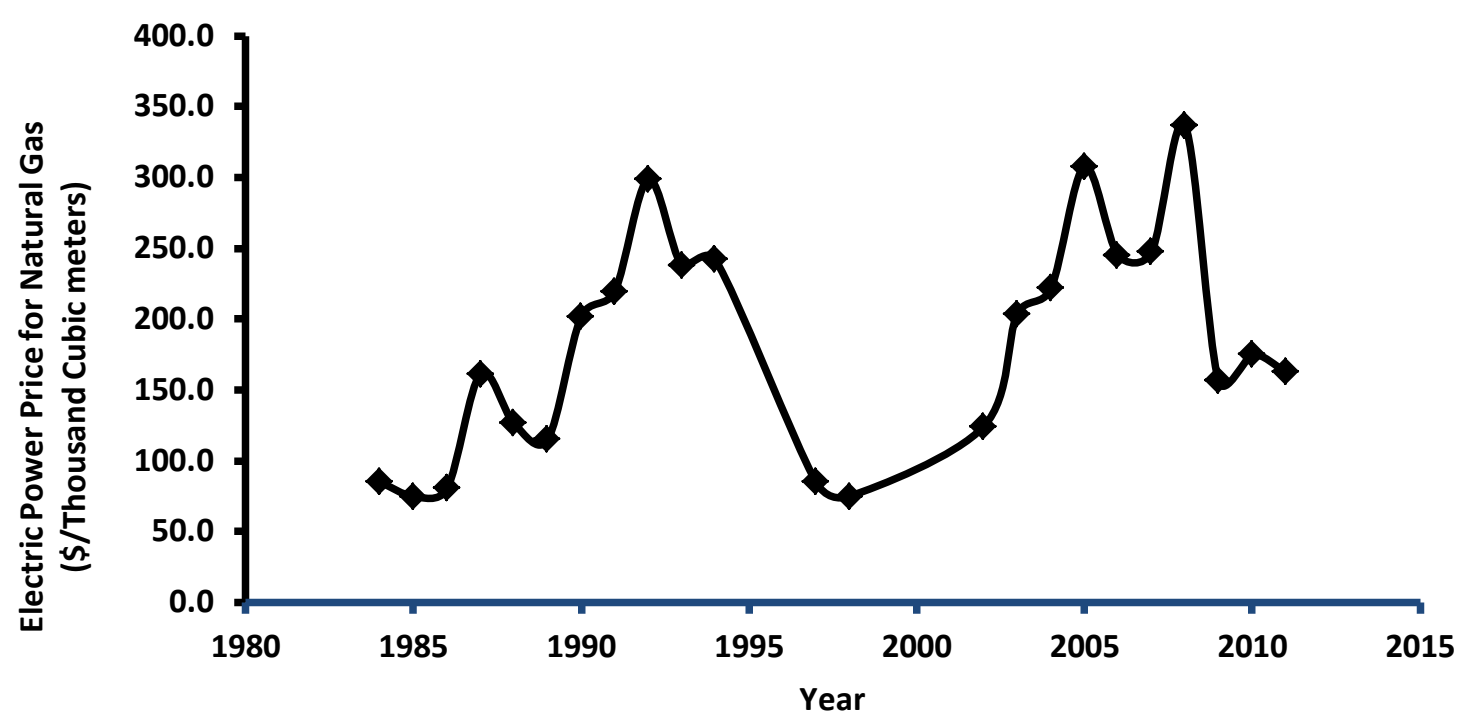

Figure 10. Illinois natural gas electric power price, 1984-2009 estimates (Data from U.S IEA 2011). Sharp price decline after 2008 is due to increasing production of shale gas in the United States.

The declining natural gas price from 2008 to 2009 shown in Figure 10 was due to increasing consumption of shale gas produced in other parts of US, as Illinois had not started producing shale gas. It is projected that shale gas production in the U.S. will represent about $20 \%$ of the U.S. natural gas consumption by the year 2020 (US-EPA 2010). Illinois natural gas reserve is currently unknown, but Illinois enhanced coal-bed methane (ECBM) potential in the Illinois Basin is estimated at $(76.46-277.51) \times 10^{9}$ standard cubic meters (Finley et. al. 2010). ECBM is a method of producing additional coal-bed methane from a source rock, as is the enhanced oil recovery applied to petroleum fields.

\subsection{Shale gas exploitation in Illinois Basin}

Recent estimates indicating large quantities of natural gas reserves and resources in shale formations have resulted in a renewed interest in natural gas as a relatively low carbon energy option. Shale gas is extracted through hydraulic fracturing (fracking). Fracking involves highpressure injections of water, chemicals and sand into shale formations to open seams that enable hydrocarbons to flow. Through this process, millions of gallons of water mixed with additives 
are left in the ground, which could lead to pollution of groundwater aquifers. Furthermore, it has been claimed that shale gas emissions of greenhouse gases are even higher than the conventional natural gas emissions, and may be equal or higher than the emissions caused by using coal or petroleum (Howarth et al. 2011).

Some experts in the oil and gas business have cautioned investors about the discouraging results of data coming from the shale wells (Urbina 2011). These developments, in addition to the recent major British Petroleum (BP) oil spill disaster in the U.S Gulf coast have raised serious questions about the use of Illinois Basin shale natural gas as replacements for coal in Illinois power plants.

Based on advances in horizontal well drilling, hydraulic fracturing and recent high gas prices, Illinois policymakers passed a bill (SB 0664) in November 2011, allowing hydraulic fracturing (fracking) in Illinois. This bill would require owners of shale drilling companies to submit specific information about their fracking plans to the Illinois Department of Natural Resources. This information would include the geological names and description of the wells, nature of additives used in the hydraulic fluid, and the depth of the formation where the fluid is applied. The bill could also make it illegal to apply any volatile organic compounds like ethyl benzene, benzene, toluene and xylene, including any use of petroleum distillates for the specified types of shale gas extraction based on hydraulic fracturing. Additionally, well owners would be required to declare information about the disposal of the used hydraulic fluid.

4.2.1. Shale hydraulic fracturing, its benefits and its problems: In the oil and gas industry, hydraulic fracturing is used to stimulate wellbores drilled into unconventional reservoirs, such as shale rock or coal-beds, with the view to maximizing the extraction of underground resources (petroleum and natural gas)(US-EPA 2010). Hydraulic fracturing allows the production of natural gas and oil from subterranean natural reservoirs, generally at a depth of 1,500-6,000 meters below the surface of the earth. Hydraulic fracturing wells are drilled either vertically all the way or first vertically and then horizontally or directionally (Cardott 2008). Vertical wells may reach depths of $300-2,500$ meters, but horizontal sections of the well may reach thousands of feet away from the production pad on the surface. Hydraulic fracturing is required for wells drilled in low permeability reservoir rock to insure permeability (see Figure 11). 


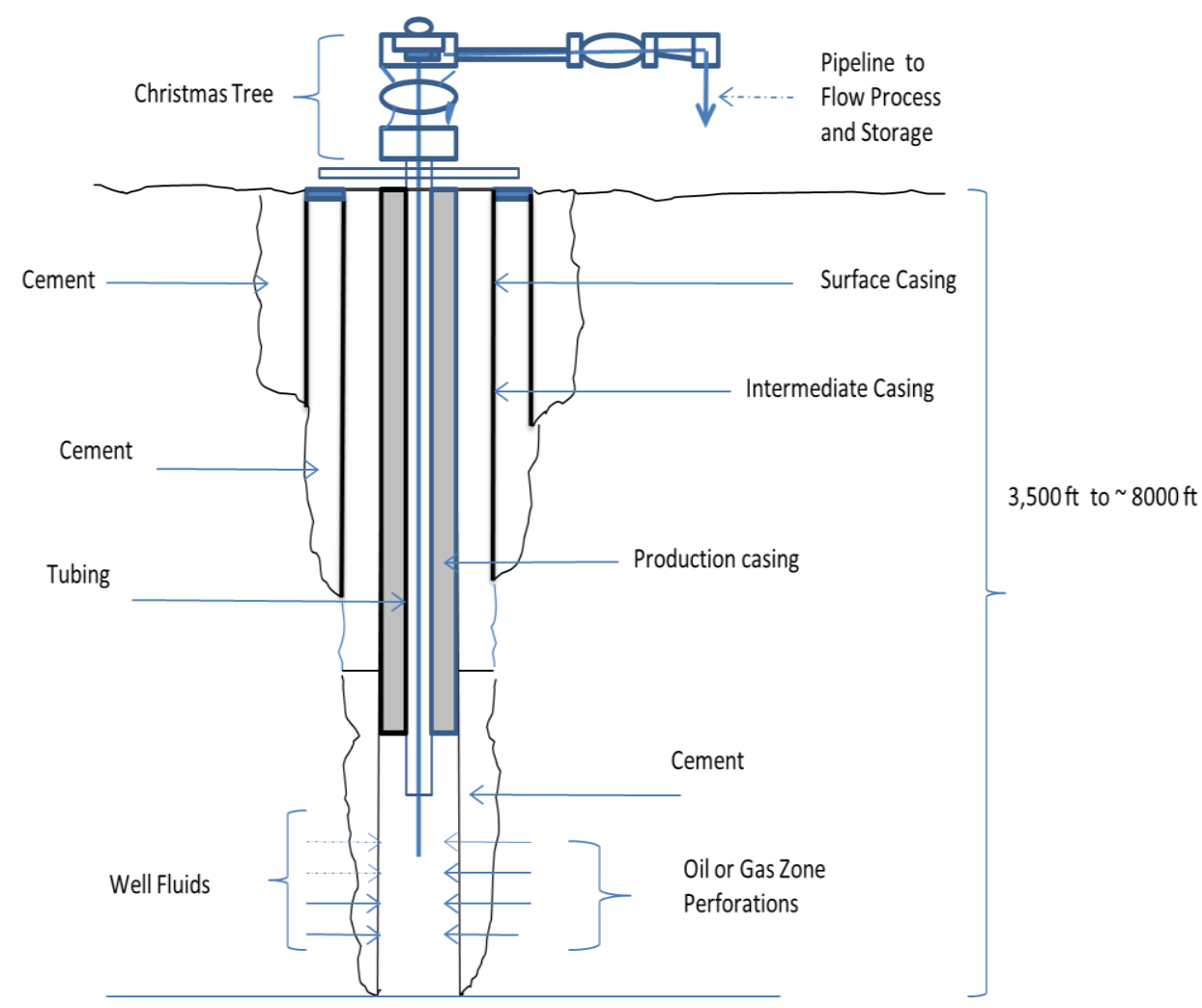

Figure 11. Single-stage hydraulic fracturing (Arthur \& Seekins 2010)

According to some estimates, hydraulic fracturing has increased the US recoverable reserves of petroleum by at least $30 \%$ and of natural gas by approximately $90 \%$ (Smith \& Montgomery 2010). The types of equipment used for hydraulic fracturing in the oil and gas industry are generally slurry blenders, combined with high pressure and high volume fracturing pumps (powerful triplex, or quintiplex pumps) and a monitoring unit. Fracture propagation during stimulation is monitored using seismic acoustic fracture mapping, tiltmeter measurements and treatment pressure analysis. The auxiliary equipment consists of high pressure treating iron, fracturing tanks, a chemical additive unit, low pressure pipes and gauges for flow rate, fluid density, and pressure. The operating pressure of the fracturing equipment is approximately $15,000 \mathrm{psi}(10,3421 \mathrm{KPa})$ at injection rates of up to 100 barrels per minute.

The hydraulic fracture is created by pressurizing fracturing fluid through the wellbore into the geologic formation. The nature of additives in fracturing fluid will enhance the fractures through chemical and physical interactions with the wellbore rocks. The fluid is pressurized at a rate high enough to raise the downhole pressure to a value greater than the fracture gradient of the formation rock. This will cause the geologic formation to crack. The crack is then 
propagated as more fluid enters the rock. To keep the fracture open, a proppant (sieved round sand or ceramic beads) is injected into the fracture before releasing the pressure. This allows the escape of gas from the fracture into the well.

Approximately $15-30 \%$ of the fracturing fluids are recovered from the well to the surface (Arthur and Seekins 2010). Hydraulic fracturing is normally recommended to be performed in short durations of time away from the shallow underground source drinking waters (Arthur et al. 2008; Arthur and Seekins 2010). Extra protection is provided using multiple casing strings and stringent construction requirements. For the process to be cost-effective, it is important that all fractures created remain in the targeted zone. Fracturing of horizontal wells require 3-5 million gallons of water, normally delivered by trucks or a temporary pipeline or from stored tanks, or local or centralized impoundments (Arthur and Seekins 2010). For high volume hydraulic fracturing operation, a comprehensive up-front modeling is used for designing stimulation jobs to ensure safety.

The components of a fracturing fluid are proppant, water and additives. The selection of additives depends on the type of wellbore and the nature of the geologic formation. They generally may include acids, biocides or disinfectants, compressed gases, corrosion inhibitors, crosslinkers, friction reducers, foams, gels, gelling agents, iron control/stabilizing agents, oxygen scavengers, $\mathrm{pH}$ adjusting agents, scale inhibitors, and surfactants.

The environmental and human health risk factors linked with hydraulic fracturing include contamination of ground water, risk to air quality, migrating chemicals including hydraulic fracturing chemicals to the surface, and potential improper waste disposal (US-HR 2011). The US Congress asked the US-EPA office of Research and Development to carry out a study on the relationship between hydraulic fracturing and drinking water resources (Arthur and Seekins 2010). The US-EPA study areas extends to the source of water as regards the quantity and quality, what chemicals are let into the well bore, what are the nearby geological and manmade features, waste water and how it is handled; the factors that influence chemical choice and operating conditions and how fluids are handled on and around the well pad (US-EPA 2010). In March 2010, the US-EPA announced its intention to conduct the study in response to the request from the Congress. In November 2011, the US-EPA announced its final research plan on hydraulic fracturing. The initial research results and study findings are expected to be released to the public in 2012 and the final report to be delivered in 2014 (US-EPA 2011). 
From 2005 to 2009 , it was reported that 14 companies who render services to the oil and gas industries used more than 2,500 hydraulic fracturing products containing 750 chemicals (U.S HR 2011). During this period of time, 780 million gallons of hydraulic fracturing products were used, excluding the water added at the well site. Among the chemicals used were some harmless compounds like salt and citric acid, and interestingly, some unanticipated compounds such as instant coffee and walnut hulls. The chemicals used included benzene, lead, methanol (applied in 342 hydraulic fracturing fluids cases), isopropyl alcohol (applied in 274 cases), 2-butoxyethanol (applied in 126 cases), and ethylene glycol (applied in 119 cases). While benzene and lead are considered toxic, methanol is listed as a potential candidate for regulation under the Safe Drinking Water Act (US-HR 2011). At least, one of the service companies involved in the high volume hydraulic fracturing business was subpoenaed by the US-EPA before the company declared the composition in its products (US-EPA 2010). Because of this a number of lawmakers are arguing that some companies may be hiding certain information about their products which could be harmful to the environment (US-EPA 2010).

4.2.2. The New Albany Shale gas in the Illinois Basin: The New Albany shale rock is the only natural gas bearing shale rock identified in Illinois. For over a century, the New Albany Shale located in the Illinois Basin of Southeastern Illinois is known of its hydrocarbon deposits. However, lack of technical know-how has hampered efforts to harness this energy resource on the commercial scale (Cluff \& Dickerson 1982). The shale rock was named after its outcrop New Albany in Indiana. The shale covers much of Illinois, Western Kentucky and Southwestern Indiana. The elevation of the top of the New Albany Shale stretches from nearly 230 meters above sea level near the outcrop, to over 1,370 meters below sea level in southeastern Illinois. The formation estimated area in the Illinois Basin is 137,269 kilometers square $(53,000$ square miles) and has its thickest depth of over 140 meters in southeastern Illinois and western Kentucky (kentuckynaturalgas.com/New_Albany_Shale.html). The estimated gas-in-place of the New Albany Shale is $(2.44-4.53) \times 10^{12}$ standard cubic meters (GTI 2009; Dahaghi \& Mohaghegh 2009; Mastalerz et al. 2010).

In mid-1976, Illinois State Geological Survey undertook a comprehensive study of the geology and geochemistry of the New Albany Shale, to evaluate its potential for shale gas and other hydrocarbon compounds. Through organic geochemistry we can find the underground 
existence and nature of petroleum and natural gas (Carpentier et al. 2007). Subsequent research work conducted in 1982 indicated that the most favorable place in Illinois for shale gas resources, based on four major geologic criteria (depositional facies, shale thickness, thermal maturation and known faulting and fracturing) is the 19-county area of Southeastern Illinois (Cluff and Dickerson 1982). In 1979, the first quantitative assessment data of gas content of core samples from New Albany Shale gas wells in Wayne County of Illinois became available. In addition to the $2.44-4.53 \times 10^{12}$ standard cubic meters of shale gas-in-place, in 2007 , the U.S. Geological Survey estimated that the Illinois Basin contains the following quantities of undiscovered, but technically recoverable oil and gas resources: a mean of $214 \times 10^{6}$ barrels of oil, a mean of $132 \times 10^{9}$ standard cubic meters of natural gas and a mean of $24 \times 10^{6}$ barrels of natural gas liquids (US-GS 2007).

The New Albany Shale is the most carbon-rich geologic formation among all the gas shale basins in the US. The formation is of Devonian and Mississippian age and is a major source of hydrocarbons. The formation was deposited under anoxic marine conditions and is made up of brown, black, and green shale with minor beds of dolomite and sandstone. The organic-rich content of the New Albany Shale is $4 \%$ by weight and Pyrite is a common accessory mineral. Also present in the black shale layers are phosphorus, heavy metals and uranium which results in an unusually high radioactivity level (Barron \& Ettensohn 1981). The formation is similar to the Ohio Shale of Ohio and Eastern Kentucky, the Antrim Shale of the Michigan Basin, and the Chattanooga Shale of Tennessee and central Kentucky. The New Albany Shale consists of the following stratigraphic (rock layering) members with distinctive physical properties: the Blocher which is slightly calcareous and dolomites black shale (brownish-black to grayish-black), the Selmier (greenish-gray to olive-gray shale), the Morgan Trail (brownishblack to olive-black fissile siliceous pyritic shale), the Camp Run (a greenish-gray to olive-gray shale interbedded with brownish-black shale), the Clegg Creek (a brownish black pyritic shale is the most organic-rich portion of the formation), and the Ellsworth (composed of a lower part of interbedded brownish-black shale and an upper part of greenish-gray shale) (Stevenson et al. 1981).

To access gas production potential of New Albany Shale, it is important to know the correct properties of the reservoir for appropriate completion strategy of the well to increase gas recovery. These properties are organic richness, thickness, thermal maturation, permeability, 
porosity, pore pressure, gas-in-place, mineralogy and brittleness. In what follows, these characteristics of New Albany Shale are reported.

\subsubsection{Properties of New Albany Shale:}

Organic richness: In general, the organic carbon content of shale rock is related to the hydrocarbon-bearing potential. Black shale enriched with elements, such as arsenic, molybdenum and nickel is known to contain hydrocarbons (Cluff et al. 1980). The total organic carbon (TOC) in the New Albany Shale is quite variable, ranging from near $0 \%$ by weight in greenish-gray beds to $25 \%$ by weight in brownish-black organic-rich beds, and averaging about $4 \%$ by weight, which is comparable to other shale of the same family (Cluff et al. 1980; GRI 1994).

Shale thickness. There is a close relationship between areas of thick black shale accumulation and gas production in gas shale basins. Thick black shales normally indicate the presence of rich hydrocarbon reservoirs. The Illinois Basin has a couple of broad regions with moderately thick shale accumulation (Cluff et al. 1980). The thickness of the New Albany Shale is more than 90 meters in parts of southeastern Illinois, western Kentucky and southwestern Indiana, including west-central Illinois. But the shale measures less than 30 meters in thickness towards the margins where it is bounded by the Cincinnati Arch in the east, the Kankakee Arch in the northeast, the Wisconsin-LaSalle Arch in the north, the Mississippi River Arch in the northwest, the NE Missouri Arch and the Ozark Dome in the West and the Pascola Arch in the south (Lazar and Schieber 2004).

Thermal maturation: Thermal maturation is the time-temperature dependency of the transformation of sedimentary organic matter to mobile hydrocarbons. Most hydrocarbons, including oil and natural gas evolved from thermal maturation of sedimentary organic matter. Therefore, measurement of thermal maturation of the organic matter in the shale samples (vitrinite reflectance) allows identification of oil and gas locations in the geologic formations (Cluff et al. 1980). In Southeastern Illinois in the Illinois Basin, the vitrinite reflectance values

for the hydrocarbon deposits are locally well over $0.80 \%$ (GRI 1994). The deepest part of the 
Illinois Basin in Hamilton and Wayne Counties, in Illinois has average vitrinite reflectance values between 0.63 and $0.76 \%$ (GRI 1994). The recent vitrinite reflectance reported from the New Albany Shale in the Illinois Basin of Kentucky ranges from 0.55 to $1.01 \%$. These recent data agree with all the previous data reviewed, thus placing the New Albany Shale in the Illinois Basin largely in the oil window (i.e. Type II to Type II-III kerogen range) (GTI 2009).

Permeability: Permeability is defined as the capacity of rock to allow fluids to pass through it. The most commonly used unit of permeability is the Darcy, which may be defined as the rate of flow (in milliliters per second) of a fluid with a viscosity of one centipoise through a porous medium with cross-sectional area of one square centimeter, under a pressure gradient of one atmosphere $(760 \mathrm{~mm} \mathrm{Hg}$ ) per centimeter. The measured permeability of the New Albany Shale in the Illinois Basin ranges from 1.0 - 100 micro-Darcies (GTI 2009).

Porosity: Porosity is defined as the capacity of a rock to contain fluids, which is often expressed as a percentage ratio of the total pore volume to the rock or bulk volume. The three factors that can influence the porosity of shale rocks are the depth of burial, carbonate content, and organic content (Cluff et al. 1980). In the case of the New Albany Shale, most part of the total pore volume of the shale is linked with ultra-micropores with diameters less than $5 \AA$. As a result, the diffusion of gas within the ultra-micropores becomes activated and much dependent on temperature rather than pressure, and since the diffusion coefficient is a function of the temperature, this explains the low-permeability of the shale. In general, the porosity of shale rock ranges from 4 to 6 p.u. The porosity unit (p.u.) is the percentage of pore space in a unit volume of rock. The porosity of the New Albany Shale in the Illinois Basin in a core from Christian County in Kentucky ranges from 0.5 to 3.1\%, averaging $1.8 \%$ (Kalantari-Dahaghi and Mohaghegh 2011). The porosity of the New Albany Shale in the Illinois Basin in a core sample from Sullivan County, Indiana, varies from 0.6 to $9.3 \%$ and averaging 4.0\% (GRI 1994).

Pore pressure: Pore pressure is defined as the estimated amount of force exerted in the borehole by fluids or gases within the formation that has been penetrated per unit area of borehole. The estimated pore pressure is used to determine the amount of rock and fluid weight required to prevent the fluid or gas from escaping and causing a blowout or wellbore failure. As a result, 
pore pressure needs to be known to have a better understanding of subsurface environment to ensure safety in designing, drilling and constructing of gas wells). According to the data from $\mathbf{J}$ Ray Clark well in the Illinois Basin in Christian County in Kentucky, the typical pore pressure for gas well stimulation using hydraulic fracturing in the Illinois Basin was estimated as 12,410 $\mathrm{kPa}(\mathrm{GRI} 2009)$.

Gas-in-place: The prediction of recoverable gas in shale rock basins requires an accurate estimate of gas-in-place. The gas-in-place is a combination of the free gas within the pores and natural fractures of the shale, including the gas adsorbed on the surface of the organic matter (kerogen) in the shale. The gas-in-place of the New Albany Shale ranges from 88.34 - 220.87 million cubic meters per kilometer square, depending on locations and depths (KalantariDahaghi and Mohaghegh 2011). The amount of free gas depends on the pressure, porosity and gas saturation and is estimated to be from 15 to $80 \%$ for most gas shale basins (Pearcy et al. 2004).

Mineralogy: Mineralogy is the study of the mineral constituents of rocks, as well as the systematic geological changes that led to the deposition of the rock. The mineralogy of these shale rocks explains whether the shale is gas bearing reservoir. The types of minerals in the New Albany Shale are quartz, clay minerals, muscovite mica, minor amounts of potassium feldspar and plagioclase (GRI 1994). In general, shale rich in swelling clay minerals and quartz is a potential source of gas reservoir of significant economic value (Nicolas and Bamburak 2009). Also shale rock rich in quartz grains enhances the brittleness of the rock, the effectiveness of reservoir fracturing techniques, and consequently the gas production rate. However, swelling clay can be detrimental to potential gas reservoirs during drilling, reservoir stimulation and gas production. The reason is that swelling clay may reduce the porosity and permeability of the shale, resulting in low gas flow. Mineralogy can also provide important clues to facilitate the planning and drilling operations of the shale because of the impact of the minerals on the drilling fluids and the drilling techniques (Nicolas and Bamburak 2009).

Natural gas content: The original gas-in-place estimates for the New Albany Shale is about $4.53 \times 10^{12}$ standard cubic meters, while technically recoverable volumes are estimated to be 
about $0.544 \times 10^{12}$ standard cubic meters. In Table 10 we report the value and/or nature of New Albany Shale properties which are discussed in this section.

Table 10. Characteristics of the New Albany Basin shale gas reservoir

\begin{tabular}{|c|c|}
\hline Property & Value/ Nature \\
\hline Mineralogy $^{a}$ & $\begin{array}{l}\text { quartz, clay, muscovite mica, little potassium } \\
\text { feldspar \& plagioclase }\end{array}$ \\
\hline Estimated Basin area ${ }^{b}$ & $112,664.48 \mathrm{sq} \mathrm{km}$ \\
\hline Depth $^{b}$ & $152.4-609.6$ meters \\
\hline Shale thickness ${ }^{\mathrm{c}}$ & $<30$ meters -90 meters $<$ \\
\hline Net thickness ${ }^{b}$ & $15.24-30.48$ meters \\
\hline Depth to base of treatable water ${ }^{b}$ & 121.92 meters \\
\hline $\begin{array}{l}\text { Rock column thickness between top of pay and } \\
\text { bottom of treatable water }\end{array}$ & $30.48-487.68$ meters \\
\hline Total organic carbon ${ }^{b, d}$ & $<1-25 \%$; average: $4 \%$ \\
\hline Thermal maturation (vitrinite reflectance) ${ }^{\mathrm{d}, \mathrm{e}}$ & $0.55-1.01 \%$; average: $0.63-0.76 \%$ \\
\hline Total porosity ${ }^{\mathrm{b}}$ & $<10-14 \%<$ \\
\hline Permeability & 1.0-100 micro-Darcies \\
\hline Pore pressure ${ }^{\mathrm{e}}$ & $\sim 12,410.56 \mathrm{kPa}$ \\
\hline Total gas-in-place ${ }^{\mathrm{h}}$ & $(87.39-218.49) \times 10^{6} \mathrm{~m}^{3} / \mathrm{km}^{2}$ \\
\hline Free gas-in-place ${ }^{f}$ & $15-80 \%$ of total gas-in-place \\
\hline Gas content ${ }^{b}$ & $1.24-2.49$ std. $\mathrm{m}^{3} /$ metric ton \\
\hline Water production $^{\mathrm{b}}$ & $0.79-79.49 \mathrm{~m}^{3}$ of water/day \\
\hline Well Spacing ${ }^{b}$ & 80 acres \\
\hline Original gas in place ${ }^{b}$ & $4.53 \times 10^{12}$ std. $\mathrm{m}^{3}$ \\
\hline Recoverable Resources ${ }^{b}$ & $0.544 \times 10^{12}$ std. $\mathrm{m}^{3}$ \\
\hline Estimated initial prod. per horizontal well $(\mathrm{hw})^{\mathrm{g}}$ & $7,787 \mathrm{~m}^{3} /$ day $/ \mathrm{hw}$ \\
\hline Targeted gas prod. per horizontal well (hw) ${ }^{g}$ & $14,158 \mathrm{~m}^{3} /$ day $/ \mathrm{hw}$ \\
\hline
\end{tabular}

(a) Nicolas and Bamburak 2009; (b) Arthur et al. 2008b; (c) Lazar and Schieber 2004; (d) GRI 1994;

(e) GTI 2009; (f) Pearcy et al. 2004; (g) Durham 2008; (h) Kalantari-Dahaghi and Mohaghegh, 2011.

4.2.4. Technical challenges in hydraulic fracturing at New Albany Shale: At the New Albany Shale in the Illinois Basin, it is necessary to develop specific techniques and methods to boost gas production to commercial levels. This will require careful planning of well drilling geometries, precise formation characterization and completion practices that would ensure optimum gas recovery. Exploitation of the New Albany Shale in the Illinois Basin began in the late 1800 's, when oil exploration was at its peak. In the course of those activities, gas was detected as the drill bits pierced through the shale. However, any further development to exploit the gas foundered on several limitations, including very low permeability of the shale (Durham 
2010). Over the years, none of the data from the New Albany Shale has translated into commercial scale quantities of gas. This raised concerns about the inherent technical problems (i.e., problems arising from the use of inaccurate data about the shale, which could compromise gas well simulation designs) linked with this gas shale basin. The current New Albany gas wells are mainly from natural fractures which their estimated cost of production ranges from $\$ 1-\$ 1.8$ million for $2.84 \times 10^{6}$ cubic meters of gas/Well/year based on estimated initial gas production of 7,787.13 cubic meters per day (275 mcfd), using horizontal well with hydraulic fracture stimulation (Durham 2010). The New Albany Shale rock has extremely low matrix permeability, coupled with few open natural fractures. Therefore, proper positioning of horizontal wells relative to the dominant fracture orientation will be needed in commercial scale production of gas. In this case, the fractures may be linked through the hydraulic fracture stimulation, while exercising caution with the water bearing rocks. The water-bearing rock in the New Albany Shale is expected to be one of the major problems hampering efforts to boost gas production rate [Durham 2010].

In general, horizontal wells at the New Albany Shale basin have indicated much higher production rates than vertical wells with fractures. For example, the initial gas production rate of a typical New Albany Shale horizontal well with a lateral measurement of 762 meter $(2,500$ foot) is $7,787.13$ cubic meters per day ( $275 \mathrm{mcfd})$, reducing to 2831.68 cubic meters per day (100 mcfd) in the first 24 months of operation (Durham 2010). The peak production volume for these wells happens in the first 30 days, accompanied by a considerable gas production decline pattern following a shallow hyperbolic curve profile. The cumulative gas production over a 40year period is estimated to be $28.32 \times 10^{6}$ standard cubic meters per well. In general, it is very common to have initial high production rates, accompanied by steep declines, and the New Albany Shale wells are no exception. Also for some gas wells, it is not uncommon for the steep decline in gas production to continue for several years, before realizing any significant volumes of gas production. Nevertheless, researchers are hoping to raise the initial production rate to about 14,158.42 standard cubic meters per day, by investigating various optimum designs for fracture stimulations with different fracturing fluids. This could result in a net higher volume of gas production with cost savings, even after showing some initial decline in production rate due to technical problems. 
The advance technologies used in shale gas drilling include horizontal drilling, multistage fracturing, multilaterals drilling, simultaneous hydraulic fracturing drilling, 3-D seismic monitors and real-time microseismic monitoring (Cardott 2008). The three dimensional (3-D) high-resolution seismic imaging instrumentation allows the exploration of hydrocarbon deposits in areas with complex structures lying below complex overburden. With this instrumentation the driller of underground geologic formations can point with precision to the locations of high gas concentrations. This technique produces higher drilling success rates with improved economics of gas production. The environmental impact is also mitigated because fewer emissions and less waste are produced from drilling activities (Cardott 2008). Microseismic monitoring which is a borehole seismic technique can be used for detecting the micro-acoustic energy caused by changes in the stress of the shale rock matrix during hydraulic fracturing. The device allows accurate measurement of the hypocenter of acoustic emissions during the injection of fluids, gas, proppant, and other materials in the borehole. The device can record an image of the fractures by sensing micro-earthquakes that are caused by shear slippage on bedding planes or natural fractures adjacent to the hydraulic fracture. The microseismic data acquisition device is used to improve oil and gas production economics by enhancing reservoir productivity and reducing oil and gas well completion costs (Taleghani and Lorenzo 2011).

\subsection{Underground natural gas storage facilities in Illinois}

Illinois underground natural gas storage began in 1941, when the first known experiments were performed by Superior Oil Company at New Harmony in Indiana. In the course of these experiments, 424,753 standard cubic meters of gas was injected into a reservoir, which resulted in gas exit when the well was opened (Bond and Buschbach 1967). However, there was plenty of salt water in the gas leading to low gas flow and eventual cut off of the flow and the experiment was abandoned. In 1950, Mississippi River Fuel Corporation at Waterloo, Illinois began the first practical use of underground gas storage in Illinois. But it was not until 1952, that Natural Gas Pipeline and Panhandle Eastern Pipeline Companies began large scale projects at Herscher and Waverly, respectively (Bond and Buschbach 1967). As of 2009, Illinois ranked 
second only to that of Michigan with total underground natural gas storage capacity of $28.01 \times 10^{9}$ standard cubic meters, as can be seen from the data reported in Figure 12 (Leetaru et al. 2006).

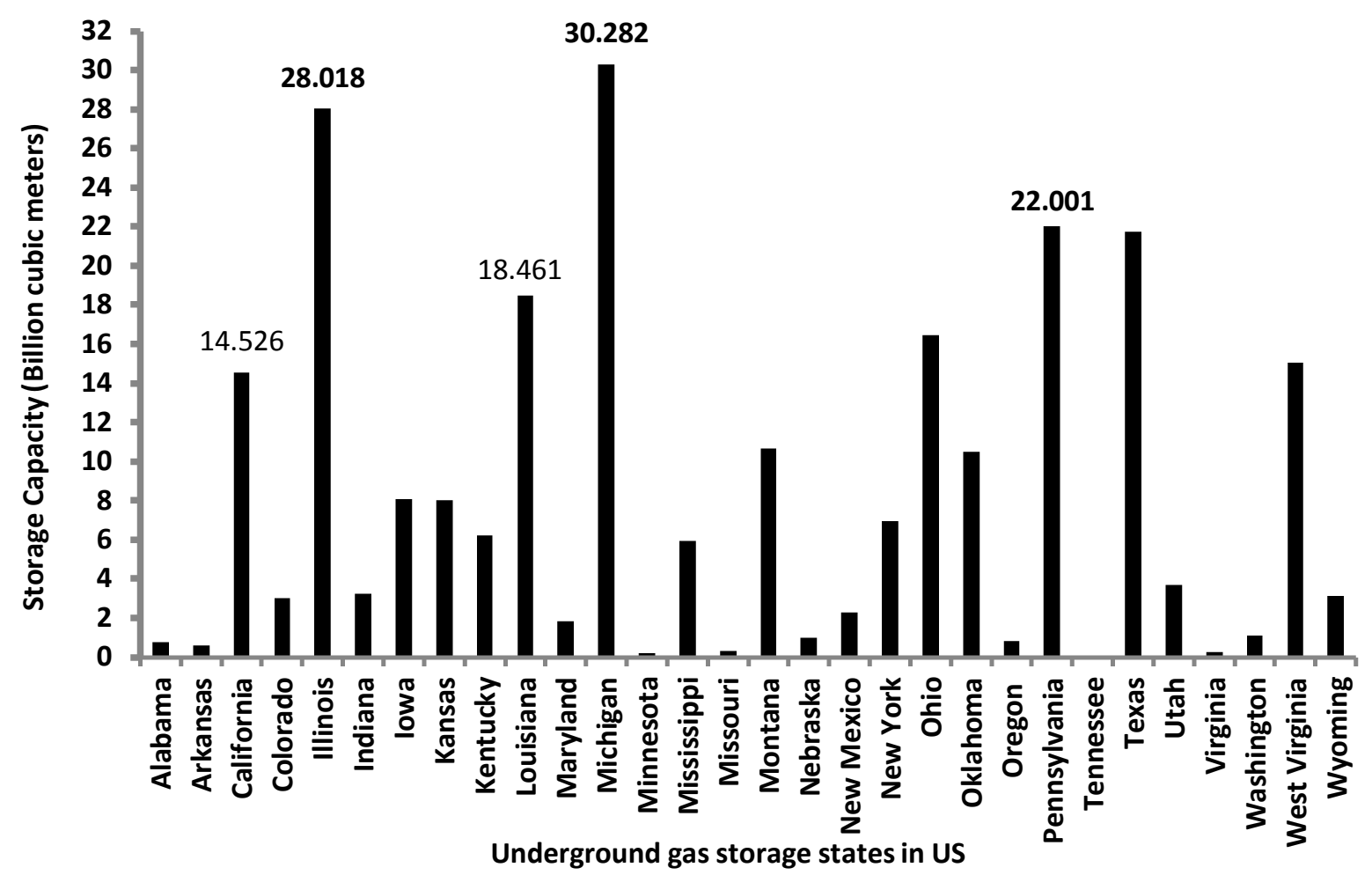

Figure 12. Comparison of Illinois gas storage capacity with the other US states that have storage facilities in 2009 (Data from U.S. EIA 2006)

The three basic types of reservoirs for underground storage of natural gas are depleted gas and oil fields, aquifers, and salt caverns. Only depleted oil and gas fields and aquifers are used in Illinois because there are more aquifers in Illinois than any other state in the United States.

An example of depleted oil and gas fields is the Herscher natural gas storage site in Illinois, owned by Natural Gas Pipeline Company (Kinder Morgan) that was part of the Trenton oil fields operating in the 1880's, but that was abandoned in early 1900's (Schill 2009). Since the 1950's the Herscher site has been used to store natural gas because the Cambrian-age sandstone makes it ideal for this purpose. 
An underground storage facility for natural gas in the Illinois Basin requires an aquifer, or a storage porous rock layer with sufficient permeability and porosity to accept and hold the gas, an impermeable caprock overlaying the storage area to prevent upward migration of gas, and a geologic trap to keep the gas from moving in a horizontal direction (Bond \& Buschbach 1967).

A reservoir that was originally filled with oil or gas, which is referred to as depleted reservoir, usually contains porous rock layers that may be used for gas storage. At high pressures gas also dissolve in liquids (Mansoori and Edalat 1996). Natural aquifers, which were originally filled with fresh or salt water are another possibility for gas storage in Illinois Basin. About $60 \%$ of Illinois natural gas is stored in salt water aquifers, while the remaining is stored in depleted gas and oil reservoirs. However, gas storage in depleted oil and gas fields represent the most widespread method of storing natural gas in large quantities (around $76 \%$ of gas storage volume) worldwide (Evan and West 2008). In Illinois, natural gas storage facilities are used to meet traditional seasonal load variations, emergency situations and hourly swings.

The underground natural gas storage facilities in Illinois are currently used for the following purposes most of which are well specified by the U.S. Federal Regulatory Commission (FERC 2004): 1-To ensure the lowest cost of natural gas purchase from gas producers by the gas storage company. 2-To provide constant gas supply to customers and meet related regulatory obligations. 3-To provide low gas prices to consumers through maintenance of specific levels of storage inventory. 4-To ensure liquidity at market centers to help control price volatility and maintain orderly gas markets. 5-To offset the reduction in traditional supplies to meet winter demand, increase the comfort inventory level of working gas or top gas; serve to offset the growing summer peak impacts from electric generation, through the injection of more gas during the shoulder months, and support electric generation loads.

Gas storage in underground storage field operations consists of several components and interdependent facilities. These include observation wells, injection and withdrawal wells, water disposal wells, dehydration facilities, gathering lines, compressors, gas measuring facilities and, at least, one major transportation pipeline for gas delivery or reception with proper design (Edalat and Mansoori, 1988). An example of underground gas storage in Illinois is the Manlove gas storage complex in northwest Champaign County, which can hold approximately $4.33 \times 10^{9}$ standard cubic meters of gas at depths of about 1,200 m (4,000 ft) (Leetaru et al. 2006). The gas is stored under about 27,500 leased acres of farmland; but there is a central location with offices, 
gas treatment facilities, pumps and pipeline connections (Leetaru et al. 2006). Natural gas is injected into the reservoir (depleted oil and gas or aquifer formation) to build up a volume of compressed gas, which can later be withdrawn through operating wells. The gas storage can be cycled between a maximum and minimum operating pressures of the reservoir. The maximum pressure is the highest operable pressure that the caprock can support, and tends to be the original pressure of the reservoir at the time of discovery (Bond \& Buscbach 1973). Below the minimum operating pressure is the cushion gas (base gas), which represents around $50 \%$ of the total gas in place in the reservoir and is physically unrecoverable gas. The working gas which can be made available to the market is the volume of gas in the reservoir above the level of base gas. The working gas capacity refers to total gas storage capacity less the base gas. The total gas in storage is the volume of storage in the underground facility at a particular time. The total gas storage capacity is the maximum volume of gas that can be stored in an underground storage facility in accordance with its design, which comprises the physical characteristics of the reservoir, installed equipment, and operating procedures particular to the site.

In the 70 's, over $16.4 \times 10^{9}$ standard cubic meters of natural gas was stored in underground reservoirs at 37 locations in Illinois. Out of this volume of gas about one third or $5.58 \times 10^{9}$ standard cubic meters was working gas and two-third or $10.93 \times 10^{9}$ standard cubic meters was cushion gas (Bond and Buschbach 1973). Out of the 37 underground reservoirs in Illinois, 29 have working gas capacity of $8.52 \times 10^{9}$ standard cubic meters, and daily withdrawal capability of $173.8 \times 10^{6}$ standard cubic meters (Tobin 2006). Out of these 29 locations, 11 are depleted gas storage sites with working gas capacity of $1.47 \times 10^{9}$ standard cubic meters and daily withdrawal capability of $23.64 \times 10^{6}$ standard cubic meters, and 18 are aquifer storage sites with working gas capacity of $7.05 \times 10^{9}$ standard cubic meters and daily withdrawal capability of $150.2 \times 10^{6}$ standard cubic meters (Tobin 2006). The remaining 8 (of the total 37) storage locations in Illinois remain inactive because gas companies can now store more gas using few storage sites than it was in the 70's, due to improved methods of storage.

In the past years, some of the aquifer storage facilities experienced leak problems and were shut down. The leaks were the result of inadequate sealing of caprock and problems associated with faulting. In Northern Illinois, the Cambrian Mt. Simon underground water-filled sand/sandstone aquifers are extensively used to store natural gas for peak seasonal usage in the Midwest. About $60 \%$ of the total gas storage inventory in Illinois is held at the Mt. Simon 
formations, which is an important supply for peak winter deliveries for Northern Illinois cities and specially Chicago (Morse 1999). Since 1968, there have been several modifications to the storage fields to meet changing market conditions. In Illinois, operators of underground gas storage facilities have added new designs and built surface and underground facilities. These changes include relocating wells within reservoirs, drilling of large diameter wells, adding coil tubing drilling, horizontal wells drilling and completing larger diameter wells. Furthermore, storage operators are adding dehydration units, compressors and new gathering lines (FERC 2004). Besides, they are employing new technology procedures to better understand reservoir geology, confinement and reservoir flow behaviors, adding new storage operational procedures, while abandoning unprofitable facilities.

Currently, there are several available new technologies that may be used to improve natural gas storage field efficiency in Illinois. One technology allows debris in the well pipe to be removed using a low/high frequency sound wave device. The device can be used to provide lasting improvements in storage wells by vibrating scales off the well pipes to unclog them. The conventional way of removing debris is by washing, injecting of acids and creating of new perforations in the well pipe (FERC 2004).

Additionally, there are innovative fracturing technologies, such as injecting high pressure liquid carbon dioxide instead of water or other liquids, to prevent clays from sticking and sealing off parts of the reservoir (FERC 2004).

For storage of large quantities of gas using the same volume of reservoir, the gas may be converted into solid clatherate, also known as gas-hydrate, (Mahajan, et al. 2007) at reservoir temperature and high pressures in the presence of water to make it more compact. The advantage is that as much as 181 standard cubic meters of natural gas can theoretically be stored in a single cubic meter of hydrate (US-DOE 2011).

Also, a gas storage facility in Sweden, called "lined rock caverns," is being studied by DOE to expand the geographic diversity of gas storage in US. The system consists of a steel tank installed in a cavern carved into the rock of a hill. Around the steel tank is a cast concrete which transfers the pressure build-up from the tank to the rock. According to DOE, although the technique is more expensive than conventional method of gas storage (in aquifers, depleted oil or gas fields or salt formations), it allows multiple injections and withdrawals of gas several times during the year, a situation which is not always practical with the other systems of gas storage. 
This could make the service cost of the "lined rock cavern," comparable to conventional storage methods. In the US, a couple of sites have already been studied as possible locations for applying the "lined rock cavern" technology. These sites include a $113.3 \times 10^{6}$ cubic meters (4 billion cubic foot) working gas facility near Atlanta, Georgia, and a $56.6 \times 10^{6}$ cubic meters (2 billion cubic foot) working gas facility near Boston, Massachusetts (U.S. DOE 2011)

\subsection{Natural gas consumption in Illinois}

Presently, natural gas is mostly for households use in Illinois. In 2007, natural gas contributed only $2.32 \%$ of the fuel used for Illinois electricity production, which could reach $31 \%$ with full utilization of the existing gas-fired electric power plants according to Wernau (2011) through more production or more import of natural gas. Other uses of natural gas in Illinois include industrial, transportation and commercial sectors of the economy (US-EIA 2011). Natural gas pricing can be very volatile, which could bring financial burden to bear on consumers.

It is believed an option for reducing carbon dioxide emissions would be to replace coalfired power plants with natural gas-fired power plants. During the early 1990s until 1996, some natural gas-fired power plants were built in Illinois to meet peak-load shaving demand and because natural gas was cheaper than fuel oil (Kaplan 2010). The Illinois natural gas-fired power plants construction boom started in 1997 and continued until 2007, when the electricity market in the United States was going through a period of deregulation. Around that period, more natural gas-fired power plants were built in Illinois by non-utility companies known as Alternative Retail Electric Suppliers, while Investor-Owned Utility companies nearly halted the construction of new power plants. The construction of the new power plants was partly motivated by the desire to reap quick financial gains from the newly deregulated power market, as well as by the cheap natural gas prices at that time. During 1998 about 16 new gas-fired power plants totaling $5,305 \mathrm{~mW}$ of capacity became operational or were being built in Illinois (Finley 2011). By the end of 1998, Illinois was a net exporter of electricity.

As of August 2000, over 50 new gas-fired power plant permits were granted in the State of Illinois or were in the pending status. Furthermore, 10 new natural gas-fired power plants were permitted by the Illinois-EPA, while 20 plants were in the permit process (Finley 2011). One example is the Exelon's Southeast Chicago Energy Project which was built in 2002. The 8- 
unit facility provides much needed peak generation to the city of Chicago during periods of high electric demand in the summer and winter months. Each unit of this power plant is rated at 44 $\mathrm{mW}$ power and runs on natural gas. According to Illinois-EPA, by the year 2005, out of the 55 proposed small size gas-fired power plants, only 22 were built, while out of the 21 proposals for larger gas-fired power plants, just 5 of them were built (RedOrbit 2005). According to Exelon Corporation, while the construction of new natural gas combined-cycle power plants is the most economically viable option at the moment because of cheap natural gas prices, they are simply not required. This is because the current demand for electricity is low and many power markets are still saturated with generating capacity (Exeloncorp 2012).

As the state plans to phase out aging coal-fired power plants which we discussed in Section 2.2., there may be the need to operate underutilized natural gas plants to fill the lost capacity. As a relatively low carbon source of electricity compared to coal, natural gas emits 156 grams of carbon dioxide per one million calories burned natural gas, that is about one half of that of coal for the same calories (U.S. DOE 2010). Furthermore, burning natural gas would emit much less sulfur, mercury and particulate matter than coal.

Recent developments in high-temperature and more efficient natural gas combustion turbine (NGCT) plants by Mitsubishi Heavy Industries and natural gas combined cycle (NGCC) plant by General Electric, and Siemens could further help Illinois in switching to natural gas fired power plants in electric power production (Patel 2011) and reducing environmental pollution caused by coal fired power plants.

In 2011 the Mitsubishi Heavy Industries announced their J-Series natural gas combustion turbine (NGCT) with a claimed thermal efficiency exceeding $60 \%$ as the world's highest turbine inlet temperature of $1,600^{\circ} \mathrm{C}$.

Also in 2011, the General Electric Company launched its new natural gas combined cycle (NGCC) power plant known as FlexEfficiency-50. This new $510 \mathrm{~mW}$ power plant is claimed that it could start under 30 minutes with a push of a button and is capable of offering efficiency greater than $61 \%$.

In Germany, Siemens also announced setting a new world record in power plant efficiency by launching the SGT5-8000H natural gas combined cycle (NGCC) power plant. It is claimed this new generation H-class gas turbine is the result of ten years research effort and is 
capable of reaching over $60 \%$ of efficiency. This Siemens turbine was designed for $400 \mathrm{~mW}$ in simple-cycle duty and for $600 \mathrm{~mW}$ in combined-cycle duty (Patel 2011b).

Natural gas combustion turbine (NGCT) plant and natural gas combined cycle (NGCC) plant are the two categories of plants that burn natural gas and compressed air to produce steam and generate electricity (see Figure 13).

An example of an NGCT power plant operating already in Illinois is the 640-megawatt natural gas-fired Lee Energy facility located at approximately 145 kilometers (90 miles) west of Chicago, in Lee County, Illinois. The Lee facility is owned by Duke Energy and consists of eight $80 \mathrm{~mW}$ natural gas-fired combustion turbines, operating in simple-cycle mode (IEPA 2004).

An example of NGCC power plant operating already in Illinois is the Minooka combined cycle power plant in Kendall County in Illinois. The 1,160 mW facility owned by Dynegy Inc, consists of four-train GE 7FA combustion gas turbines with four three-pressure, reheat heat recovery steam generators and four GE steam turbine generators. The facility is duct-fired in the summer to boost power during local peak periods (SNC-Lavalin 2005).

The NGCC plant is generally more efficient than the NGCT plant because it makes maximum use of the energy in the fuel through a two-step generating process that captures waste heat that would otherwise be lost. The NGCC plants are typically operated to meet intermediate load demands, while the NGCT plants operate in peak-load shaving demand periods or much fewer operating hours. The NGCC plants may be constructed within two to three years at the cost of roughly $\$ 1,200$ per $\mathrm{kW}$ (Kaplan 2010), as opposed to coal-fired plants which takes five to six years at the cost of approximately $\$ 3,500$ per $\mathrm{kW}$. The annual operation and maintenance costs of NGCC and NGCT plants are estimated at $4 \%$ of the investment costs per year (Seebregts 2010). It is estimated that the levelized-cost of energy for the NGCC plant is between \$67-96 per megawatt (Mw) hour (Wernau 2011). The efficiency of NGCT plants is about 35-42\%, compared with 52-60\% for NGCC plants (Seebregts 2010).

There are certain factors that need to be dealt with in order to increase the likelihood of replacing coal with natural gas in Illinois. These include the amount of excess natural gas-fired generating capacity available in Illinois; the current operating patterns of coal and gas plants, the amount of flexibility power system operators may have for changing those patterns, and whether or not the transmission grid could deliver power from existing gas power plants to loads currently served by coal plants. Additionally, it is important to have sufficient natural gas supply 
pipeline and gas storage capacity to deliver large amounts of additional fuel to gas-fired power plants (Kaplan 2010).

However, due to the prevailing uncertainties about natural gas prices and $\mathrm{CO}_{2}$ emission tax that could rise in the future, it may be difficult to adopt any robust strategy for natural gas fired power plants in electric power production deployment in Illinois. This situation may result in a changing economic balance between gas and coal-fired power plants; unless Illinois can find a solution to exploit its shale-gas deposits in the Illinois Basin.

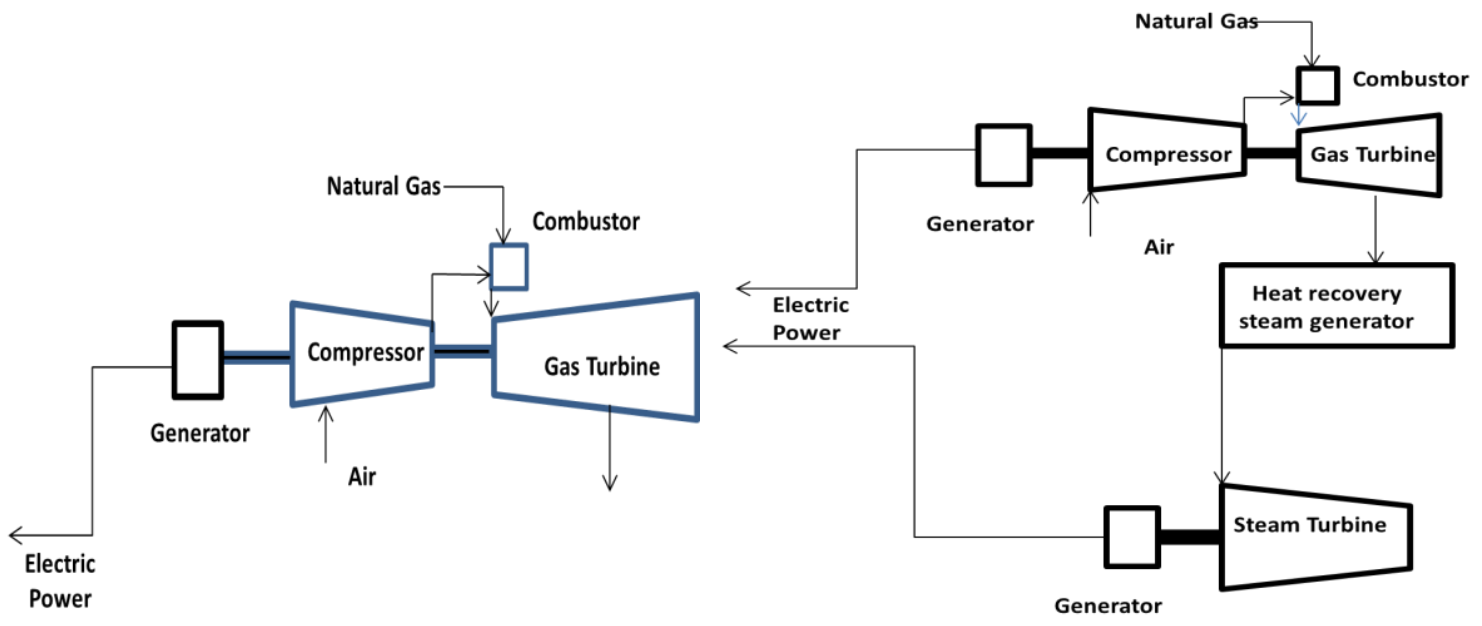

Figure 13. Principles of natural gas combustion turbine (NGCT) plant (left) and natural gas combined cycle (NGCC) plant (right) [US-EIA 2010].

\section{CARBON DIOXIDE CAPTURE AND SEQUESTRATION IN ILLINOIS}

Illinois ranks $6^{\text {th }}$ in carbon dioxide emission in the nation with the annual output estimated at about 190 million metric tons. The major emitters of carbon dioxide in the state are electric power plants followed by the transportation industry (see Table 11).

Reducing carbon dioxide released into atmosphere would reduce and reverse the global warming that we have been experiencing in the last several years. Although electricity generation using conventional coal-fired power plants is a matured industry, there remain several obstacles when connecting this conventional process with carbon dioxide capture technology. 
Among the obstacles are the high capital cost of carbon dioxide capture technologies (with approximately $75 \%$ increase in capital cost for adding carbon dioxide capture equipment), a large footprint required for carbon dioxide capture equipment, operational problems and a high energy penalty for carbon dioxide removal from flue gases in absorption columns by liquid solvents and regeneration of absorbing solvents.

Table 11. Illinois $\mathrm{CO}_{2}$ emissions (in metric tons) by source type in 2004 (Finley et al. 2010; US-EIA 2012)

\begin{tabular}{|l|r|}
\hline Industry sectors & $\mathbf{1 0}^{\mathbf{6}}$ tons \\
\hline Cement & 2.5 \\
\hline Chemical & 0.4 \\
\hline Compressor stations & 1.2 \\
\hline Electricity generation & 95.5 \\
\hline Ethanol plants & 7.6 \\
\hline Iron and steel & 3.5 \\
\hline Refineries & 9.3 \\
\hline Transportation & 68.8 \\
\hline All other & 1.7 \\
\hline Total & 190.5 \\
\hline
\end{tabular}

The majority of the post-combustion technologies for $\mathrm{CO}_{2}$ capture include passing the flue-gas through a packed bed absorber column, where the sorbent selectively absorbs the carbon dioxide. The carbon dioxide rich solvent then enters a regenerating column or stripper, where the $\mathrm{CO}_{2}$ is released through application of heat and the solvent is returned to the absorber. It is estimated that energy requirements for carbon dioxide capture and compression reduces the net plant power output by nearly 20 to 30\% (Phillips and Maxson 2011). Several methods have been designed with the view to optimizing the process and reducing the capital cost involved through the testing of new solvents.

The conventional approach for post-combustion carbon dioxide capture is the use of monoethanolamine (MEA) solvent. However, there are claims of development of advanced amine-based solvents (Mitsubishi Heavy Industries 2009; Brown et al. 2009) that could capture more carbon dioxide than MEA. 
Another post-combustion technology for capturing carbon dioxide is the use of chilled ammonia (Cerimele and McMillian 2011). In this process it is claimed the chilled concentrated ammonia solution would chemically bind the carbon dioxide, followed by application of heat to release the carbon dioxide for compression and storage. The flue-gas is chilled to about $2{ }^{\circ} \mathrm{C}$ before entering the absorber. In the absorber, ammonium carbonate, $\left(\mathrm{NH}_{4}\right)_{2} \mathrm{CO}_{3}$ and ammonia based-solvent absorb the carbon dioxide to form ammonium bicarbonate, $\mathrm{NH}_{4} \mathrm{HCO}_{3}$. Then the ammonium bicarbonate slurry is pumped to the regenerator to liberate the carbon dioxide and recover the ammonium carbonate for reuse. It is claimed the efficient operation of the process is ensured by heat recovery.

The initial demonstration of the later process took place at Wisconsin-Energy's power plant in Pleasant Prairie, Wisconsin on a $1.7 \mathrm{~mW}$ electric power plant's exhaust flue-gas stream. The process was reported to be capable of $90 \%$ carbon dioxide removal from a slipstream of the plant's flue-gas (Cerimele and McMillian 2011). The claimed environmental benefits using this technology included lower energy for carbon dioxide capture relative to other technologies, high removal of other pollutants such as sulfur trioxide and particulate matter of size $2.5 \mu \mathrm{m}$ and more.

In 2003, the Midwest Geological Sequestration Consortium (MGSC) was launched as a Phase I Department of Energy (DOE) Regional Carbon Sequestration Partnership, which continued in 2005 as a Phase II effort. The objective of the MGSC was to study the geological carbon sequestration potential in the Illinois Basin (Frailey \& Finley 2006). MGSC was headed by the Illinois State Geological Survey, in collaboration with Indiana and Kentucky Geological Surveys, and including a group of subcontractors. The results for this project are reported in the subsequent paragraphs.

Since Illinois is currently transitioning to clean-coal-technologies, adequate carbon dioxide sequestration infrastructure development will be the key to the success of this transition. In all carbon dioxide capture technologies the cleaned flue-gas, containing mainly nitrogen, oxygen and lower carbon dioxide concentration would flow to the stack, while the captured carbon dioxide would be transported to geologic storages. There are three types of subsurface formations in the Illinois Basin which have been identified for carbon dioxide storage. These are deep coal seams considered uneconomical for mining in the near future, depleted or mature oil and natural gas reservoirs, and saline aquifers containing non-potable water. 
As we discussed in Section 4.3., depleted or mature oil and natural gas reservoirs, and saline aquifers containing non-potable water are already used for natural gas storage in Illinois. It will be necessary to identify additional such geological sites for carbon dioxide sequestration.

Coal-seams that are too thin and laying deeper than about 300 meters underground and less than about $100 \mathrm{~cm}$ thick are considered to be technically and economically unminable, as compared to shallow and thick coal seams (Frailey and Finley 2006). These unminable coal seams in the Illinois Basin contain adsorbed methane gas that could be displaced using carbon dioxide, due to the high affinity of carbon dioxide to coal relative to methane. An estimated $566.34 \times 10^{9}$ standard cubic meters (20 Tscf) of methane is estimated to be trapped in the coal seams that cover Illinois and Indiana regions of the Illinois Basin (Leetaru et. al. 2006). At Saline County in Illinois, BPI Industries, owner of coal-bed methane (CBM) project has been selling gas produced from CBMs into pipelines (Oestreich \& Rodvelt 2005).

Injecting carbon dioxide into coal seams may boost natural gas production in Illinois to commercial levels. The carbon dioxide can be separated from the methane using membrane separation technology or formulated amine solvents depending on the outlet gas specification of the contactor (Agyarko 2005). Currently, carbon dioxide retention characteristics of coal seams are being studied as part of the DOE Regional Carbon Sequestration Partnership using new data from test wells. In the $2^{\text {nd }}$ column of Table 12, we present the $\mathrm{CO}_{2}$ storage resource in unminable coal areas in the Illinois Basin.

Table 12. $\mathrm{CO}_{2}$ Storage capacity of unminable coal areas, oil fields, saline formations and total per category in the Illinois Basin by state (Data from Finley et. al., 2010)

\begin{tabular}{|l|c|c|c|c|}
\cline { 2 - 5 } \multicolumn{1}{c|}{} & \multicolumn{3}{c|}{ CO2 storage capacity (10 ${ }^{6}$ metric tons) } \\
\hline State & $\begin{array}{c}\text { Unminable coal } \\
\text { areas }\end{array}$ & Oil fields & $\begin{array}{c}\text { Saline } \\
\text { formations }\end{array}$ & Total \\
\hline Illinois & $1,470-2,900$ & $106-358$ & $8,400-116,000$ & $9,976-119,258$ \\
\hline Indiana & $86-170$ & $20-47$ & $2,900-39,000$ & $3,006-39,217$ \\
\hline Kentucky & $68-134$ & $14-35$ & $400-5,600$ & $482-5,769$ \\
\hline 3-state total & $1,624-3,204$ & $140-440$ & $11,700-160,600$ & $13,464-164,244$ \\
\hline
\end{tabular}


As part of the DOE Regional Carbon Sequestration Partnership, a comprehensive evaluation of the oil fields in the Illinois Basin for carbon dioxide storage was carried out by the Midwest Geological Sequestration Consortium (MGSC). This evaluation was based on specific parameters of the oil fields, such as original-oil-in-place, porosity, and permeability, water saturation, in addition to temperature and pressure (Leetaru et al. 2006). In the $3^{\text {rd }}$ column of Table 12 we report the $\mathrm{CO}_{2}$ storage capacity in the depleted oil fields of the Illinois Basin.

Deep saline formations in the Illinois Basin are the other options for large scale carbon dioxide sequestration in Illinois. Because the water in these formations has depth ranging from 1,200-1,500 $\mathrm{m}$ and with two to three times the salinity of sea water, it is not drinkable (Leetaru $e t$ al. 2006).

An example of these formations is the Mt. Simon Sandstone which is a major saline reservoir lying below the oil reservoirs in Southeastern Illinois and Southwestern Indiana. The nature of the geology of the Mt. Simon sandstone makes it an ideal location for carbon dioxide storage. The Mt. Simon sandstone has a depth ranging from about 610 to 4,267 meters (approximately 2,000 to 14,000 feet) below the surface of earth (Finley et. al. 2010). Furthermore, the cap-rock seal of the Eau Claire Shale has demonstrated as an excellent seal for natural gas containment.

The St. Peter Sandstone may also be suitable for carbon dioxide sequestration. The St. Peter Sandstone is extended, porous, and permeable quartz sandstone which, in general, includes fine-grained with good lateral continuity. Above the St. Peter sandstone are seals made up of several hundred feet of dense limestone and dolostone overlain by about 46 to 76 meters (150 to 250 feet) of Maquoketa Shale (Finley et. al. 2010). But data for assessing the Mt Simon Sandstone in the Southern Illinois area is a major challenge. As a result, a comprehensive data compiled from studies of natural gas storage fields was used for the first time to assess the feasibility of the deep Mt. Simon sandstone in Southern Illinois for carbon dioxide sequestration (Leetaru et al. 2006).

The most widespread and prolific petroleum bearing sandstone in the Illinois Basin is the Cypress Sandstone. These areas with thick Cypress sandstone tend to have a large water bearing zone that may be considered a saline storage target for carbon dioxide. The porous and permeable sandstone is generally less than 30.48 meters (100 feet) thick and shows a significant variation in thickness and lateral extent, but it can also reach a thickness of 60.96 meters (200 
feet). The Cypress sandstone is the shallowest among the saline reservoirs examined in this project, with estimated depths approaching approximately 914.40 meters (3,000 feet) in some parts of the Illinois Basin (Finley et. al. 2010). The quantification of $\mathrm{CO}_{2}$ storage resource of these saline formations is presented in Table 13.

Table 13. $\mathrm{CO}_{2}$ Storage capacity of saline formations in the Illinois Basin by reservoir (Finley et. al. 2010)

\begin{tabular}{|c|c|}
\hline Reservoir & $\begin{array}{c}\mathrm{CO}_{2} \text { storage capacity } \\
\left(10^{6} \text { metric tons }\right)\end{array}$ \\
\hline Cypress Sandstone & $200-2,300$ \\
\hline St. Peter Sandstone & $600-7,800$ \\
\hline Mt. Simons Sandstone & $11,000-151,000$ \\
\hline Total & $12,000-161,000$ \\
\hline
\end{tabular}

In the $4^{\text {th }}$ column of Table 12 we report the storage capacity of saline formations in the Illinois Basin by state which is the sum of the data reported in Table 13.

In 2008, as part of the DOE Regional Carbon Sequestration Phase I project, the Midwest Geological Sequestration Consortium (MGSC) in conjunction with Archer-Daniels-Midland Company (ADM) in Decatur in Illinois and Schlumberger Carbon Services began a couple of projects to evaluate the safety and efficiency of carbon dioxide storage in the Illinois Basin (McKinney and Finley 2008).

The first project (Illinois Basin-Decatur project) confirmed that the saline-water-bearing Mount Simon Sandstone rock formation running below an ADM complex at Decatur in Illinois, is a suitable location for geologic carbon sequestration. Consequently, in November 2011, the project began injecting carbon dioxide into the Mount Simon sandstone formation at a depth of 2,135 meters below the ground (Kuipers 2011). The injected carbon dioxide is a byproduct from ADM's biofuels plant near the storage site in Decatur, Illinois. The Decatur experiment will continue injecting $\mathrm{CO}_{2}$ for the three years, and has drawn significant interest from other industrial and scientific countries around the world.

The second project is the Illinois-Industrial Carbon Capture and Sequestration project (IL-ICCS). This project aims to demonstrate the commercial-scale sequestration of carbon 
dioxide within the Mount Simon formation. The project is scheduled to begin carbon dioxide injection into the Mount Simon formation in the third quarter of 2013. The project consists of 2,000 metric tons per day compression/dehydration facility and a pipeline capable of transporting the carbon dioxide form ethanol plant to the sequestration and monitoring site (Hakun 2011, McDonald 2011).

The above-mentioned two projects will combine to inject a total of 3,000 tons of carbon dioxide per day when they become operational (McDonald 2011). Data from these projects are intended to provide baseline information for future development of carbon capture and sequestration opportunities not only for the Illinois Basin, but for the entire United States.

Apart from the DOE-funded project, in 2009, Denbury Resources, Inc. concluded a feasibility study on construction of the Midwest $\mathrm{CO}_{2}$ Pipeline. The purpose of this project was to assess information and data, regarding the possibility of creating an infrastructure to assist in the transportation of captured carbon dioxide. The captured carbon dioxide is expected to be transported from coal gasification plants in Illinois, Indiana and Kentucky to the Gulf Coast, for a safe and permanent underground sequestration through enhanced oil recovery operations (IDCEO 2010). More than 200 miles of the Midwest $\mathrm{CO}_{2}$ Pipeline would be located in Illinois, and will be linked with one or more of the proposed gasification projects to Denbury's existing pipeline network in the Gulf States. A project like this is expected to spur economic growth in the region.

\section{Conclusions}

Illinois currently consumes more fossil fuel than it produces. Therefore, for the state to become independent in fossil fuel consumption, it must explore alternative methods to increase their production.

It is estimated that Illinois has 250 years supply of indigenous coal, based on the current rate of coal consumption in the state (IDCEO 2008). But Illinois imports coal from other states because of the high sulfur content of the indigenous coal, coupled with surface developments, such as highways and buildings which prevents access to high quality coal. To circumvent these

problems and increase its coal production, the state is currently deploying clean coal 
technologies, such as oxy-combustion and coal-to-gas plants. These technologies claim they could handle the high sulfur content Illinois coal, while being in compliance with the new EPA emission rules. Another technology that could be considered in Illinois is underground coal gasification. This technology may boost the state's coal usage by making use of unminable coal seams or coal seams which access have been hampered by surface developments for several years and/or are mixed with oil which makes them unsafe for mining.

Currently, Illinois consumes more natural gas than it produces, requiring the state to import natural gas to make up for the shortage. But with the passage of Illinois senate bill (SB 0664) allowing hydraulic fracturing in the state, Illinois could increase its natural gas production in the near future to become independent in natural gas consumption, at least in the short term. This is achievable by tapping into the state's claimed vast resource of shale gas in the Illinois Basin estimated at $(2.44-4.53) \times 10^{12}$ standard cubic meters, as we mentioned in section 4.2.2 (US-GS 2007; Dahaghi \& Mohaghegh 2009). This could provide a steady gas supply with, possibly, guaranteed price to the state's gas-fired power plants for up to 40 years or more (OilGas-News 2011). Also, the estimated $(76.46-277.51) \times 10^{9}$ standard cubic meters of enhanced coal-bed methane potential in the Illinois Basin as we mentioned in section 4.1 may be tapped for domestic consumption in the near future, while coal would be converted in to more gas using coal-to-gas plants (Finley et. al. 2010).

Similar to natural gas, Illinois also consumes more petroleum every year than its current annual production. As a result, the state is considering the use of horizontal drilling and enhanced oil recovery techniques to harness the estimated 4.1 billion barrels of un-recovered movable oil in the state's oil reservoirs in the Illinois Basin. This current estimate of crude oil in Illinois Basin is about one half of its original volume in 1905, when oil was first discovered in Illinois. Therefore, based on the average annual petroleum oil consumption of Illinois which is estimated at 247.5 million barrels, the 4.1 billion barrels un-recovered movable oil in the state's portion of the Illinois Basin may last for up to 16 years (US-EIA 2011; IOGA 2011). This means that in the long term, it will be difficult for the state to become independent in petroleum oil consumption, without an alternative solution besides oil importation. An apparent solution to this problem will be the conversion of some the state's abundant coal resource into petroleum products using coal-to-liquid technology. 
Most of the clean coal technologies that are currently being deployed are already saddled with cost overruns. Furthermore, there are uncertainties about the long-term practicality and safety aspects of the proposed carbon capture and sequestration technology, the backbone of clean coal technology. These aspects include potential hazards, such as leakage of sequestered $\mathrm{CO}_{2}$ in to the atmosphere, or contamination of drinking water aquifers, as well as possible harmful induced geological instabilities. Obviously the "clean coal technology" deployment in Illinois would not pass the sustainability test. We have to wait and see if the plans and prospects for non-renewable energy sources that are discussed in this paper would meet a partial sustainability criteria. Thus considering the uncertainties surrounding the future of nonrenewable energy sources in Illinois, it is important that the state continue to add into its energy mix the renewable energy sources. This will improve the state's chances of finding a longer term solution toward the attainment of sustainability that includes energy independence and high quality environment.

Acknowledgements: The authors are thankful to many colleagues and friends and specially L.A. Curry, H. Ebneyousef, A. Esche, N. Enayati and A.F. Koster van Gross, M.M. Moayeri, and T. Wolf for their very helpful comments and encouragements. This self-supported research is dedicated to the people and the government of the State of Illinois.

\section{REFERENCES}

Affolter, R.H. and Hatch, J.R. (2002)'Characterization of the Quality of Coals from the Illinois Basin,' Chapter E, in Hatch, J. R., and Affolter, R.H., eds., Resource Assessment of the Springfield, Herrin, Danville, and Baker Coals in the Illinois Basin: U.S. Geological Survey Professional Paper 1625-D, 233 p. [CD-ROM]. (http://pubs.usgs.gov/pp/p1625d/Chapter_E.pdf)

Agyarko, L. (2005) 'Theoretical and experimental studies of the effect of $\mathrm{CO}_{2}$ on $\mathrm{H}_{2} \mathrm{~S}$ scavengers performance', MS thesis, The University of Illinois at Chicago, pp.1-45.

Andrea, A.T. (1886) 'History of Chicago: From the Earliest Period to the Present Time, 18711885', The A.T Andreas Company, Publishers, Chicago, vol.3, 755pages 
[ARI] Advanced Resources International. (2006) 'Basin Oriented Strategies for $\mathrm{CO}_{2}$ Enhanced Oil Recovery: Illinois \& Michigan Basins.U.S. Department of Energy-Office of Fossil Energy-Office of Oil and Natural Gas, Technical report, NTIS announcement issue: 0620, 108pages.

Arthur, J. D; Langhus, B and Alleman, D. (2008) 'Overview of modern shale gas development in the United States', All Consulting, vol.1, pp.1-21.

Arthur, J. D. and Seekins, J. (2010) 'Water and Shale Gas Development', proceedings of the National Association of Royalty Owners Annual Conference', $7^{\text {th }}$ October, Pittsburgh, PA., pp.1-39.

Barron, L. S. and Ettensohn, F. R. (1981) 'Depositional model for the Devonian-Mississippian

Black-Shale sequence of North America: a tectono-climatic approach', U.S. Dept., of Energy, DOE/METC/12040-2, pp.1-70.

Benmekki, E. H. and Mansoori, G. A. (1986) 'Accurate Vaporizing Gas Derive Minimum Miscibility Pressure Prediction', SPE Paper \# 15667, proceedings of the $61^{\text {st }}$ Annual Technical Conference and Exhibition of the Society of Petroleum Engineers, 5-8 October, New Orfeans, LA, pp.1-12.

Bond, D. C. and Buschbach, T. C. (1967) 'Underground storage of natural gas in Illinois', Illinois State Geological Survey, Illinois Petroleum, vol.86, p.54.

Bond, D. C. and Buschbach, T. C. (1973) 'Underground storage of natural gas in Illinois', Illinois State Geological Survey 'Illinois Petroleum', vol.101, p.80.

Bradshaw, J. B. and Dance, T. (2005) 'Mapping geological storage prospectivity of $\mathrm{CO}_{2}$ for the world sedimentary basins and regional source to sink matching', Proceedings of the $7^{\text {th }}$ International Conference on Greenhouse Gas Technologies (GHGT-7), 5-9 September, Vancouver, BC. vol.1, pp. 583-591.

Brown, J. H., Reddy, S. and Johnson, D. W. (2009) 'Commercially available $\mathrm{CO}_{2}$ capture', Power Magazine, vol.16, no.3, pp.1-3.

Buchan, B. and Cao, C. (2004) 'Coal-fired generation: proven and developing technologies', Office of Market Monitoring and Strategic Analysis, Florida Public Service Commission Reports and other sources: electric and gas, no.6, pp.1-25.

Carpentier, B., Wilhelms, A. and Mansoori, G. A. (2007) 'Reservoir organic geochemistry: Processes and applications', J. Petrol. Sci. \& Eng., vol.58, no’s.3-4, pp.341-343.

Cardott, B. J. (2008) 'Understanding gains on 'new' reservoir Shale Closing 'Conventional' Gap', AAPG Explorer, vol. 29, no. 11, p.78. 
Cerimele, G. L. and McMillian, M. H. (2011) 'Mountaineer Commercial Scale Carbon Capture and Storage Project', Topical Report: Preliminary Public Design Report, American Electric Power (AEP) Service Corporation and U.S. Department of Energy, DOE Award No: DE-FE0002673, pp.2-76.

Chiu, C.-H. and Newton, C. L. (1980) 'Second law analysis in cryogenic processes' Energy. vol.5, issues: 8-9, pp. 899-904.

[CIAB] Coal Industry Advisory Board (2010) 'Power Generation from Coal: Measuring and Reporting Efficiency Performance and CO2 Emissions', CIAB International Energy Agency ,Paris, Report: OECD/IEA2010, pp.1-114.

Coal Age (2011) 'Prairie State Energy Campus Startup Just a Few Months Away', Coal Age News, vol. 117, no.8, p.6.

Cluff, R. M., Shimf, N. F. and Bergstrom, R. E. (1980) 'Geologic and geochemical studies of the New Albany shale group (Devonian-Mississippian) in Illinois', University of Illinois/Illinois State Geological Survey, Annual Report: ORO-E-(40-1)-5203-12, pp.279.

Cluff, R. M. and Dickerson, D. R. (1982) 'Natural gas potential of the New Albany shale group (Devonian-Mississippian) in Southeastern Illinois', SPE Journal, vol.22, no.2, pp.291300 .

Cordaro, M. (2008) 'Understanding base load power: what it is and why it matters', New York Affordable Electricity Alliance (AREA), issue: 2008-7-10, pp.1-5.

Dahaghi, A. K. and Mohaghegh, S. D. (2009) 'Economic Impact of Reservoir Properties, Horizontal Well Length and Orientation on Production from Shale Formations: Application to New Albany Shale', SPE paper \# 125893, proceedings of the 2009 SPE Eastern Regional Meeting, 23-25 September, Charleston, WV, pp.1-11.

Dyer, P. N., Richards, R. E., Russek, S. L. and Taylor, D. M. (2000) 'Ion transport membrane technology for oxygen separation and syngas production', Solid State Ionics, vol.134, no's.1-2, pp.21-33.

Dow Jones Newswires. (2012) 'U.S. Court to Scrutinize EPA's Delayed Power Sector Rule', Fox Business, vol.2012, issue: 2012-4-2, pp.1-4.

Drajem, M. (2011) 'EPA Issues Air Toxics Cap for U.S. Coal-Fired Power Plants', Bloomberg Business Week, vol. 2011, issue: 2011-12-21, p.6.

Durham, L. S. (2010) 'Illinois Basin Shale gets tech focus', AAPG Explorer, vol.31, no.3, p.38. Edalat, M. and Mansoori, G. A. (1988) 'Buried Gas Transmission Pipelines', Energy Sources Journal', vol.10, no.4, pp.247-252. 
Energy Justice and Network. (2012) 'Fuels and Technologies: Coal: Dangerous Power', Energy Justice and Network, vol.3, no.1, pp.1-5.

Environmental Engineering Solutions. (2008)' High performance Coal-fired 'Supercritical Power plants'-Promotes cleaner environment', Environmental Engineering Solutions vol.2, no.15, pp.1-23.

Environmental News Service. (2006) 'Ameren to slash emissions at Illinois coal-burning power Plants', Environment News Service. vol.2006-8, no.36, pp.1-4.

Evans, D. J. and West, J. M. (2008) 'An appraisal of underground gas storage technologies and incidents, for the development of risk assessment methodology', British Geological Survey, Open Report, OR/07/023, pp.1-57.

Exeloncorp.(2012) 'A diverse portfolio of responsible coal, oil and natural gas generation: Fossil Investment' (www.exeloncorp.com/energy/generation/fossil.aspx) 17 pages.

[FERC] Federal Energy Regulatory Commission (2004) 'Current state of and issues concerningunderground natural gas storage', Federal Energy Regulatory Commission2004, Washington, DC, Docket no.AD04-11-000, pp.2-33.

Finley, R. J. (2011) 'Illinois in the Global Energy Marketplace', Illinois State Geological Survey, Prairie Research Institute, Short Technical Topics, no.5, pp.1-7.

Finley, R.J., Greenberg, S.E. and Frailey, S.M. (2010) 'Midwest Geological sequestration consortium', in 2010 Carbon Sequestration Atlas of the United States and Canada, DOE/NETL, Third Edition (Atlas III), pp.48-59.

Finley, R.J (2007a) 'First Geological Sequestration-Enhanced Oil Recovery Field Test Among Department of Energy Regional Carbon Sequestration Partnerships Takes Place in the Illinois Basin', Illinois Oil and Gas Association, vol.57, no.2, pp.1-12.

Finley, R. J. (2007b) 'Field test overview, and Assessment of the geological carbon sequestration options of the Illinois Basin', Sixth Annual DOE Conference (www.netl.doe.gov/publications/proceedings/07/carbon-seq/data/papers/RobertFinley.pdf).

Flores, M., Colgan, J., Ford, L., Elliot, S. and O'Connell-Diaz, E. (2010) 'Analysis of the Taylorville Energy Center Facility Cost Report', Illinois Commerce Commission (ICC), TEC Report no.1, pp.1-45.

Folger, P (2009) 'Carbon Capture and Sequestration (CCS)', Congressional Research Service, CRS Report no.RL33801, pp.1-31.

Frailey, S. M. and Finley, R. J. (2006) 'Site screening and assessment for testing geological sequestration in the Illinois Basin: An assessment of options in the Illinois Basin: A DOE 
phase II Rregional partnership program', proceedings of the $\mathrm{CO}_{2}$ Symposium, Lawrence Berkeley National Laboratory, 20-22 March, Berkeley, CA, pp.1-28. .

Friedmann, S. J (2009) 'Coal without carbon: Accelerating Development of Underground Coal Gasification’, Clean Air Task Force, Lawrence Livermore National Laboratory, vol.2, no.37 pp.1-17.

Gharbi, R. B. C. and Mansoori, G. A. (Ed's) (2005) 'Artificial Intelligence Applications in Petroleum Exploration and Production, A special Issue, J. Petroleum Science \& Engineering, vol.49, No's.3-4, pp.93-280.

Glaser, R.R., Johnson, L.A and Western Research Institute (1986) 'Physical simulations of underground coal gasification in eastern bituminous coal', University of Wyoming Research Corp., Laramie, Western Research Inst., Report: DOE/FE/60177-2249, pp.1-14.

Global CCS Institute. (2009) 'Strategic Analysis of the Global Status of Carbon Capture and Storage Report 2, Economic Assessment of Carbon Capture and Storage Technologies', Global CCS Institute, Canberra, Australia, Final Report, pp.1-175.

[GRI] Gas Research Institute (1994) 'Gas Potential of the New Albany Shale (Devonian and Mississippian) in the Illinois Basin', Final Report, Illinois Basin Consortium, and Gas Research Institute, Report no.GRI-92/0391/ ILLINOIS B ASIN STUDIES 2, pp.1-83.

Grant, T. (editor) (2007) 'International Directory of Company Histories', Gale virtual reference library (ebook), St. James Press, Chicago, vol.14, ISBN:9781558623422.

[GTI] Gas Technology Institute (2009) 'New Albany Shale Gas Project', A Joint Industry Project Sponsored by Research Partnership to Secure Energy for America (RPSEA), Annual Progress Report, GTI Project no.20747, RPSEA Project no.07122-16, pp.1-114.

Grossman, I. (2011) 'Question of the Month July/August 2011: How much Canadian oil and gas are imported into the Midwest', The Midwestern Office of Council of State Governments, Stateline Midwest, vol.20, no.7, pp.1-12.

Hakun, J. (2011) 'Large-Scale Industrial Carbon Capture, Storage Plant Begins Construction', DOE's Office of Fossil Energy, news release no.2011/110824, pp.1-2.

Hamad, E. Z. (2006) 'Design of Ionic Liquid Solvents for Extractive Desulfurization' Proceedings of the 2006 Annual AIChE Meeting. November 12th-17th, 2006, San Francisco, California

Hammesfahr, F. W. and Winter, P. L. (1983)'Underground coal gasification: The leading source for lower-priced gas', Proceedings of the Ninth Annual underground coal gasification symposium, 7-10 August, Bloomingdale, IL, pp.68-74. 
Hawthorne, M. (2010) 'EPA targets coal-fired power plants: New rule would cut smog, soot in Chicago, nationwide', Chicago Tribune, vol.2010, issue.2010-07-07, pp.1-2.

Howarth, R. W., Anthony, R. S. and Ingraffea, A. (2011) 'Methane and the greenhouse-gas footprint of natural gas from shale formations', Climatic Change letter, Springer, DOI: 10.1007/s10584-011-0061-5, pp.1-12.

[IEA] International Energy Agency (2008) 'Energy Technology Perspectives 2008-Scenarios and Strategies to 2050, in support of the G8 Plan of Action', International Energy Agency (IEA), Paris, France, ISBN 978-92-64-04142-4, pp.1-650.

[IEA] International Energy Agency (2010) 'Gas-Fired Power', Energy Technology System Analysis Programme (IEA-ETSAP), Agency Energy Technology Network, IEA ETSAPTechnology Brief E02, p.1.

[IEA] International Energy Agency (2011) 'Clean Coal Technologies (CCT)', IEA Clean Coal Center, London, U.K., 2010-database-section, no’s.1-33, pp.1-2.

[IDCEO] Illinois Department of Commerce and Economic Opportunity (2008) 'The Illinois Coal Industry', Report of the Office of Coal Development, June 2008 Report, pp.1-75.

[IDCEO] Illinois Department of Commerce and Economic Opportunity. (2009) 'Prairie State Energy Campus \& Lively Grove Mine’, Office of Coal Development FY 2009 Annual Report, No.6, pp.1-2.

[IDCEO] Illinois Department of Commerce and Economic Opportunity (2010) 'The Illinois coal Industry', Report of the office of Coal Development, June 2010 Report, pp.1-31.

[IEPA] Illinois Environmental Protection Agency.(2004) 'Fossil Fuel-Fired Power Plants', Report to the House and Senate Environment and Energy Committees, IEPA/BOA/04020 , pp.1-115.

[IEPA] Illinois Environmental Protection Agency (2011) ' 4 th Illinois Annual Air Quality Report', State of Illinois, Report 2010, pp.1-105.

[IOGA] Illinois Oil and Gas Association (2009) 'The Oil and Gas Industry in the Illinois economy', RCF Economic and Financing Consulting, Inc, Regional Economic Application Laboratory (REAL) at University of Illinois, Urbana-Champaign, Executive Summary, IOGA Final Report no.Mar 4-09, pp.1-218.

[IOGA] Illinois Oil and Gas Association (2011) 'Oil and Gas Industry in the Illinois Economy', Illinois Oil and Gas Association, IOGA-Brochure-1, pp.1-10.

Jasmine (2009) 'The many problems with clean coal', Care2, Environment and wildlife causes, vol.2009, issue: 2009-2-10, pp.1-2. 
Jikich, S., Grube., J., Seyler, B., Webb, N and Damico, J. (2012).'Illinois Basin Applications Demonstrating Potential Of ASP EOR Technology', The American Oil and Gas Reporter, vol.2012, Issued:2012-06, pp.1-10.

Kalantari-Dahaghi, A. and Mohaghegh, S. D. (2011) 'A new practical approach in modeling and simulation of shale gas reservoirs: application to New Albany Shale', Int. J. Oil, Gas and Coal Technology, vol.4, no.2, pp.104-133.

Kaplan, S. M. (2010) 'Displacing coal with generation from existing natural gas-fired power Plants', CRS Report for Congress, no.R41027, pp.1-30.

Kling, G. W., Evans, W. C., Tanyileke,G., Kusakabe, M., Ohba, T., Yoshida,Y. and Hell, J. V. (2005) 'Degassing Lakes Nyos and Monoun: Defusing certain disaster', Proceedings of the National Academy of Sciences (PNAS), vol.102, no.40, pp.14185-14190.

Kuipers, D. (2011) 'Illinois sequestration project is first in U.S. for man-made $\mathrm{CO}_{2}$ ', Los Angeles Times, Greenspace, vol.2011, Issue: 2011-11-30, pp.1-2.

Lazar, O. R. and Schieber, J. (2004) 'New Albany and Ohio Shales: An Introduction: In Devonian Black Shales of the Eastern U.S.: New Insights into Sedimentology and Stratigraphy from the Subsurface and Outcrops in the Illinois and Appalachian Basins. Field Guide for the 2004 Great Lakes Section SEPM Annual Field Conference, J. Schieber and O. R. Lazar (editors), Indiana Geological Survey Open File Study 04-05, pp.31-34.

Learner, H. and Rowe, J. (2011) 'Clearing the air: when opposites actually agree in search of cleaner air’, Chicago Tribune. vol.2011, issue: 2011-05-13, pp.1-2.

Lee, S.D.W. (2011) 'Morgan County wins 1.3 billion dollars FutureGen clean coal project', Illinois Statehouse News, vol.2011, issue: 2011-03-01, pp.1-2

Leetaru, H.E., Gustison, S. R. and Finley, R. J. (2006) 'Geological consideration for $\mathrm{CO}_{2}$ sequestration in a cratonic basin: an assessment of options in the Illinois basin', Illinois State Geological Survey, DOE Contract no.DE-FC25-03NT41994, pp.1-5.

Lewis, J. and Bergeron, L. (2010) 'The Economic Impacts of the Energy Industry in Illinois', Regional Development Institute, Northern Illinois University, Dekalb, Illinois ISCC Energy Industry Report no.7-12-2010, pp.3-40.

Lopes Barros de Araujo, P., Silvano de Araujo, E. and Mansoori, G.A. (2012). 'Diamondoids: occurrence in fossil fuels, applications in petroleum exploration and fouling in petroleum production. A review paper' Int. J. Oil, Gas and Coal Technology, Vol.5, no.4, pp.316367. 
Lundy, D. and Salmi, H. (2012) 'Illinois EPA Issues Taylorville Energy Center Final Air Permit; Slashes Mercury Emissions Following Request by Tenaska',MoneyWatch, Wall Street Journal, Press Release, Issued: 2012-4-30. pp.1.

Lydersen, K. (2012). 'Ohio towns have buyer's remorse over Prairie State Energy Campus', MidWest Energy News, vol.2012, Issued:2012--07-09, pp.1-5.

Mahajan, D., Taylor, C. E., and Mansoori, G. A. (2007) 'An introduction to natural gas hydrate/clathrate: The major organic carbon reserve of the Earth', J. Petrol. Sci. \& Eng., vol.56, no's.1-3, pp.1-8.

Mansoori, G.A. (Editor) (1993) 'Proceedings of the $1^{\text {st }}$ International Non-Renewable Energy Sources Congress (INRESC)’ December 1993, 979 page.

Mansoori, G. A. and Edalat, M. (1996) 'Storage of Natural Gas in Liquids', Proceedings of the $5^{\text {th }}$ World Congress of Chemical Engineering, 14-18 July, San Diego, CA.

Mansoori, G.A. (Editor) (1998) 'Proceedings of the $2^{\text {nd }}$ International Non-Renewable Energy Sources Congress (INRESC)’ December 1998, 1,100 page.

Mansoori, G.A. and Moradi, A. (Editors) (2000) 'Selected paper from the Proceedings of the $2^{\text {nd }}$ International Non-Renewable Energy Sources Congress (INRESC)' Journal of Petroleum Science and Engineering, Volume 26, Issues 1-4, May 2000.

Martin, J. W., Byrer, C. W., Brummert, A. C and Wieber, P. R. (editors)(1983) 'Potential for Development of underground coal gasification in the bituminous coal resource', Proceedings of the Ninth Annual underground coal gasification symposium, 7-10 August 1983, Bloomingdale, IL, Report no's.DOE/METC-84-7; CONF-830827, pp.1-571.

Mastalerz, M., Drobniak, A., Rupp, J., Strąpoć, D., Schimmelmann, A. and Hasenmueller, (2010) 'Constraints on the origin and volume of gas in the New Albany Shale (Devonian Mississippian Eastern Illinois Basin', proceedings of the Eastern Section American Association of Petroleum Geologists (AAPG) conference, 25-29 September, Kalamazoo, MI. vol.94, pp.1713-1740.

McDonald, D.K; Moorman, S; Darde, A; and de Limon, S. (2011) 'Oxy-Combustion: A Promising technology for coal-fired plants'. Power Magazine, vol.9, no.3, pp.1-5.

McDonald, D.K. and Sturm, E.(2012) 'FutureGen 2.0: Oxy-coal's Opportunity' Technical Paper, BR-1853, Presented to: 36th International Technical Conference on Clean Coal \& Fuel Systems, 5-9June, Clearwater, Florida, FL.

McDonald, S. (2011) 'Q\&A with Scott McDonald', 2011 Corporate responsibility report, Archer Daniels Midland Company (ADM), Decatur, Illinois. Report no.2011CR, pp.1-2. 
McKinney, J. and Finley, R. J. (2008) 'ADM, MGSC and ISGS announce carbon Sequestration project', Archer Daniels Midland Company, Illinois State Geological Survey, ADM News Release, vol.3, issue: 2008-04-1, pp.1-2.

[MGSC]. Mid-West Geological Sequestration Consortium (2011) 'Enhanced oil recovery: EOR I pilot-Loudon Oil Field (Huff 'n Puff)', U.S. Department of Energy, award number DEFC26-05NT42588, Illinois Department of Commerce and Economic Opportunity, (www.sequestration.org/mgscprojects/loudon.html).

Mitsubishi Heavy Industries (2009) 'KM-CDR Post-Combustion $\mathrm{CO}_{2}$ Capture with KS-1'TM Advanced Solvent', proceedings of the Eight Annual Conference on Carbon Capture and Sequestration, May, Pittsburg, PA, pp.1-29.

Morse, D. and Huff, B. (1999) '3-D Modeling of Mt. Simon gas storage fields could enhance winter gas availability from the Illinois', DOE Fossil Energy Techline, vol.1999, issue no.1999-11.01, pp.1-2.

Nicolas, M. P. B. and Bamburak, J. D. (2009) 'Geochemistry and Mineralogy of Cretaceous shale, Manitoba (parts of NTS 62C, F, G, H, J, K, N): preliminary results', in Report of Activities 2009, Manitoba Innovation, Energy and Mines, Manitoba Geological Survey, pp.165-174.

Oestreich, R. G. and Rodvelt, G. D. (2005) 'Case History: First Commercial Illinois Coal Bed Methane Commences via a Structured Resource Evaluation Plan', In SPE paper \# 97720, proceedings of the SPE Eastern Regional Meeting, 14-16 September 2005, Morgantown, W V, pp.1-18.

Oil-Gas-News. (2011) 'New Albany Shale gas play, Illinois Basin', Oil-Gas-News, vol.2011, pp.1-2.

Palmer, M. A., Bernhardt, E. S., Schlesinger, W.H., Eshleman, K.N., Foufoula-Georgius, E., Hendryx, M.S, Lemly, A.D., Likens, G.E., Loucks, O.L., Power, M.E., White, P.S, and Wilcock, P. R. (2010) 'Mountaintop Mining Consequences', Science, vol.327, no.5962, pp.1-8.

Paktinat, J. and Mansoori, G. A. (1993) 'Reduction of formation damage, emulsion and adsorption through the use of ethoxylates in sandstone', Proceedings of the $1^{\text {st }}$ International Non-Renewable Energy Sources Congress (INRESC '93), M. Edalat and G. A. Mansoori (editors) pp.167-180.

Park, S. J., Kwak, T. Y. and Mansoori, G. A. (1987) 'Statistical Mechanical Description of Supercritical Fluid Extraction and Retrograde Condensation', International Journal of Thermophysics, vol.8, no.4, pp.449-471.

Patel, S. (2010a) ‘China: A world Powerhouse’, Power Magazine, vol.8, no.4, pp.1-6. 
Patel, S. (2010b) 'Resurrection of underground coal gasification', Power Magazine, vol.13, no.10 pp.1.

Patel, S. (2011) 'Pushing the 60\% Efficiency Gas Turbine Barrier', Power Magazine, vol.7, no.6, pp.1-3.

Pearcy, M; Ingraham, D; Lewis, R; Frantz, J; Sawyer, W and Williamson, J. (2004) 'New Evaluation Techniques for Gas Shale Reservoirs', proceedings of 2004 Schlumberger Reservoir symposium, pp.1-11

Peckham, J. (2009) 'Indiana UCG Studies Could Encourage New Projects', Hart Energy Publishing, vol.XII, no.8, pp.1-5.

Pekin Times (2011) 'Pekin has worst sulfur dioxide air pollution in state', Pekin Daily Times. vol.2011, Issue: 2011-05-19, p.1.

Phillips, J. and Maxson, A. (2011) 'Research and development for future coal generation', Power Magazine. vol.7, no.2, pp.1-4.

Probasco, D. and Ruhlman, B. (2011) 'Coal-Fired Generation Cost and Performance Trends', Power Magazine. vol.7, no.5, pp.1-5.

Purget, R; Shingledecker, J. and Viswanathan, R. (2011) 'Evaluating materials technology for advanced ultrasupercritical coal-fired plants', Power Magazine, vol.1, pp.1-3.

RedOrbit (2005) 'Peaker Plants Return, for the Moment Controversial Power Plants Struggle After Being All the Rage', RedOrbit, vol.2005, issue:2005-9-12, pp.1-3.

Reece, E. (2006) 'Moving Mountains: The battle for justice comes to the coal fields of Appalachia, Orion magazine, issue: January/February, pp.1-8.

Rice, G. S., Hood, O. P. et al. (1913) 'Oil and Gas wells through workable coal beds', U.S Department of Interior Bureau of Mines, Petroleum technology vol.7, Bulletin 65, pp.5101.

Schill, J. (2009) 'Natural gas storage field expansion uses static pipe bursting', Pipeline \& Gas Journal, vol.236, no.5. p.54.

Schor, T and Foy, J. (2012) 'Strategic American Oil Begins Water Injection in Its Illinois Waterflood Project', Duma Energy Corp., vol.2012, Issued:2012-02-13, pp.1-2.

Seebregts. A.J. (2010) 'Gas-Fired Power', Energy Technology System Analysis Programme (IEA-ETSAP), Agency Energy Technology Network, IEA ETSAP-Technology Brief E02, p.1. 
Sigmon, W. L. (2008) 'The lure of ultra-supercritical: Exploring the future of coal-burning', Energybiz Magazine, vol.5, no.5, pp.90-91.

Smith, M. B. and Montgomery, C.T. (2010) 'Hydraulic fracturing: history of enduring technology', Hydraulic Fracturing: History of an Enduring Technology." Journal of Petroleum Technology (Society of Petroleum Engineers), vol.62, no.12, pp.26-32.

SNC-Lavalin (2005) 'Minooka Combined Cycle Power Plant', Surveyer, Nenniger \& Chenevert Consulting Engineers, SNC-Lavalin Group Inc. no.WASH-0068-EN -2005, p.1.

Snow, N. (2012) ' DOE reports EOR success at Lawrence field in Illinois', Oil \& Gas Journal', vol. 2012, Issued: 2012-04-26, vol.2012, pp.1.

[SPEA] School of Public and Environmental Affairs (2011) 'Viability of Underground Coal Gasification with Carbon Capture and Storage in Indiana', Indiana University, A capstone course no.V600, Spring 2011, pp.1-175.

SRI Consulting. (2009) 'Disruptive Technologies-Global Trend 2025 - Clean coal technologies (Background)', SRI Consulting Business Intelligence, Appendix D, pp.1-9

Stevenson, D. L; Whiting, L. L; Cluff, R.M. (1981) 'Geologic structure of the base of the New Albany Shale Group in Illinois', Illinois State Geological Survey, Illinois Petroleum, vol.121, p.2.

Suwono, A. and Mansoori, G.A. (Editors) (1994, 1997, 2000, 2003, 2006) 'Proceedings of Fluid and Thermal Energy Conversion (FTEC) Conferences' (www.uic.edu/labs/trl/ftec.home/)

Taleghani, A. D. and Lorenzo, J. M. (2011) 'An Alternative Interpretation of Microseismic Events during Hydraulic Fracturing', SPE Paper \# SPE140468-PP, proceedings of the SPE Hydraulic Fracturing Technology Conference and Exhibition', 24-26 January, Woodlands, TX, pp.1-11.

Thorner, N. (2011) 'New EPA regs. for coal-fired plants are economy busters in Illinois', Illinois Review. issue: 2011-08-24, pp.1-6.

Tobin, J. (2006) 'Underground Natural Gas Storage, Developments: 1998-2005', U.S. Energy Information Administration, Office of Oil and Gas, DOE/EIA-0131, pp.1-16.

Touba, H. and Mansoori, G. A. (1998) 'Structure and Property Prediction of Sub- and Supercritical-Water', Fluid Phase Equilibria, vol.150-151, pp.459-468.

Touba, H., Mansoori, G. A., and Matteoli, E. (1998) 'Subcritical and Supercritical Water Radial Distribution Function', Int'l J. of Thermophysics, vol.19, no.5, pp.1447-1471.

Tyrpak, S and Livingston, R. (2012) 'Oil and Gas Companies Set Sights on Southern Illinois', WSILTV, issue: 2012-03-13, pp.1-2. 
Union of Concerned Scientist.(2010) 'Burning coal, burning cash: Illinois dependence on imported coal', Union of Concerned Scientist, States fact sheets, no.7, pp.1-2.

Urbina, I. (2011) 'Insiders sound an alarm amid natural gas rush', The New York Times, vol.2011, Issue: 2011-06-26, pp.1-6.

[US-DOE] U.S. Department of Energy (2006) 'Benefits of Demand Response in Electricity Markets and Recommendations for Achieving Them. A report to the United States Congress Pursuant to Section 1252 of the Energy Policy Act of 2005', U.S. DOE, 26 February, pp.2-93.

[US-DOE] US Department of Energy.(2010) 'FutureGen Industrial Alliance Announces Carbon Storage Site Selection Process for FutureGen 2.0', National Energy Laboratory Technologies database, News Release, Issued:2010-10-6, pp.1.

[US-DOE] U.S. Department of Energy (2011) 'Transmission Distribution and Storage: Investigating New Ways to Store Gas', DOE Fossil Energy Office of Communications, vol.2009, Issue: 2009-01-23, pp.1-5.

[US-EIA] U.S. Energy Information Administration (1994) 'State Coal Profiles: Illinois', Energy Information Administration, DOE/EIA-0576, pp.1-137.

[US-EIA] U.S. Energy Information Administration (2006) 'Underground Natural Gas Storage, Developments: 1998-2005’, Office of Oil and Gas October 2006. DOE/EIA-0131, pp.116.

[US-EIA] U.S. Energy Information Administration (2010) 'Updated capital cost estimates for electricity Generation Plants', Energy Information Administration Independent Statistical Analysis, Report no.AEO2011 cycle, pp.2-188.

[US-EIA] U.S. Energy Information Administration, (2011) 'State Energy Data System: Illinois', Independent Statistics and Analysis, Technical Notes and Documentation. Data Release Date: 2011-06-20.

[US-EPA] U.S. Environmental Protection Agency (2010) 'Science in Action: Hydraulic fracturing research', U.S. Environmental Protection Agency, Office of Research and Development (www.epa.gov/safewater/uic/pdfs/hfresearchstudyfs.pdf).

[US-EPA] U.S. Environmental Protection Agency (2011) 'Electrostatic Precipitator Operation', U.S. Environmental Protection Agency (http://findpdf.net/pdf-viewer/ElectrostaticPrecipitator-Operation-Environmental-Protection-Agency.html).

[US-GS] U.S. Geological Survey (2007) 'Assessment of Undiscovered Oil and Gas Resources of the Illinois Basin, 2007', National Assessment of Oil and Gas Fact Sheet, U.S. Department of Interior, Fact sheet: 2007-3058, pp.1-2. 
[US-DOJ] U.S. Dept. of Justice (1909) 'United States of America, Petitioner, V. Standard Oil Company of New Jersey et al. Defendants', Government Printing Office, Washington, D.C. vol 17. p.3481.

[US-HR] U.S. House of Representatives (2011) 'Chemicals used in hydraulic fracturing', U.S. Congress, Washington, D.C., Report no.2011-04, pp.1-32.

Wells, L. (2011) 'Southern Illinois coal-gasification plant will bring hundreds of jobs', Evansville Courier \& Press. vol.2011, issue: 2011-8-3, pp.1-2.

Wernau, J. (2011) 'Illinois options for replacing coal-fired power plants', Chicago Tribune. vol.2011, issue: 2011-06-17, pp.1-3.

Wernau, J. and Karp, G. (2011) 'Quinn signs bill opening door to Southeast Side coal-to-natural gas plant', Chicago Tribune, vol.2011, issue: 2011-06-13, pp.1-2.

Wilson, J. T. (2012) 'Imperial Begins Leasing Program in the Illinois Basin', Imperial Petroleum Inc., Issue: 2012-4-18, pp.1-2.

[WNA] World Nuclear Association (2011) 'Clean coal technologies, carbon capture and Sequestration', World Nuclear Association, Public Information Service Database: Climate Change and Sustainability Development, vol.7, no.1, pp.1-9.

Yeagle, P. (2011) 'Coal gasification plant approved by Senate: Proponents, critics at odds over need for Taylorville project', Illinois Times, vol.2011, Issue: 2011-12-8, pp.1-2. 